FACULDADE DE ARQUITETURA E URBANISMO

UNIVERSIDADE DE SÃO PAULO

MARINA CARAFFA

Projeto de assentamento rural. Um estudo sobre o ambiente construído no Zumbi dos Palmares - Iaras/SP

SÃO PAULO

Fevereiro de 2014 


\section{Projeto de Assentamento rural. Um estudo do ambiente construído no Zumbi dos} Palmares - Iaras/SP

Dissertação apresentada para obtenção do título de mestre do curso de Arquitetura e Urbanismo da Universidade de São Paulo. Nível: mestrado

Área de Concentração: Habitat

Orientadora: Prof. ${ }^{\text {a }}$ Dr ${ }^{\text {a }}$. Maria de Lourdes Zuquim.

SÃO PAULO 
AUTORIZO A REPRODUÇÃO E DIVULGAÇÃO TOTAL OU PARCIAL DESTE TRABALHO, POR QUALQUER MEIO CONVENCIONAL OU ELETRÔNICO, PARA FINS DE ESTUDO E PESQUISA, DESDE QUE CITADA A FONTE.

E-MAIL DA AUTORA: mcaraffa@gmail.com

Caraffa, Marina

C258p Projeto de assentamento rural. Um estudo do ambiente construído no Zumbi dos Palmares - Iaras/SP / Marina

Caraffa. -- São Paulo, 2014. 171 p. : il.

Dissertação (Mestrado - Área de Concentração: Habitat) FAUUSP. Orientadora: Maria de Lourdes Zuquim

1.Arquitetura 2.Assentamento rural 3.Assentamento -

Zumbi dos Palmares - Iaras (SP) I.Título 
Projeto de assentamento rural. Um estudo sobre o ambiente construído no Zumbi dos Palmares - Iaras/SP

Dissertação apresentada para obtenção do título de mestre do curso de Arquitetura e Urbanismo da Universidade de São Paulo. Nível: mestrado

Área de Concentração: Habitat

Orientadora: Prof. ${ }^{a}$. Dr ${ }^{\mathrm{a}}$. Maria de Lourdes Zuquim.
Data de aprovação:

Banca Examinadora:

Prof. . . Dra . Maria de Lourdes Zuquim (orientadora) 
Dedico este trabalho aos meus pais, Leo Caraffa e Rubia Mara Nascimento, às minha irmãs Gabriela e Valentina e ao meu marido Ramon Tavares, por tudo e por todos os anos. 


\section{AGRADECIMENTOS}

À minha orientadora Maria de Lourdes Zuquim, exigente e firme, me deu toda a força que precisei para chegar aqui.

À FAPESP, pela concessão da bolsa e oportunidade da dedicação exclusiva.

Aos meus pais, Leo e Rubia, à minha avó Cida, às minhas irmãs Gabriela e Valentina, à pequena Violeta e ao Ramon pelo amor, por tudo e por todos os anos.

Ao professor Eduardo Cusce, nobre pelas contribuições e questionamentos no exame de qualificação. À Maria Lucia Zoega, que me acompanhou com muito café, histórias e carinho na reaproximação com a gramática e à língua portuguesa. À professora Marta Inês de Medeiros Marques que me recebeu na Faculdade de Geografia da USP. Ao professor Nilton Ricoy Torres, pelo primeiro contato com a pós-graduação da FAUUSP como aluna especial. À Silvia Cayubi Novaes que ouviu as minhas primeiras questões e me incentivou a seguir adiante, e à Sanny Silva da Rosa que deu a mão na reta final.

Especialmente ao professor Silvio Soares Macedo que me recebeu como estagiária do Programa de Aperfeiçoamento de Ensino - PAE e muito contribuiu com minha experiência acadêmica.

À amiga companheira de vida, trabalho e pesquisa, Ciça, sem você teria sido mais difícil. Às pesquisadoras Roberta, Ana Júlia, Liliana e Ariella, pelo apoio e incentivo nas horas mais duras.

Aos funcionários da FAU USP, aos colegas do laboratório de paisagismo - QUAPÁ e do CESADE.

Aos amigos da vida, do trabalho e da vida acadêmica Fabiana, Rafael, Isabel, Teca, Camila França, Amanda, Aninha, Rodrigo, Chris, Mayra, Denise, Bia, Flávia, Katna, Nicole, Brenda e Joyce que, mesmo a distância, estiveram ao meu lado.

Aos meus sogros, José Augusto e Eurídice.

Ao Ramon que, com muito amor e paciência, me ajudou a chegar ao fim. 
O papel do geógrafo (seja qual for seu diploma) é "espacializar" as transformações sociais. Entender o espaço é entender como ele participa das transformações sociais e como com elas interage. Não existe transformação social sem a participação do espaço, e não existe a transformação do espaço sem a transformação social.

\section{Flávio Villaça}




\title{
Resumo
}

A dissertação trata do estudo do projeto de assentamento rural enquanto instrumento de espacialização de políticas públicas de reforma agrária. Por ser recente objeto de estudo para arquitetos, o projeto de assentamento é tomado do ponto de vista das diretrizes de projeto e de sua resultante de implantação. Organizada a partir da aproximação com o contexto no qual foram criados, a pesquisa revela que foi entre a vigência dos dois planos nacionais de reforma agrária que foram criados o maior número de assentamentos em São Paulo, e que dos três tipos estudados, o assentamento federal foi o mais implantado. O estudo das diretrizes dos três tipos de projeto resultou na organização de indicadores e variáveis. Organizados em escalas de abordagem, revelam a história de criação do projeto e guiam a leitura do ambiente construído. Tomado como objeto de estudo, o assentamento Zumbi dos Palmares representa, com seus indicadores e variáveis, a maioria das ocorrências paulistas registradas na pesquisa.

Palavras-chave: arquitetura; assentamento rural; Iaras (SP); Zumbi dos Palmares

\begin{abstract}
The dissertation deals with the study of rural settlement project as a tool for spatialization of public policy for agrarian reform. For being recent object of study among architects, the settlement project is taken from the point of view of the project guidelines and their resulting deployment. Organized from the approach to the context in which they were created, the research reveals that between the two national plans for land reform that were created the largest number of settlements in São Paulo, and that of the three types studied, the federal settlement was the most deployed one. The study of the guidelines of three types of project resulted in the organization of indicators and variables. Organized on scales of analysis they reveal the history of the project creation and they also guide the reading of the built environment. Regarded as an object of study, the Zumbi dos Palmares settlement represents, with its indicators and variables, most part of the incidents in São Paulo that have been recorded through this research.
\end{abstract}

Keywords: architecture; rural settlement; Iaras (SP); Zumbi dos Palmares 


\section{Lista de figuras}

Figura 1: Assentamentos Rurais no Brasil 1985 - 1999

Figura 2: Assentamentos rurais em São Paulo - 1985 - 2012

Figura 3: Assentamentos rurais no Pontal do Paranapanema e em Andradina.

Figura 4: PDS Fazenda da Barra.

Figura 5: Projeto de Assentamento - PA Horto Aimorés: xadrez/espinha.

Figura 6: Projeto Estadual - PE Sumaré: agrovila

Figura 7: Projeto Estadual - PE Padre Josimo: roda de carroça

Figura 8: Fazendas adquiridas que constituíram o Núcleo Colonial Monções na região de Iaras.

Figura 9: Ocupação Norte e Sul do Núcleo Colonial Monções na região de Iaras.

Figura 10: Vista da cidade de Iaras.

Figura 11: Destaque da área ocupada com o parcelamento 1998

Figura 12: Destaque da área ocupada com o parcelamento 2003, 2005 e 2008

Figura 13: Destaque da área ocupada com o parcelamento 2012 e 2013

Figura 14: Síntese da evolução da ocupação

Figura 15: Projeto Estadual - PE Fazenda Guarani

Figura 16: Entorno regional de Iaras - escala macro 


\section{Lista de quadros}

Quadro 1: Tipo de assentamento rural implantado em São Paulo - 1985 - 2013

Quadro 2: Projetos de assentamentos rural

Quadro 3 : Cadernos que regulamentam a criação e implantação de PE

Quadro 4: Opção de parcelamento

Quadro 5: Forma de implantação dos assentamentos

Quadro 6: Variáveis do PE Sumaré

Quadro 7:Variáveis do PE Padre Josimo

Quadro 8: Passivo Ambiental Zumbi dos Palmares - 2000

\section{Lista de gráficos}

Gráfico 1: Assentamentos criados 1985 a 2011 em São Paulo. 


\section{Lista de tabelas}

Tabela 1: Assentamentos rurais criados no Brasil de 1985 a 2008

Tabela 2: Modalidades e valores do crédito instalação

Tabela 3: Tipos de projetos em SP

Tabela 4: Instruções técnicas do INCRA para a criação e a implantação de projeto de assentamentos rural em São Paulo

Tabela 5: Indicadores e variáveis para análise da criação e implantação do assentamento rural

Tabela 6: Iaras - população e município

Tabela 7: População rural Iaras

Tabela 8: Projeto de Assentamento Zumbi dos Palmares

\section{Lista de fotos}

Foto 1: Unidade habitacional assentamento Zumbi dos Palmares - Iaras/SP, 2013.

Foto 2: Casa construída com recursos do PMR

Foto 3: Perímetro urbano Iaras 138

Foto 4: Entrada do AZUP 139

Foto 5: Ônibus quebrado - Rod. Osni Mateus SP 261 140

Foto 6: Rod. Osni Mateus SP 261 140

Foto 7: Primeiro acampamento na Fazenda Capivara - Rodovia SP 261 e plantação de eucaliptos, 1995. 
Foto 8: Acampamento na Rodovia SP 261 e a plantação de eucaliptos, 1996.

Foto 9: Posto de saúde da família

Foto 10: Escola de Ensino Fundamental

Foto 11: Bar do Maurício 
LISTAS DE SIGLAS E ABREVIATURAS

\begin{tabular}{|l|l|}
\hline APP & Área de Preservação Permanente \\
\hline ARZUP & Associação Rural do Zumbi dos Palmares \\
\hline AZUP & Assentamento Zumbi dos Palmares \\
\hline CADMUT & Cadastro Nacional de Mutuários \\
\hline CC & Conselho Curador \\
\hline CC FGTS & Carta de Crédito com Operações Coletivas \\
\hline CDHU & Companhia de Desenvolvimento Habitacional Urbano \\
\hline CEF & Caixa Econômica Federal \\
\hline CESP & Companhia Energética de São Paulo \\
\hline COCAFI & $\begin{array}{l}\text { Cooperativa de Comercialização e Prestação de Serviços dos Assentados da } \\
\text { Reforma Agrária de Iaras e Região }\end{array}$ \\
\hline CONAB & Companhia Nacional de Abastecimento \\
\hline COOPDAI & Cooperativa de Produção Diversificada de Alimentos de Iaras \\
\hline EMBRAPA & Empresa Brasileira de Pesquisa Agropecuária \\
\hline FAO & Organização das Nações Unidas para Alimentação e Agricultura \\
\hline FDS & Crédito Solidário \\
\hline FEBEM & Fundação Estadual do Bem Estar do Menor \\
\hline FGTS & Fundo de Garantia por Tempo de Serviço \\
\hline FJP & Fundação João Pinheiro \\
\hline IBGE & Instituto Brasileiro de Geografia e Estatísticas \\
\hline IBS & Instituto Bio Sistêmico \\
\hline IDH & Índice de Desenvolvimento Humano \\
\hline IN & Instrução Normativa \\
\hline INCRA & Instituto Nacional de Colonização e Reforma Agrária \\
\hline IPRS & Índice Paulista de Responsabilidade Social \\
\hline ITESP & Fundação Instituto de Terras de São Paulo \\
\hline LA & Licenciamento ambiental \\
\hline LP & Licença Provisória \\
\hline
\end{tabular}




\begin{tabular}{|c|c|c|c|}
\hline MDA & Ministério de Desenvolvimento Agrário & & \\
\hline MST & Movimento Social dos Trabalhadores Rurais & & \\
\hline $\mathrm{NE}$ & Norma de Execução & & \\
\hline PAA & Programa de Aquisição de Alimentos & & \\
\hline PAA & Programa de Aquisição de Alimentos & & \\
\hline PDA & Plano de Desenvolvimento do Assentamento & & \\
\hline PMCMV & Programa Minha Casa Minha Vida & & \\
\hline PMR & Programa de Moradia Rural & & \\
\hline PNAE & Programa Nacional de Alimentação Escolar & & \\
\hline PNATER & $\begin{array}{l}\text { Plano Nacional de Assistência Técnica e Extensão Rural para agricultura } \\
\text { familiar e reforma agrária }\end{array}$ & & \\
\hline PRONHR & Programa Nacional de Habitação Rural & & \\
\hline PRONAF & Programa Nacional de Agricultura Familiar & & \\
\hline PRONATER & $\begin{array}{l}\text { Programa Nacional de Assistência Técnica e Extensão Rural para agricultura } \\
\text { familiar }\end{array}$ & & \\
\hline RB & Relação de Beneficiários & & \\
\hline RL & Reserva Legal & & \\
\hline RMC & Região Metropolitana de Campinas & $\mathrm{TA}$ & Tutela Antecipada \\
\hline SEADE & Fundação Sistema Estadual de Análise de Dados & $\mathrm{TC}$ & Tutela Complementar \\
\hline SIPRA & Sistema de Informações de Projetos de Reforma Agrária & UA & Unidade Avançada \\
\hline SR & Superintendência Regional & UNESP & Universidade Estadual Paulista \\
\hline $\mathrm{TA}$ & Tutela Antecipada & UNIARA & Centro Universitário de Araraquara \\
\hline
\end{tabular}




\section{Sumário}

AGRADECIMENTOS

INTRODUÇÃO

Capítulo 1 - Contexto e marcos

1.1 Contexto

1.2 Marcos institucionais - I e II PNRA

1.3 Projeto de Assentamento Rural

1.4 Habitação Rural

Capítulo 2 - Ocorrências em SP

2.1 Ações federais e estaduais

2.1.1 Projetos de Assentamento Federal - PA

2.1.2 Projeto de Desenvolvimento Sustentável - PDS

2.2 Arquitetura dos assentamentos: implantação e parcelamento

2.2.1 Xadrez - espinha de peixe 
Referências Bibliográficas 


\section{INTRODUÇÃO}

Tendo partido das questões suscitadas durante a experiência profissional como arquiteta - acompanhando a construção de unidades habitacionais nos assentamentos rurais em São Paulo - a pesquisa teve como objetivo estudar os projetos e as resultantes de implantação dos assentamentos rurais em São Paulo. A precariedade do ambiente construído, as dificuldades em operar o programa de moradia rural, somadas ao pouco conhecimento do cenário no qual foram instituídos no Brasil, foram fatores que motivaram a pesquisa.

Em São Paulo, apesar de recentes, alguns grupos de pesquisa têm tratado das questões do habitat nos assentamentos rurais, mas com ênfase no estudo das unidades habitacionais: seu programa, suas formas de provisão e suas técnicas construtivas. Mais desenvolvidas nas linhas da economia, geográfica e das ciências sociais, são raras as pesquisas que se dedicam ao estudo das condicionantes deste projeto no âmbito da arquitetura. Embutidas nas normas e diretrizes, orientam o parcelamento do solo e determinam as condições do ambiente que ali irá se constituir. Toma-se como cenário para a pesquisa os marcos que instituem e regulamentam a criação dos projetos de assentamentos rurais no Brasil - I e II Plano Nacional de Reforma Agrária -, suas políticas e programas que, decorrentes desse contexto, se materializam a cada implantação.

Os primeiros assentamentos, implantados na região do Pontal do Paranapanema 
em terras estaduais ${ }^{1}$, fizeram a região ficar conhecida pelos conflitos fundiários que deram origem às primeiras implantações paulistas. Com o passar do tempo, mesmo tendo ficado por anos à margem das políticas públicas, há um aprimoramento nos instrumentos de materialização do assentamentoe as implantações passam a ocupar outras regiões, especializando-se no interior do Estado.

Implantados nos pequenos municípios do interior de São Paulo, os assentamentos rurais do programa de reforma agrária são resultado de ações esparsas que não fazem parte de um planejamento estratégico territorial articulado, no qual as esferas federal, estadual e municipal funcionam com a participação social. O que se verifica, na maioria dos casos, é o reflexo de reivindicações sociais que dão origem às ações institucionais de desapropriação/ aquisição de terras.

\section{Problemática}

A criação de um assentamento, ainda que siga as diretrizes que determinam sua metodologia de projeto, em cada implantação, tem um resultado de parcelamento que pode ser diferenciado pela forma de organização dos lotes e do traçado das vias. Identificados e reconhecidos na pesquisa, alguns aspectos puderam ser destacados na definição de variáveis e indicadores que contribuem para o estudo dos projetos de assentamento. A variação do tamanho dos lotes está relacionada ao módulo rural² de cada município, ao tamanho da família. Em São Paulo, se o beneficiário é idoso ou se a família é pequena - até duas pessoas
1 São terras públicas, que em nenhum momento integraram o patrimônio particular, ainda que possam estar

irregularmente em posse de particulares. $\mathrm{O}$ termo "devoluta" relaciona-se ao conceito de terra devolvida ou a ser

devolvida ao Estado. Para estabelecer o real domínio da terra, ou seja, se é particular ou devoluta, o Estado

propõe ações judiciais chamadas 'ações discriminatórias', processo elaborado pelo Instituto de Colonização e Reforma Agrária - INCRA (ITESP, 2014).

${ }^{2}$ Unidade de medida expressa em hectares. Definido pelo Estatuto da Terra é utilizado para determinar a fração mínima de parcelamento de um imóvel rural. 
- é disponibilizado o lote pararrural, com dimensão reduzida.

A maioria dos projetos de assentamentos criados em São Paulo teve a definição do uso do solo resultantes do planejamento feito sob aspectos produtivos. A dimensão econômica sempre prevaleceu no momento de parcelamento dos lotes nos assentamentos. Para MARQUES (2000), a transição do acampamento para o assentamento é reconhecida como um ritual de passagem no qual uma nova relação é constituída com a terra e, consequentemente, com esse novo lugar que se constrói com a implantação de cada assentamento.

Em São Paulo foram identificadas regiões que se qualificaram pela presença de assentamentos. Desde 2010, ações de descentralização foram tomadas para cumprimento da Lei de Assistência Técnica que obriga o Estado a disponibilizar técnicos especializados para atender os beneficiários da reforma agrária. Nesse sentido, foram criados escritórios satélites e unidades avançadas para atender as diferentes regiões do estado.

Como dito, o interesse pelas questões sobre os projetos de assentamento é decorrêcia de questões que surgiram em minha prática profissional como arquiteta, desempenhando atividades de assistente de desenvolvimento agrário no Instituto de Colonização e Reforma Agrária em São Paulo (INCRA/SR08). Nessa função, acompanhei a construção de cerca de mil unidades habitacionais em mais de 150 assentamentos rurais espalhados pelo interior do estado. $O$ trabalho consistia em vistorias técnicas para medir os serviços 
executados e apresentar a evolução do cronograma físico financeiro de cada unidade habitacional contratada. Organizada em uma modalidade de operação coletiva bem sucedida nas cidades, a construção das casas dependia do sistema de mutirão ou da autoconstrução assistida. O programa foi promovido nos assentamentos paulistas como programa piloto de provisão de moradia. Atuando principalmente no centro-oeste do estado, a dinâmica do trabalho compreendia atividades no escritório do INCRA, em São Paulo, nos escritórios regionais e idas aos assentamentos para vistoriar cada casa, sendo necessário percorrer quilômetros em estradas de terra.

A carência de infraestrutura, a precariedade das estradas, a ausência de escolas, usos comerciais, prestação de serviços, despertaram questões sobre como se dá a elaboração do projeto, isto é, sobre qual o programa de necessidades definido para criação dos projetos de assentamento.

Ao longo do tempo em que acompanhei as obras no assentamento Zumbi dos Palmares observei incongruências e cisões entre o que estava previsto no roteiro de operacionalização que orientava a construção das casas, e aquilo que era possível fazer na prática, sinalizando que a etapa de criação - seja do programa para construção das casas, seja para o projeto do assentamento - ainda tem sido desenhada distante das condições reais de operação. Tais incongruências despertaram as primeiras questões trazidas para reflexão e registro neste trabalho. 
Previstas para serem realizadas em mutirão, as casas estavam sendo construídas quase que individualmente, e a falta de articulação entre as famílias, os diferentes interesses e as dificuldades na dinâmica de compra e entrega de material no assentamento foram os gargalos na execução do programa. As distâncias a serem percorridas entre lotes implicaram tempo para fazer as vistorias, o que não foi considerado na definição do prazo de liberação de recursos, assim como não foi considerada a localização dos lotes no momento de organiz ção dos grupos de construção.

A inoperância do programa de moradia rural em São Paulo apontou uma problemát ca que sinalizava não só a falta de capacidade operacional das entidades envolvidas na operação do programa, como também o formato previsto para execução das obras: ao contrário do imaginado, o mutirão e o prazo estabelecido demonstraram ser inviáveis na realidade dos assentamentos paulistas.

Ao final de 2008, a situação construtiva das unidades habitacionais era variada. Se, por um lado, no extremo oeste do estado estavam algumas experiências mais bem sucedidas e organizadas, como por exemplo nos assentamentos do Pontal e de Andradina, por outro, haviam regiões consideradas como pontos críticos. Eram as regiões de Iaras e Itupeva. Na primeira, o assentamento Zumbi dos Palmares; na segunda, o Pirituba. Ambos apresent vam problemas e gargalos que ultrapassavam a esfera técnica e a construtiva, pois envolviam também aspectos físicos - como o tamanho da área ocupada pelo assentamento - e sociais que 
precisavam de maior dedicação - como a organização das famílias.

Organizado em agrovilas, o assentamento Pirituba enfrentava problemas como a demanda por construir duas unidades habitacionais, ou reformar uma e construir outra. Nesse tipo de assentamento, em agrovila, o beneficiário têm dois lotes: um no qual vive com a família, e outro no qual organiza sua produção. No assentamento Zumbi dos Palmares o problema eram as obras paralisadas por falta de organização dos grupos que, por conta da extensão da fazenda e do modo de agrupamento, dificultava a articulação das famílias.

A complexidade da problemática gerada com a construção das casas remetia não só à dificuldade de promover o mutirão, mas também indicava que a forma como as famílias foram agrupadas não considerava a proximidade dos lotes. O agrupamento das famílias foi realizado de acordo com a ordem de chegada do documento, sem considerar a proximidade entre eles ou mesmo a relação social entre as famílias.

No Zumbi dos Palmares, as dificuldades verificadas eram comuns àquelas ocorridas em outros assentamentos: o atraso das obras, as dificuldades na entrega do material e a qualidade do material entregue. As especificidades na constituição deste projeto de assentamento são tomadas como referência para este estudo, pois ilustram a criação e a transição entre projeto e implantação de um assentamento rural paulista. Neste caso, sua transição durou quinze anos, implicando não só as alterações do projeto inicial - seja na capacidade de lotes ou no tipo de uso do solo definido -, como também no contexto nacional gerando 
alterações significativas no ambiente construído nos assentamentos rurais.

Organizado para contextualizar a origem da criação dos assentamentos rurais, o primeiro capítulo apresenta na primeira parte o contexto no qual foram criados. $\mathrm{Na}$ segunda parte são apresentados os marcos que instituíram os projetos de assentamento: o I e o II Planos Nacionais de Reforma Agrária, organizadores das políticas e dos programas que criam os projetos de assentamento. Na terceira parte, apresenta-se um estudo sobre as definições e diretrizes que criam o projeto, seja ele definido nas esferas públicas ou pelo movimento social. Na quarta parte do capítulo apresentam-se as políticas e os programas específicos, dando ênfase à questão da habitação rural.

Dividido em duas partes, o segundo capítulo apresenta, na primeira, o resultado das ações federais e estaduais especializadas em São Paulo. Apoiada no levantamento realizado, apresentam-se três tipos de projeto para assentamentos paulistas: assentamento federal, estadual e o de desenvolvimento sustentável. Na segunda parte, o projeto é tratado do ponto de vista da arquitetura. Num estudo das resultantes de implantação são reconhecidos os tipos de parcelamento que se reproduzem no Estado: xadrez, agrovila e roda de carroça.

O terceiro capítulo apresenta a justificativa para definição do assentamento Zumbi dos Palmares como objeto de estudo desta pesquisa. Na segunda parte desse capítulo são apresentadas as escalas de abordagem e os critérios adotados para estudar primeiramente a 
criação, conforme processo arquivado no INCRA (SR08). Para consolidar a elaboração de uma matriz, tomou-se como referência uma parte da estrutura das notas metodológicas organizadas pela pesquisa INCRA/UNIARA (FERRANTE, 2012).

O quarto capítulo apresenta o estudo realizado no assentamento Zumbi dos Palmares a partir do levantamento de campo, organizado conforme descrito no capítulo anterior. Esse capítulo dá certa ênfase ao relato de algumas pessoas com quem foi possível conversar durante a visita, são moradores ou líderes que representam as famílias. As escalas de abordagem que registraram aspectos e condicionantes do assentamento - aqui apresentadas por ilustrações, fotos, e relato dos técnicos assim como de alguns moradores do assentamento - guiaram a compreensão do ambiente construído. Por fim, nas considerações, a reflexão elaborada busca organizar uma perspectiva acerca das possibilidades que se colocam, do ponto de contato entre as diretrizes de projeto para os assentamentos rurais e sua materialização, sobretudo na prática em campo. Estariam os assentamentos rurais, por sua precariedade instalada, tornando-se um tipo de favela do meio rural? 


\section{Capítulo 1}

\section{Contexto e marcos}

\subsection{Contexto}

A condição agrária no País tem suas origens no processo de ocupação do território no período colonial. Este padrão de parcelamento deu origem ao latifúndio, modelo de propriedade rural predominante na ocupação do espaço agrário brasileiro. Desde então, como afirma Maricato (2008), seja no campo ou na cidade, a propriedade da terra continua a ser o nó dos conflitos da sociedade brasileira.

A inauguração do conflito em torno da questão fundiária remete à instituição da Lei de Terras de 1850 (MARICATO, 1999), que impediu formalmente que os trabalhadores rurais se estabelecessem na terra pela posse. Nesse período, originam-se também a tradição da monocultura e a produção em grande escala para abastecimento do mercado externo. $\mathrm{Na}$ história do Brasil, esse formato produtivo se reafirma nos ciclos econômicos seguintes, com a pecuária e com a cultura do café.

Considerando-se que, na história do Brasil, o Estado foi comandado pelos interesses da elite rural, as políticas públicas voltadas à produção agrícola foram direcionadas ao fortalecimento da monocultura extensiva - produtora de matérias primas - para subsidiar as multinacionais ou transnacionais do agronegócio ${ }^{3}$, responsáveis pela transformação da paisagem natural do interior paulista.

${ }^{3}$ Agronegócio é o conjunto de negócios relacionados à agricultura do ponto de vista econômico. É dividido em três partes: a) A de negócios agropecuários propriamente ditos (ou de "dentro da porteira") que representam os produtores rurais, sejam eles pequenos, médios ou grandes produtores, b) os negócios à montante (ou "da pré-porteira") aos da agropecuária, representados pela indústria e pelo comércio que fornecem insumos para os negócios agropecuários. c) negócios à jusante (ou "pós-porteira") que são aqueles negócios que compram os produtos agropecuários, os beneficiam, os transportam e os vendem para os consumidores finais (NEAD, 2010) 
Esse processo pode ser descrito como uma monotonia extensiva. Teve início em São Paulo, no governo Carvalho Pinto (1959/1963), com a “Lei de Revisão Agrária, com a qual foi possível o assentamento de camponeses sem terra em áreas públicas ou em áreas privadas subutilizadas mediante compra pelo governo do Estado" (BOMBARDI apud ARRUDA, 2005, p. 35)

Entretanto, o início do período militar brecou o processo da reforma agrária recéminiciada. A política de desenvolvimento agropecuário adotada foi caracterizada por uma ocupação do território incentivada pela abertura de rodovias que avançaram pelo interior, formalizando a estratégia de expansão das frentes agrícolas, com objetivo de abastecer o mercado internacional. Nesse momento, o cenário do meio rural assistiu, de um lado, a intensificação do seu esvaziamento, reafirmado com a migração da população para a cidade; e, de outro, o fortalecimento das organizações sociais que, ao final do período, se consolidaram a exemplo da experiência do Movimento dos Trabalhadores Rurais Sem Terra - MST, que se tornou o agente fundamental de demanda por assentamentos em todo o país desde 1984.

As características do meio rural contemporâneo são decorrentes do processo de colonização e das transformações que redesenharam o território brasileiro a partir dos anos 30 do século XX. As prioridades assumidas pela política econômica, entre os anos 50 e 70, fizeram o Brasil assumir o caráter de um país urbano, marcado por um êxodo rural importante para cidades que não estavam preparadas para receber tamanho contingente populacional. Resultante desse processo são as favelas, que se espalharam em diversas áreas, dando forma aos assentamentos precários urbanos que definiram a pauta das pesquisas, estudos e políticas públicas dos anos seguintes. 
O processo de transformação desse quadro foi marcado pela adoção, por parte do governo, de diretrizes de desenvolvimento do país que previam investimento e planejamento apoiados em dois modelos de expansão, um para o campo e outro para a cidade. A expansão industrial prevista para as cidades se sobrepôs de forma violenta ao cotidiano dos agricultores familiares - presentes em todo o processo histórico - com o modelo produtivista projetado para o campo. Ao longo desse processo, é possível observar a ausência de investimentos e de políticas públicas direcionadas à população rural que não só trabalhava, mas vivia no campo e foi atraída para as cidades, que não estavam preparadas para receber esse enorme contingente (ZUQUIM, 2008).

Dessa maneira, o desenho do meio rural se desenvolveu com a ocupação de extensas faixas do território, provocando conflitos fundiários e promovendo a concentração de terras e riquezas. O fortalecimento da produção extensiva e de exportação moldou o espaço rural a partir dessas grandes propriedades, fortalecendo o movimento do êxodo rural em direção aos centros urbanos industrializados.

Nos anos 1960 e 1970 as consequências desse modelo já eram visíveis do ponto de vista social e ambiental, o que gerou, ao longo dos anos, uma tomada de consciência sobre outras possibilidades para o desenvolvimento econômico e social. Nesse período aparecem os primeiros movimentos sociais organizados que demonstram publicamente a preocupação com os problemas gerados pelas diferenças sociais e com forma adotada para o uso do território. Esse é o início da participação popular no que foi denominado "reformas de base" - agrária e urbana. (ZUQUIM, 2008).

A política desenvolvimentista proposta pelos governos militares foi seguida pelo "milagre econômico". Além da repressão dos incipientes movimentos sociais, as transfor- 
mações econômicas determinaram prioridades das políticas públicas para as questões de desenvolvimento urbano. Foi dessa maneira que o Brasil passou a ser definido, de dentro para fora, como país urbanizado, privilegiando as políticas e os investimentos da economia urbana e industrial. Nesse período, a adoção de novas tecnologias para as atividades do meio rural favoreceu a exclusão das pequenas e médias propriedades, proporcionando mais espaço para a grande propriedade, caracterizada não só pela modernização, mas também pela mecanização atrelada à adubação química, resultando, assim, em uma estrutura fundiária concentrada. (ZUQUIM, 2008).

O processo de modernização da agricultura proposto no $1^{\circ}$ Plano Nacional de Desenvolvimento (PND), proposto pelo regime militar, tinha como meta uma agricultura de base empresarial que alcançasse condições de competitividade internacional nos principais produtos, a partir de créditos subsidiados que favoreciam os proprietários de grandes propriedades e deixavam de lado a agricultura familiar, um modelo de produção que pode ser observado nos assentamentos rurais.

Entre os anos 1980 e 1990, a agricultura familiar não apresentava condições de competir com os produtores extensivos à concorrência internacional, ficando submetida aos efeitos do modelo econômico, reproduzido desde o sistema colonial, no qual a base é a produção dos produtos primários para exportação.

A problemática que se inscreve com a essa situação, além da concentração de terras e da expulsão dos agricultores do campo, implica a manutenção da fome e da pobreza, características do país desde o processo de colonização. É a manutenção do status quo - a reprodução do processo que mantém as bases do país inalteradas, dificultando o processo de desenvolvimento interno. 
A partir dos anos 90, podemos observar uma mudança na posição das novas políticas mundiais que promovem o afastamento gradual do poder público que antes era regulador entre o interesse público e a sociedade, passando a assumir uma função de intermediador dessas relações (ZUQUIM, 2008).

Esse período traz novas características para a zona rural. A interface entre o espaço urbano e o espaço rural não é clara, pois o uso do espaço rural já não é mais essencialmente agrário. As áreas rurais passam a incluir atividades de lazer, turismo, residência, preservação ambiental, entre outras, como, por exemplo, os assentamentos rurais que associam em sua implantação características urbanas e rurais não muito definidas.

Os assentamentos rurais representam o esforço, por parte do poder público, em responder não só a demanda por terra, mas também de enfrentar a problemática da falta de acesso à terra resultante do processo de ordenamento do território nacional. Esses assentamentos são objeto de políticas públicas nacionais e estaduais para o desenvolvimento agrário, e foram implantados a partir da redemocratização do país. Esse modelo de reforma agrária, descrito como praticamente residual, esteve apoiado em alianças cruzadas entre partidos políticos e setores ligados às oligarquias agrárias, visando à manutenção de uma estrutura fundiária arcaica (MARTINS apud ARRUDA, 2007, p. 30).

Considerando que depois da implantação, o assentamento está em constante transformação, este tipo de loteamento faz parte da configuração do território nacional há quase 30 anos. O problema é que a insuficiência de políticas públicas, de créditos e a precária infraestrutura disponibilizada implicaram em condições pouco favoráveis ao desenvolvimento duradouro das famílias. Ainda assim, é possível observar que nos últimos dez anos houve um incremento na oferta de políticas diferenciadas para as necessidades específicas 
dos assentamentos rurais, seja no âmbito federal como no estadual. Contudo, ainda não são observados casos de assentamentos que tenham se consolidado suficientemente de modo a atingirem a emancipação em relação às políticas públicas.

O Estado distribui terras, mas não investe capital necessário para um planejamento de longo prazo. Não são criadas condições institucionais e financeiras suficientes para prover a estruturação dos assentamentos e de seus sistemas produtivos. Ao contrário, o que se verifica é um relativo abandono dos assentados pelo INCRA e entidades mediadoras após a entrada no lote, além de um trabalho de assistência técnica limitado. Dessa maneira, verifica-se a inexistência de casos de emancipação de assentamentos, mesmo depois de mais de uma década de Reforma Agrária (MARQUES, 2000).

O assentamento é uma forma de parcelamento organizado na zona rural. A maioria deles são constituídos numa área extensa, no lugar de uma grande propriedade improdutiva, ou latifúndio, e estão regulamentados pelo Estatuto da Terra (BRASIL, 1964), que também assegura a oportunidade de acesso à propriedade da terra, condicionada ao cumprimento de sua função social:

$\S 1^{\circ}$ A propriedade da terra desempenha integralmente a sua função social quando, simultaneamente:

a) favorece o bem-estar dos proprietários e dos trabalhadores que nela labutam, assim como de suas famílias;

b) mantém níveis satisfatórios de produtividade;

c) assegura a conservação dos recursos naturais;

d) observa as disposições legais que regulam as justas relações de trabalho entre os que a possuem e a cultivem. (BRASIL, 1964).

No Brasil, esse tipo de propriedade sempre esteve associado, e permanece ainda hoje, a inúmeros conflitos sociais. A problemática fundiária no país, durante a ditadura até 
a transição para o neoliberalismo, foi mantida de acordo com o interesse dos latifundiários, proprietários das grandes fazendas que, por um longo período de tempo representaram a classe dominante do campo. Os conflitos gerados deram origem às ocupações de terras que reivindicam o destino dessas propriedades. Os assentamentos rurais são um modelo adotado como resposta do governo a uma demanda social por distribuição de terras, que se expressa nas ocupações e reivindicações dos movimentos sociais organizados.

Quando uma área, depois de vistoriada, é destinada à implantação de um assentamento rural é porque sua situação está em desacordo com o cumprimento da função social descrita na legislação. Os assentamentos também podem ser ordenados em áreas onde se localizavam, por exemplo, hortos florestais que produziam madeira para atender a manutenção das linhas férreas paulistas, hoje extintas pelo modelo de desenvolvimento apoiado no rodoviarismo; ou áreas de outras empresas públicas, que se extinguiram nesse mesmo processo histórico.

O assentamento constitui um ambiente diferente a cada implantação; é um lugar não só de trabalho, mas também de moradia para as famílias beneficiadas, por isso, o resultado construído parece ser importante objeto de pesquisa. Os estudos realizados sobre os assentamentos rurais tratam esse objeto do ponto de vista produtivo, ambiental e social. São raros os que se dedicam à compreensão do assentamento enquanto habitat ${ }^{2}$ das famílias assentadas, isto é, enquanto lugar de moradia.

O acampamento - fase anterior ao assentamento - caracteriza a forma de ocupação na fase de luta pela terra. Nesse momento, as famílias estão organizadas em barracos de lona, colados uns aos outros. Com formas diferentes de organização, dependendo da área disponível, é implantado linearmente nas margens de rodovias, ou em pequenas vilas orga-
4 O habitat é entendido na pesquisa como o lugar que se constrói a partir das atividades do cotidiano e do conjunto de relações sociais e o assenta sto como lugar de moradia, na tentativa de detectar os elementos e aspectos que podem contribuir na indicação da cultura habitacional dos assentamentos rurais. 
nizadas, com divisão de tarefas definidas e coordenadas. Para estudar o projeto e a implantação de um assentamento rural faz-se necessário compreender que este é resultado de um longo e intenso processo: pode ser interpretado como um rito de passagem (MARQUES, 2000). A fase de luta pela terra é espacializada, na forma do acampamento; é um momento em que a organização do grupo é indispensável para a sobrevivência, sendo assumida como estratégia de luta. Normalmente, o tempo no acampamento é longo, e as condições, que têm de ser superadas, são precárias. Essa superação é alcançada a partir da organização do grupo, que se divide na execução das tarefas incluídas na vida no acampamento: desde a provisão de alimentos, a limpeza, o cuidado com as crianças, até a participação em reuniões políticas e atividades do movimento. Nessa fase, são raras as oportunidades em que as famílias conseguem organizar uma horta para os alimentos do dia a dia das famílias, nesta etapa, dependem principalmente de doações, da igreja, ou de outros assentados da região.

Os assentamentos podem ser considerados comunidades rurais específicas, não só por sua origem, ou pelo caminho de luta das famílias, mas porque habitar esse lugar é um marco que finda o processo de transição entre o acampamento o início de um cotidiano marcado pela espacialização de políticas públicas adotadas pelas esferas governamentais. Porém, nem sempre são construídos de forma integrada e contínua, o que pode ser verificado na constituição desses assentamentos.

É grande o potencial dessas áreas para o desenvolvimento socioeconômico, pois concentrar assentamentos rurais em uma mesma microrregião permite ao poder público um enfoque no desenvolvimento territorial sustentável. A recuperação desse patrimônio público traz a perspectiva de construir uma grande área reformada, por exemplo, no centro do Estado de São Paulo, que facilitará a integração produtiva dos trabalhadores assentados e a sua articulação com os mercados locais. (INCRA, 2011). 
Para Bergamasco (1996), as demandas por assentamentos refletem a implementação de novas formas de núcleos rurais. Os assentamentos e vilas que alteram a relação campocidade causam efeitos locais e regionais. Para essa autora, é quase contraditório que os espaços rurais contribuam como elemento da problemática e não como fator de equilíbrio e gestão de ordenamento territorial. É por tudo isso que se justifica a proposta de se olhar o projeto de assentamento como forma de ocupação humana específica, e de se compreender a constituição do habitat desses assentamentos que compõem o mosaico do meio rural paulista.

Os procedimentos técnico-burocráticos para a implantação do assentamento, nem sempre, ou quase nunca, consideram as dinâmicas do cotidiano. Nesse caso, entende-se que o cotidiano da família assentada é permeado constantemente por ações e por agentes externos que trabalham no sentido de viabilizar a fixação das famílias no lote, operacionalizando programas e ações das políticas de governo.

\subsection{Marcos institucionais - I e II PNRA}

A demanda por terra organizada teve conquistas relevantes com a instituição dos Planos Nacionais, de 1985 e de 2003 (BRASIL, 1985/2003), que mantiveram a questão agrária nas pautas dos governos, com a criação de políticas e programas, na tentativa de fixação das famílias nos lotes dos assentamentos criados. Embora não tenham sido cumpridas as metas propostas, entende-se que a constituição de um projeto de assentamento implica formas de organização de núcleos rurais, assim como os Núcleos de Colonização implantados 
no período anterior direcionados ao assentamento de colonos estrangeiros.

Na história do Brasil, foi apenas com os planos de governo de 1985 e de 2003 que foram estabelecidas metas e diretrizes para implementar o Programa de Reforma Agrária, definido em 1964, com base nos dispositivos do Estatuto da Terra que responsabiliza o poder público pelo acesso à propriedade ao trabalhador rural. Mesmo que o Estatuto da Terra $^{5}$ tenha sido promulgado em 1964, os primeiros assentamentos rurais do programa de reforma agrária ${ }^{6}$ só foram implantados a partir de 1983, com os primeiros processos de desapropriação de terras. Mas, foi somente em 1985, com o I Plano Nacional de Reforma Agrária - I PNRA - que foi apresentado como plano de governo.

Para entender esse processo, é preciso ter claro que o Estado não é seu único e nem seu principal agente. Ao contrário, o que se verifica é a forte ação da sociedade civil organizada em movimentos sociais que lutam pelo direito à terra, reivindicam o acesso e pressionam o Estado, que responde por meio da constituição de um assentamento rural. Com ações esparsas, que não fazem parte de um planejamento estratégico territorial, não se verifica um processo de reforma agrária, mas sim com uma luta organizada que, a partir das reivindicações, produz ações institucionais de desapropriação que resultam nos assentamentos.

Organizada para ser implantada no período de 1985 a 1989, a meta do I PNRA era beneficiar um milhão e quatrocentas mil famílias. Estava incluída nesse montante a demanda por terra manifestada desde os anos 1960, época em que os habitantes do campo se organizaram para reivindicar o direito à sindicalização - movimentação logo reprimida pelo regime militar. Elaborado para ser executado pelo Instituto de Colonização e Reforma Agrária (INCRA), o Plano indicava a execução de programas complementares, como a regularização fundiária ${ }^{7}$, a colonização e a tributação da terra. Na definição dos princípios
5 Lei 4504, 30 de novembro de 1964. Regulamenta os direitos e as obrigações relativas aos imóveis rurais para os fins da reforma agrária, e responsabiliza o poder público pelo acesso à propriedade da terra para o trabalhador rural.

6 Lei No 8.629, de 25 de fevereiro de 1993. Regulamenta e disciplina as disposições relativas à reforma agrária, prevista na política agrícola, fundiária e da reforma agrária no capítulo III da constituição da república federativa do Brasil de 1988. 
básicos para a reforma pretendida o Estatuto da Terra constou como instrumento direcional:

Considera-se reforma agrária o conjunto de medidas que visem a promover melhor distribuição da terra mediante modificação no regime de sua posse e uso, a fim de atender aos princípios de justiça social e do aumento da produtividade (BRASIL - ESTATUTO DA TERRA, 1964).

A proposta de reforma é concebida no Plano como estratégia de ação governamental. Isso significa que, para sua implementação, seria necessária a ação integrada entre as esferas federal, estadual e municipal, além da participação social. Por isso, a necessidade de uma Política Agrícola é incluída no texto como parte de um conjunto de providências na tentativa de solucionar os problemas fundiários, incluindo ainda a questão ambiental, seja ela relacionada à conservação dos recursos naturais ou de caráter preventivo e educativo. Assim, é necessário que cada projeto tenha especificado um zoneamento ambiental, associando a ordenação do espaço físico e respeitando a vocação de cada área.

Ao tratar da seleção de beneficiários, o texto do I PNRA considera como problemática a falta de organização das famílias nas experiências anteriores de assentamentos rurais e, por isso, sugere encaminhamento da questão em duas direções. A primeira, diz respeito aos sistemas de posse e uso da terra; a segunda, relaciona-se com a imobilização e a organização socioeconômica dos beneficiários, com vistas à promoção e/ou organização de um sistema de produção e comercialização de acordo com os interesses e a vontade dos assentados (BRASIL, 1985).

Entre os anos 1980 e 1990, a agricultura familiar não apresentava condições de competir com os grandes produtores na concorrência internacional, ficando submetida aos efeitos do modelo econômico reproduzido desde o sistema colonial, no qual a base foi a produção de produtos primários para exportação. Percebe-se aí o contraponto da situação, quando se leva o foco para o cenário do mercado interno. Os dados do IBGE 2006 apontam que a pro-
Regularização fundiária é um programa do Governo do Estado de São Paulo que tem como objetivo eliminar a indefinição dominial, ou seja, estabelecer com precisão de quem é a posse da terra para depois legitimá-la ou regularizá-la, garantindo segurança social e jurídica para pequenos agricultores e moradores de áreas urbanas, e auxiliar os municípios no dimensionamento da arrecadação de impostos e elaboração de planos diretores (ITESP, 2014). 
dução agrícola brasileira representa cerca de $70 \%$ da produção de alimentos no país; sendo a base econômica da maioria dos municípios, responde por 35\% do PIB nacional, e por $40 \%$ da população economicamente ativa (BRASIL, 2009).

Esse período revela novas características da zona rural. A interface entre a cidade e o campo não é clara, e o uso do espaço rural já não é mais essencialmente agrário. Essas áreas passam a incluir atividades de lazer, turismo, residência, preservação ambiental. São exemplos de tais mudanças os assentamentos, que associam em sua implantação características urbanas e rurais, as quais representam o esforço, por parte do poder público, em responder à demanda por terra resultante do processo de ordenamento do território nacional.

Considerando que a implantação de um assentamento está em constante transformação, a expectativa era que depois de 20 anos as famílias se emancipassem, ou seja, pudessem se tornar independentes das políticas públicas. Entretanto a falta de articulação entre o desenho dessas políticas e a precária infraestrutura disponibilizada implicaram, contrariamente, condições pouco favoráveis ao desenvolvimento das atividades econômicas das famílias. Embora se observe que nos últimos anos tenham existido incrementos na oferta de políticas diferenciadas para atender necessidades específicas dos assentamentos - seja no âmbito federal, seja no estadual -, a maioria deles ainda não foi emancipada.

Se por um lado o texto do decreto que aprova o I PNRA parece detalhado e abrangente, por outro, ao se analisarem os processos e critérios de desapropriação, pode-se perceber que as pressões políticas do grupo de representantes dos latifundiários diluíram o efeito de reforma proposto.

As ações de governo são produto dos compromissos assumidos nos processos eleitorais, ou de negociações com a sociedade organizada. Sua execução e o seu ritmo de imple- 
mentação podem ser condicionados pela capacidade de mobilização e reivindicação da sociedade civil e de setores econômicos, ou de negociação com a base de sustentação política. Dessa maneira, muitas vezes, no desenrolar de um governo programas e ações são criados, paralisados, ou secundarizados (JUNIOR; FERRANTE, 2012).

Diante do insucesso ocasionado pelo "esquecimento" do Plano, o debate em torno da constituinte, realizado nos anos 1987/1988, contou com a presença do recém criado MST que apresentou a ementa popular sobre reforma agrária.

[...] a partir dos anos 90 o MST constituirá um de seus núcleos mais dinâmicos exatamente na região do Pontal do Paranapanema em São Paulo. A reconhecida irregularidade fundiária e o contexto geral de concentração das terras alavancou a territorialização desta organização. (FERRANTE; BARONE, et al, 2012, p.52)

O resultado desse debate tomou forma na publicação da Constituição Federal de 1988 (BRASIL, 1988), na qual se estabelecem quatro dispositivos para o cumprimento da função social da propriedade rural, sendo que a manutenção de níveis satisfatórios de produtividade é tomada como seu principal indicador. Dessa maneira, a articulação dos grandes latifundiários manteve o modelo agropecuário concentrador que vigora até hoje. Além disso, o fato de tornar "produtiva" a grande propriedade, independentemente de seu tamanho, faz com que fique insusceptível à desapropriação para fins de reforma agrária.

A tomada desse indicador como norteador da política de distribuição de terras implicou a redução de sua abrangência, havendo, consequentemente, certo retrocesso em relação ao Estatuto da Terra. Outros requisitos, porém, são difundidos para execução do processo de desapropriação, entre eles, a conservação dos recursos naturais, o cumprimento das leis que regulam as relações de trabalho entre proprietários e trabalhadores e o bem-estar dos envolvidos. 
Em 1993, os dispositivos da Constituição relativos à reforma agrária foram regulamentados, e a definição de "propriedade produtiva" restringiu-se então aos aspectos econômicos, não considerando os sociais e ambientais. Somaram-se a essa condição, intervenções pontuais de assentamentos isolados, sem a declaração, por parte do Estado, de áreas ou regiões prioritárias para fins de reforma agrária. Nesse cenário, não foi possível uma intervenção ampla prevista no I PNRA, como parte de um planejamento regional que priorizasse regiões com investimentos em infraestrutura e melhor distribuição de renda (HEINEN, 2005).

Percebe-se que o aparato regulatório, as leis e decretos que vão desenhar a extensão rural do país, ano a ano, governo após governo, giram em torno de si mesmos. Ao que parece, ainda estão distantes daquilo que se pratica em campo no transcorrer da implementação de cada projeto de assentamento. Por exemplo: apesar de o governo Collor, seguido do de Itamar Franco, juntos, terem realizado algumas desapropriações, não atualizaram o I PNRA e tampouco redefiniram suas metas. Tratou-se mais de ações esparsas e de caráter emergencial - com o objetivo mais de acalmar o efervescente MST, do que de uma estratégia de desenvolvimento territorial de âmbito nacional. No entanto, os dados sistematizados de São Paulo, apresentados no Gráfico 1, indicam que o período de 1995 e 1998 o maior número de implantações, principalmente na região oesteno Pontal do Paranapanema. As criações aumentam nesse período e começam a fortalecer as outras regiões.

Analisando o Gráfico 1, observa-se que aparentemente, antes desse período, foram criados assentamentos espalhados pelo Estado, mas a política de implantações retoma fôlego em 1995 e, em 2003, o II PNRA é promulgado no sentido de reafirmar a importância das criações. No entanto, o plano reestabelece metas, mas dá ênfase à disponibilização de políticas e recursos específicos por meio de programas, tendo como objetivo a manutenção 
das famílias no campo.

Nesse período, o Congresso Nacional, de maioria conservadora em relação à questão agrária, aprova duas leis para regulamentar o capítulo 184 da Constituição Federal que trata da Política Agrária. Marca, assim, mais uma vez, um avanço mais declarado do que praticado, reafirmando a importância de ordem econômica e não social.

Gráfico 1: Assentamentos criados 1985 a 2011 em São Paulo.

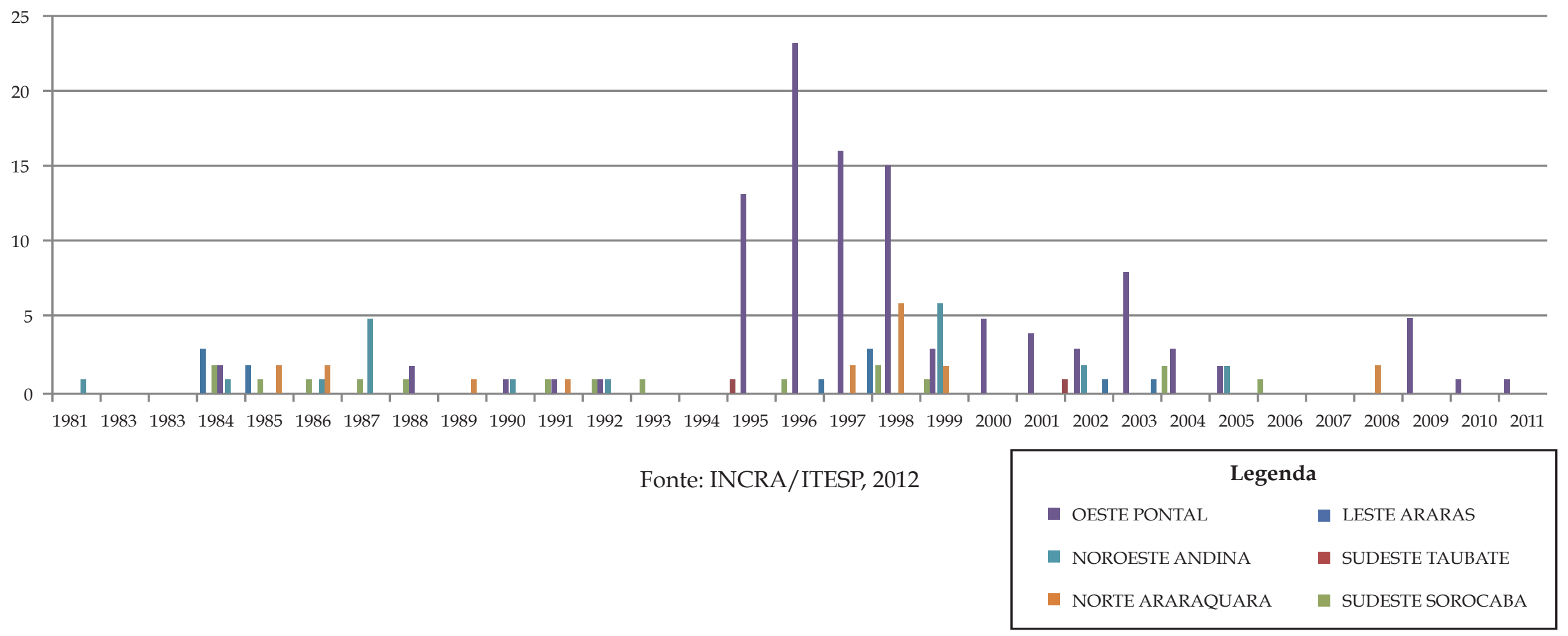


Durante os dois mandatos seguintes de Fernando Henrique Cardoso (1995/2003), podem ser destacados dois momentos - que coincidem com o fim de cada um. No primeiro, a reforma agrária aparecia no discurso do plano de governo, não como um plano específico; nesse momento a previsão era o assentamento de 280 mil famílias no país. A reforma agrária era justificada como forma de desenvolvimento da agricultura familiar e como solução do problema da segurança alimentar. Entretanto nos primeiros anos, a política praticada sinalizava a opção pelo modelo agroindustrial, inserido no contexto da política neoliberal que fragiliza a estrutura operacional do Estado.

Diante dessa condição, intensificou-se a organização dos movimentos sociais de trabalhadores rurais que, além de se manifestarem, ocuparam terras improdutivas, organizando acampamentos como estratégia de pressão para que se cumprissem as metas estabelecidas. Mais uma vez, há a tentativa de se acalmarem as tensões advindas do movimento social organizado. Sem um projeto para a reforma agrária, mas apoiado pelo Banco Mundial, o governo responde com a implantação do projeto piloto Programa Cédula da Terra, em alguns estados. Estabelece, então, uma reforma balizada em transações comerciais do mercado de terras, por meio do financiamento de imóveis rurais diretamente aos interessados. Resultante desse programa, a aprovação do Banco da Terra, em 1997, é a principal medida para aquisição de terras, substituindo as desapropriações para fins de reforma agrária.

Navarro (1998) sugere que se o programa tivesse sido efetivamente implantado poderia ter produzido lições operacionais e um aprendizado consistente, visando à sua possível extensão, posteriormente, ao restante do país. Poderia ser uma alternativa aos processos usuais de acesso à terra pela desapropriação de imóveis rurais por interesse social, e sua parcelização para famílias rurais sem terra, de acordo com as diretrizes legais vigentes. $\mathrm{O}$ autor intitula tal procedimento como "método tradicional". 
Concomitantemente, o movimento dos trabalhadores rurais se intensifica. No período foram realizadas ocupações de terras, das superintendências do INCRA, e a multiplicação dos acampamentos. Por fim, além da inserção de decretos e revisões na legislação vigente, reforçando o objetivo de que as ações dos trabalhadores rurais fossem contidas, o governo, com o apoio da mídia, promove a criminalização do movimento social, acirrando ainda mais a problemática em torno da reforma agrária. Durante esse período, os assentamentos rurais implantados completam a maioridade, mas não alcançam as metas propostas no primeiro Plano.

Em 2003, o início de um governo caracterizado pelo apoio aos movimentos sociais aumentou a expectativa em relação aos outros, o que não favoreceu a prática, pois vontade política não é suficiente para a implementação, que depende não só da legislação, mas também da capacidade operacional de seus administradores. Foi elaborado um plano de emergência, cuja meta era assentar 60 mil famílias de trabalhadores rurais. Essa meta não pôde ser atingida, diante do orçamento herdado do governo anterior que previa apenas o assentamento de 24 mil famílias.

Além da defasagem descrita, o ano do primeiro governo foi marcado pelo debate junto aos movimentos sociais organizados no Fórum Nacional de Reforma Agrária e Justiça no Campo, e nos fóruns estaduais para a elaboração do Novo Plano Nacional de Reforma Agrária. Ainda que o governo tenha investido na nomeação de intelectuais especialistas da problemática agrária, os contratempos e a falta de consenso marcaram o atraso da publicação do II PNRA. Dessa vez, foi considerada uma necessidade mexer na estrutura fundiária caracterizada pela concentração de terras. Nesse sentido, a desconcentração pretendida, por meio dos assentamentos, promoveria não só a multiplicação de produtores, o aumento da oferta de produtos agrícolas, o aumento do consumo e da circulação de riqueza no comér- 
cio local e regional, mas também garantiria uma melhor distribuição de renda e avanços na pretendida justiça social.

Os dados do último censo agropecuário do IBGE (2006) indicam que a agricultura familiar emprega 77\% da mão-de-obra do campo, sendo responsável, juntamente com os assentamentos, por 38\% do valor bruto da produção agropecuária e pela produção dos principais alimentos que compõem a dieta da população. A meta inicial proposta no II Plano era similar àquela fixada no I PNRA de 1985: o assentamento de 1 milhão de famílias em 4 anos. Pretendia-se colocar em prática o que já estava previsto em lei. Contudo, a meta proposta na elaboração do II PNRA não foi divulgada e, ainda assim, sofreu ajustes e cortes para readequar a proposta às possibilidades econômicas do país e, principalmente, para acomodar os interesses das forças políticas de composição do governo.

No final de 2003, foi anunciada a meta de 400 mil famílias a serem assentadas em duas etapas: até o final do mandato em 2006; e o assentamento de 120 mil famílias no ano de 2007.

A Tabela 1 apresenta o número de famílias e assentamentos criados por período de governo, bem como confirma a baixa efetividade entre as metas estabelecidas nos planos e a implementação. Ao que parece, no Plano, o desenho de uma paisagem rural reformada foi elaborada, mas ao final de cada governo as metas não estavam próximas de serem alcançadas. Apesar da fragilidade com que foram criados, os assentamentos rurais tornaram-se, parte da configuração do meio rural brasileiro, cada vez menos como ilhas esparsas entre os latifúndios monocultores. A figura 1 ilustra a espacialização dos assentamentos rurais no Brasil. 
Tabela 1: Assentamentos rurais criados no Brasil de 1985 a 2008

\begin{tabular}{|l|l|l|l|}
\hline \multicolumn{5}{|l|}{ IMPLANTAC̃A DE ASSENTAMENTOS RURAIS NO BRASIL } \\
\hline ANO & ASSENTAMENTOS & FAMÍLIAS & ÁREA (ha) \\
\hline $1985-1989$ & 825 & 125.106 & 8.358 .664 \\
\hline $1990-1994$ & 472 & 62.808 & 4.515 .090 \\
\hline $1995-2002$ & 3.924 & 393.731 & 20.466 .985 \\
\hline $2003-2008$ & 2.392 & 235.466 & 22.923 .929 \\
\hline TOTAL & 7.613 & 817.111 & 56.264 .668 \\
\hline
\end{tabular}

Fonte: Rocha, 2009.

Na prática, é possível perceber que o processo de distribuição de terras, por parte do Estado, tem sido demorado e tem comprometido os investimentos e recursos aplicados. Consequentemente, a implantação de assentamentos rurais não foi suficiente para conter os conflitos - grilagem e aumento do valor da terra - em relação ao uso da terra rural.

\subsection{Projeto de Assentamento Rural}

Os assentamentos rurais são parcelamentos destinados à produção da agricultura familiar por meio da distribuição de terras públicas. É uma área rural reconfigurada, resultante da espacialização de leis e planos que se materializam a partir através de programas e projetos. Podem ser executados por ações da esfera federal e também da estadual,

Figura 1: Assentamentos Rurais no Brasil 1985 - 1999

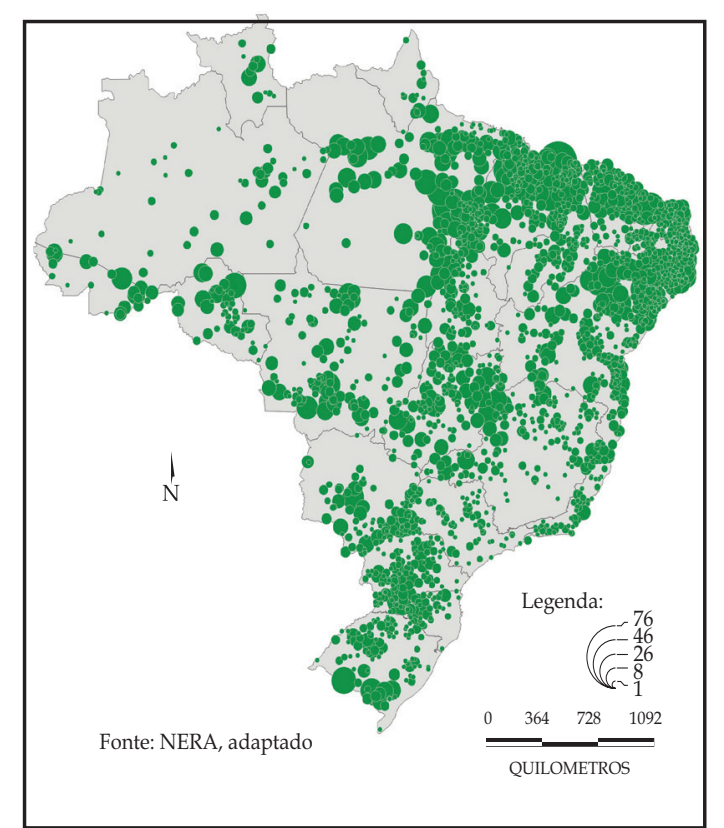


compreendendo ações em parceria, inclusive com outras instituições governamentais ou não-governamentais. Enquanto forma de ocupação, o assentamento representa um tipo de espacialização presente no desenvolvimento do país nos últimos trinta anos.

O INCRA, em São Paulo representado pela Superintendência Regional de São Paulo (SR08), e a Fundação Instituto de Terras do Estado de São Paulo (ITESP) são os executores do programa de reforma agrária em vigor no país. Para esta pesquisa foram identificados diferentes tipos assentamentos rurais organizados em modalidades de assentamentos implantados a partir do Programa de Reforma Agrária destacados no Quadro 1.

Quadro 1: Tipo de assentamento rural implantado em São Paulo - 1985 - 2013

\begin{tabular}{|l|l|l|}
\hline SIGLA & TIPO DE PROJETO & MODALIDADE \\
\hline PA & Projeto de Assentamento Federal & Atual Gov. Fed. \\
\hline PDS & Projeto de desenvolvimento Sustentável & Atual Gov. Fed. \\
\hline PE & Projeto de Assentamento Estadual & Atual Estado \\
\hline
\end{tabular}

Fonte: Rocha, 2009. (Adaptado)

Dos tipos de projetos de assentamentos identificados no estado de São Paulo, 29,4\% foram criados pelo INCRA em períodos anteriores ao II PNRA e que, atualmente, são modalidades que estão fora de vigência. Outros 29,4\% também foram constituídos pelo INCRA, porém foram implantados depois do II PNRA: na época foram chamados "atual governo federal". Do total, quase 17,5\% são reconhecidos pelo INCRA como beneficiários da reforma agrária; e 23,5 \% foram assentamentos implementados pelo governo do Estado, chamados "Atual Estado"

Essas implantações podem ocorrer em áreas que, ou estavam sob domínio do Estado, 
ou então são constituídas por terras públicas, ou ainda áreas arrecadadas em ações reivindicatórias $^{8}$, obtidas por desapropriação ou aquisição federal (ROCHA, 2009). O principal critério, adotado em São Paulo, para classificar uma área como passível de assentamento é o não cumprimento de sua função social, conforme estabelecido no Estatuto da Terra, anteriormente mencionado.

O assentamento é a base sobre a qual serão materializadas as políticas e os programas disponibilizados para promover a subsistência e o desenvolvimento dos trabalhadores rurais nessa nova ocupação. É a partir do acesso à terra que as famílias passam a ter os meios de produção e habitação. Embora as definições que constituem o assentamento estejam embasadas em parâmetros técnicos, esse espaço tem como premissa a atuação participativa das famílias que vão viver ali, não sendo o assentamento apenas a implantação de fazendas estatais de produção. A intenção do projeto para o assentamento rural é a construção de comunidades de agricultores familiares autônomos, autogestionários e contribuidores do desenvolvimento econômico regional.

Para Marques (2000), o projeto de assentamento como espaço de ressocialização é formado por um conjunto de ações técnicas que resultam na concepção do Projeto de Assentamento a partir da incorporação de um conteúdo novo no espaço abstrato. A construção do assentamento implica a construção do assentado.

Segundo Stédile a reforma agrária:

[...] não deve mais ser vista como uma disputa entre sem terras e latifundiários e, sim, como uma disputa do povo brasileiro, da classe trabalhadora, contra a aliança dos fazendeiros, dos grandes proprietários de terras com as empresas transnacionais do agronegócio e dos bancos. (REVISTA STOPIM, 2012, entrevista com João Pedro Stédile)
${ }^{8}$ De acordo com o código civil, o proprietário pode reaver sua propriedade do poder de quem a possui ou detenha de maneira injusta. 
Assim, o projeto de assentamento rural é o instrumento e o resultado da espacialização das políticas inseridas no Programa Nacional de Reforma Agrária, é um parcelamento direcionado para as famílias de trabalhadores rurais que não têm acesso à terra. A reorganização fundiária gerada com a materialização do projeto constitui o parcelamento de uma fazenda em lotes menores implicando a alteração da densidade construtiva e populacional e alterando as características físicas e sociais da área ocupada. No lugar de um proprietário, em uma extensão de terra são assentadas famílias em porções menores.

A aplicação desse instrumento não é simples, pois depende de uma articulação de ações para que as normas e diretrizes se materializem, construindo o assentamento. As articulações e as ações estabelecidas, tanto na escala federal quanto na estadual, regem a materialização do assentamento, mas os impactos socioeconômicos são dados em escala municipal. Por isso, depois do II PNRA as ações foram descentralizadas e escritórios locais com técnicos de campo foram inaugurados para o atendimento e a orientação das famílias em regiões específicas.

Atualmente, a possibilidade de ser um assentado da reforma agrária em um projeto de assentamento rural depende do preenchimento de alguns requisitos legais. Os candidatos a beneficiários são selecionados, pelos critérios definidos na legislação agrária, regulamentada por normas internas do INCRA como a Norma de execução n45/2005 (INCRA 2005) a qual define os requisitos legais para ser beneficiários da Reforma Agrária, a saber:

a. possuir conjunto familiar que aufira renda proveniente de atividade não agrícola inferior a três salários mínimos mensais;

b. não ser funcionário público de qualquer esfera ou poder; 
c. não ser proprietário, quotista, acionista ou co-participante de estabelecimento comercial ou industrial;

d. não ser ex-beneficiário ou beneficiário de regularização fundiária executada direta ou indiretamente pelo INCRA, ou de projetos de assentamento oficiais ou outros assentamentos rurais de responsabilidade de órgãos públicos, salvo por separação judicial do casal ou outros motivos justificados;

e. não ser proprietário de imóvel rural com área superior a um módulo rural;

f. não ser portador de deficiência física ou mental, cuja incapacidade o impossibilite totalmente para o trabalho agrícola;

g. não ser estrangeiro não naturalizado;

h. não ser aposentado por invalidez;

i. não estar condenado por sentença final definitiva transitado em julgado com pena pendente de cumprimento ou não prescrita, salvo se o candidato fizer parte de programa de recuperação e reeducação social.

Nas normas, o INCRA define o projeto de assentamento rural como:

Um conjunto de ações, em área destinada a reforma agrária, planejadas, de natureza interdisciplinar e multissetorial, integradas ao desenvolvimento territorial e regional, definidas com base em diagnósticos precisos acerca do publico beneficiário e das áreas a serem trabalhadas, orientadas para utilização racional dos espaços físicos e dos recursos naturais existentes, objetivando a implementação dos sistemas de vivencia e produção sustentáveis, 
na perspectiva do cumprimento da função social da terra e da promoção econômica, social e cultural do (a) trabalhador (a) rural e de seus familiares. (INCRA, 2000).

Para o MST, o assentamento é definido como espaço de vida, trabalho e produção de um conjunto de famílias. Para eles, a vida no assentamento garante às famílias direitos sociais como a casa, a escola e a comida. Consideram que o impacto do assentamento no município é econômico e social, pois a estrutura da terra é reformada para que desempenhe sua função social. Nesse momento, são disponibilizados instrumentos para que as famílias possam se estabelecer e se desenvolver no sentido de produzir alimentos (ROCHA, 2009 p. 12).

O assentamento, enquanto o retrato físico da reforma agrária, tem início com a emissão da posse por parte do INCRA, quando recebe a terra legalmente para depois transferir para as famílias beneficiárias, a fim de que a cultivem e promovam seu desenvolvimento econômico. As principais funções dos Projetos de Assentamento de Reforma Agrária são: promover a inclusão social do trabalhador rural e seus familiares; o cumprimento da função social da propriedade e garantir a fixação do homem no campo. Sua constituição é resultante do processo de conquista do território dos assentamentos que, segundo Rocha (Ibid.), contempla várias datas, desde a ocupação da terra, a obtenção e, por fim, a criação do assentamento, demonstrando a diferença e a interação entre a luta pela terra e a política de reforma agrária. As formas de obtenção de terra mais verificadas em São Paulo são: a compra e a desapropriação (ROCHA, 2009, p. 12).

No entanto, quando criado o projeto do assentamento, ao mesmo tempo em que é provocado um investimento por parte do Estado, são criadas outras carências diretas ao público assentado, como por exemplo, escolas, estradas e transporte, saúde, água, energia 
elétrica, assistência técnica, etc. Dessa maneira, tem início uma nova problemática instituída para o assentado, sendo a criação do Projeto de Assentamento apenas o começo (GUANZIROLI, 1999). Para o ITESP, o assentamento rural é como o projeto de um novo bairro rural, uma nova comunidade na qual os trabalhadores rurais sem-terra tornam-se agricultores familiares, que poderão contribuir para o desenvolvimento regional. Por isso, o assentamento deve oferecer condições para que as famílias sobrevivam e se desenvolvam em uma nova comunidade (ITESP, 1997).

Considerando a problemática apresentada e o cenário no qual foram criados e constituídos os projetos de assentamentos rurais de reforma agrária no Brasil, apresenta-se, a seguir, uma aproximação das implantações ocorridas no Estado de São Paulo em busca de identificar e reconhecer as resultantes de implantação dessas experiências. Entende-se também, nesse contexto, que o assentamento pode ser reconhecido enquanto lugar de moradia, inserido na zona rural, implantado como estratégia de diminuição da pobreza no país.

\subsection{Politicas e programas para assentamentos rurais}

Para aprofundar o estudo sobre o projeto e a implantação dos assentamentos rurais, uma pesquisa foi realizada no âmbito do Estado de São Paulo. O mosaico de formas e usos que compõem o meio rural paulista é variado e pode ser percebido nos percursos que levam ao interior. Além dos novos usos, que modificaram a interface urbana rural de alguns municípios, são verificados no território diferentes tipos de comunidades rurais. São ambientes construídos, resultantes das práticas do cotidiano que moldam a paisagem rural. Podem ser organizados de forma espontânea, promovidos ou reconhecidos pela iniciativa pública. 
Em 2008, o Governo Federal lançou o programa Territórios da Cidadania, que tem como objetivo a promoção do desenvolvimento econômico e o acesso à cidadania como estratégia de desenvolvimento territorial. As ações previstas consideram a participação da população, dos estados e dos municípios. No levantamento realizado pelo programa, foram demarcados 120 territórios no país, três deles em São Paulo: Pontal do Paranapanema, Sudoeste Paulista e Vale do Ribeira. A demarcação dos territórios foi feita a partir da identificação do acesso ao conjunto de ações e programas já disponibilizados pelas instâncias governamentais. São apoiadas atividades vinculadas às questões produtivas, de cidadania, de direitos e que promovam a melhoria da infraestrutura instalada. Entende-se que a política pública é uma diretriz inserida no planejamento de ações que se concretizam com a elaboração de programas mais específicos para atender às demandas da população.

Observa-se, a partir de 2003, um avanço de políticas sociais, como a Política dos Territórios Rurais e o Bolsa Família, organizados em programas que tiveram impacto sobre o modo de vida nas regiões predominantemente rurais. Até então, não havia uma política social que criasse oportunidade para que as famílias rurais, descapitalizadas, construíssem ou reformassem suas casas. Antes disso, as moradias nos assentamentos rurais eram construídas com recursos provenientes do Crédito Instalação, concedido desde 1985 para instalação e desenvolvimento inicial da vida no assentamento.

Desde 1985, com a implantação dos primeiros assentamentos, o crédito instalação - na modalidade de aquisição de materiais de construção - foi a única iniciativa voltada à provisão de moradia nos assentamentos rurais. Em 2003, a criação da Política Nacional de Habitação Rural, que aparece como uma derivação dos modelos de provisão de moradia urbana, foi resultado de uma articulação - entre atores, setores e ações - mais efetiva do que de as iniciativas anteriores. 
O objetivo destes programas é suprir as necessidades básicas, fortalecer as atividades produtivas, desenvolver os projetos, auxiliar na construção de unidades habitacionais e atender necessidades hídricas das famílias dos projetos de assentamento. O Crédito Instalação é concedido nas seguintes modalidades: Apoio Inicial; Apoio Mulher; Aquisição de Materiais de Construção; Fomento; Adicional Fomento; Semiárido; Recuperação/Materiais de Construção; e Crédito Ambiental. (INCRA, 2012).

\subsection{Habitação Rural}

A execução do Programa de Crédito Instalação depende de uma equipe multidisciplinar, com técnicos locados nas Superintendências Regionais (SR) e nas Unidades Avançadas (UA) do INCRA, estrategicamente localizados nas regiões caracterizadas pela presença dos assentamentos. Para o acesso ao crédito, não há necessidade de projeto para a construção da casa: a aplicação dos recursos realiza-se com a participação de associações ou representantes dos assentados, orientados pela assessoria técnica. Vale ressaltar que, nem sempre - ou quase nunca - esse técnico tem formação na área da arquitetura e que o pagamento das aquisições é feito diretamente ao fornecedor - mercados locais, lojas de material de construção e de implementos agrícolas. Na Tabela 2 pode-se observar a modalidade e o valor do crédito disponível por família.

No ano seguinte à organização do Programa Nacional de Habitação Rural (PNHR) ${ }^{9}$, organizado a partir da Resolução 460 do Conselho Curador do Fundo de Garantia por Tempo de Serviço (CC FGTS), o Programa de Aceleração do Crescimento (PAC) engloba as ações 
habitacionais - urbanas e rurais - e, outra vez, em menos de um ano, lança um programa. As diretrizes da política Nacional são transformadas no Programa Minha Casa Minha Vida de 2009 (PMCMV). Nesse primeiro momento, o público dos assentamentos ficou excluído do programa; porém, em documento publicado em 2013, o INCRA anuncia o déficit habitacional rural no Brasil de 916 mil unidades, e indica que nas áreas de reforma agrária a meta é construir 130 mil unidades habitacionais até 2014, das quais mil deverão ser construídas nos assentamentos rurais paulistas. (BRASIL, 2013)

Durante esse período, o público residente nos assentamentos rurais contou com as ações do programa de reforma agrária que incluíam recursos específicos para provisão da moradia. A publicação da norma de execução, NE nº 54 (INCRA, 2009), considera a necessidade de revisão dos valores referentes ao Crédito Instalação, modalidade de aquisição de material de construção, e aumenta o valor disponível para as famílias construírem suas ca-

Tabela 2: Modalidades e valores do crédito instalação

\begin{tabular}{|l|l|}
\hline Apoio Inicial & $\mathrm{R} \$ 3,2 \mathrm{mil}$ \\
\hline Apoio Mulher & $\mathrm{R} \$ 2,4 \mathrm{mil}$ \\
\hline Aquisição de Materiais de Construção & $\mathrm{R} \$ 15 \mathrm{mil}$ \\
\hline Fomento & $\mathrm{R} \$ 3,2 \mathrm{mil}$ \\
\hline Adicional do Fomento & $\mathrm{R} \$ 3,2 \mathrm{mil}$ \\
\hline Semiárido & Até $\mathrm{R} \$ 2$ mil \\
\hline Recuperação / Materiais de Construção & Até $\mathrm{R} \$ 8$ mil \\
\hline Reabilitação de Crédito de Produção & Até $\mathrm{R} \$ 6$ mil \\
\hline Crédito Ambiental & $\mathrm{R} \$ 2,4$ mil \\
\hline
\end{tabular}

Fonte: INCRA, 2012.

${ }^{9}$ Regulamentado pela Portaria n. ${ }^{\circ} 326$ de 31 de agosto de 2009. 
sas. Demonstra-se assim que há uma sequência de ações, por parte do governo, na tentativa de responder às demandas sociais, organizadas e representadas por movimentos sociais há 27 anos. Mas, ao que parece, o tempo entre uma e outra ação não tem sido suficiente para aprimorar os formatos, os instrumentos e as formas de operacionalização, o que tem prejudicado o beneficiário e o atendimento das metas propostas.

Considerando-se que, no primeiro momento, o PMCMV Rural não atendeu as famílias dos assentamentos rurais, a PNHR foi tomada como ponto de observação, pois o acesso a novas condições de moradia é fator de melhoria da qualidade de vida e tem impacto nas dinâmicas de desenvolvimento rural. O PNHR pode ser visto como mais um componente das ações trabalhadas para a promoção de um desenvolvimento rural integrado e duradouro (ROVER, 2010).

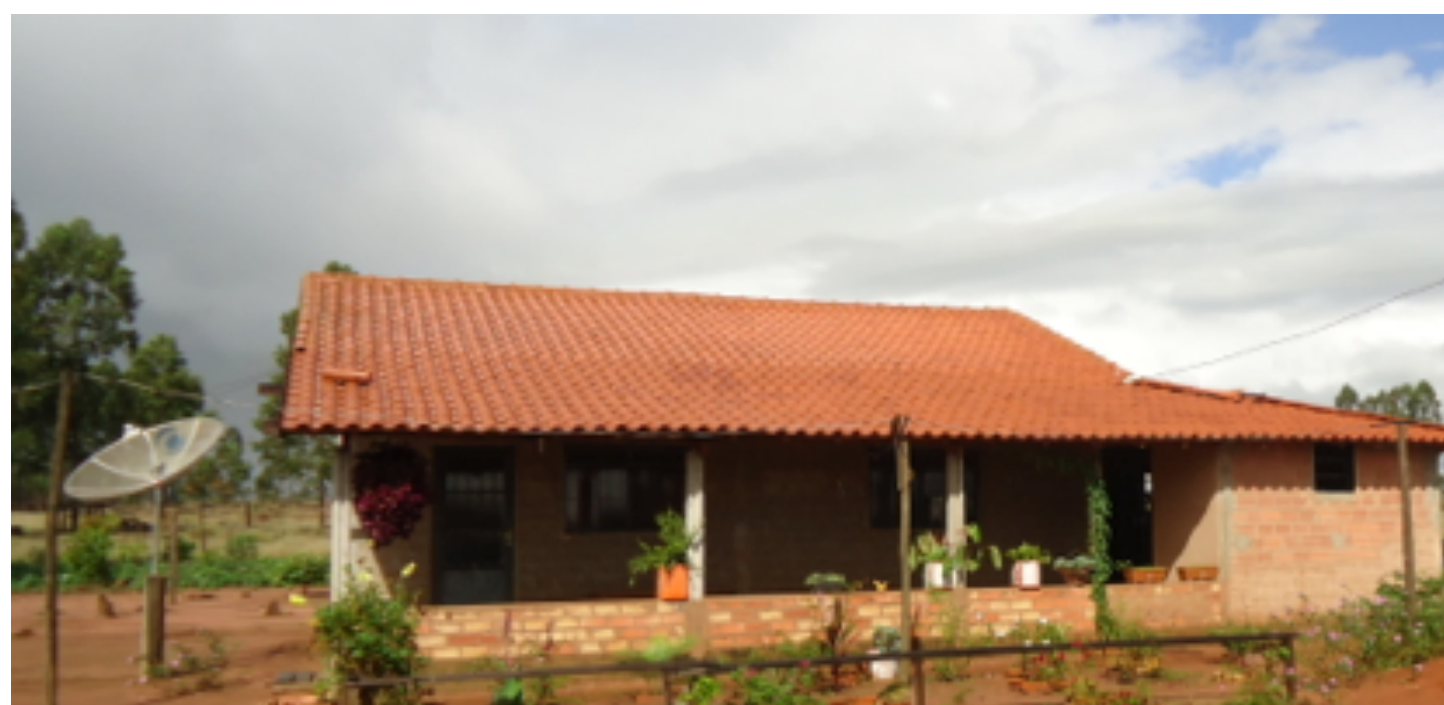

Foto 1: foto registrada pela autora - unidade habitacional assentamento Zumbi dos Palmares - Iaras/SP, 2013. 
Imprimindo outra direção na forma de provisão de moradia no meio rural, a PNHR não se apresenta como estratégia nacional; tem como objetivo subsidiar a construção ou reforma das unidades habitacionais de agricultores familiares e trabalhadores rurais, intermediadas por operações de repasses de recursos do Orçamento Geral da União ou de financiamento habitacional com recursos do Fundo de Garantia por Tempo de Serviço - FGTS.

É por meio da Portaria n ${ }^{\circ}$ 406, de 02 de setembro de 2011 (BRASIL, 2011) que são definidas as diretrizes e as condições operacionais do Programa (PNHR), e definidas as especificações mínimas. Trata-se de uma política social que cria oportunidade para as famílias rurais descapitalizadas construírem ou reformarem sua casa.

Ainda que seja restrita, diante das exigências financeiras e da operação dos créditos, a oportunidade é marcada pela contradição no formato de operacionalização e nas tipologias disponibilizadas para as unidades habitacionais, que indicam características muito mais urbanas do que rurais. Ainda assim, indica o reconhecimento, por parte da União, do déficit histórico constituído pela problemática do direito à moradia, seja ela urbana ou rural, inserida na problemática do direito à propriedade da terra.

As políticas e os programas disponibilizados ao meio rural no Brasil até 2003 estiveram voltados à produção e à produtividade; não alcançavam as questões da moradia, que não aparecia nem nos discursos e nem nas pautas de reivindicação dos movimentos de luta do meio rural. A demanda do movimento social do campo é o direito de acesso à terra para nela viver e trabalhar. Assim, o direito à moradia aparece como incluído na entrada da terra, o que talvez explique por que a moradia rural tenha sido pouco estudada do ponto de vista da construção, e da tipologia inserida no contexto específico dos assentamentos rurais.

O Programa PNHR, criado em 2003, foi composto por três modalidades de contrato 
com o objetivo atender as famílias com renda entre um e três salários mínimos ${ }^{10}$ :

a) Programa de Subsídio à Habitação de Interesse Social (PSH);

b) Carta de Crédito com Operações Coletivas - FGTS (CCFGTS);

c) Crédito Solidário (FDS)

As modalidades " $a$ " e " $b$ " constituíram experiências de construção e reforma de moradia nos assentamentos. A modalidade "a" foi experimentada de forma pontual, num ou noutro assentamento, enquanto a modalidade " $b$ " serviu de base para organizar a operacionalização do Programa de Moradia Rural (PMR), implantado em São Paulo a partir de 2006.

O PNHR faz referência ao valor do subsídio do CC FGTS, de acordo com a faixa de renda:

\begin{abstract}
I) para o agricultor cuja renda mensal é até um salário mínimo, o subsídio é de $\mathrm{R}$ \$ 5.907, ficando o restante da obra sob sua responsabilidade;

II) para o agricultor cuja renda mensal seja maior que $\mathrm{R} \$ 930$ e menor que $\mathrm{R} \$$ 1.500 , o subsídio é de $\mathrm{R} \$ 3.000$, sendo que o restante poderá ser financiado em até 96 meses. (ROVER; MUNARINI, 2010)
\end{abstract}

Essa formatação do Programa funcionou até 2009 quando, pelo Decreto Federal n. 6.819, novas regras foram instituídas. Apresentaram-se, então, mudanças significativas, principalmente porque o Decreto propõe superar o fator de maior dificuldade de enquadramento para os agricultores com maior vulnerabilidade socioeconômica: a exigência de contrapartidas financeiras.
10 Definido em R\$ 690,00 pela Lei Estadual $\mathrm{n}^{\mathrm{o}}$ 14.693, de 01.03.2012. 
O PNHR 2009 prevê que os beneficiários sejam agricultores familiares, enquadrados por grupos conforme renda anual para determinação dos valores liberados e os subsídios. Essa organização segue a mesma do Programa Nacional de Agricultura Familiar (PRONAF), agilizando processos e aproveitando uma sistemática consolidada. Esse tipo de proposta foi defendida não só pelas organizações de agricultores familiares, como também por estudiosos do assunto (SILVESTRO et al., 2001).

Mesmo com a mudança, a proposta não deu conta de atender a demanda que se manteve reprimida, principalmente pela falta do recurso de contrapartida por parte do beneficiário. Apesar disso, ela aponta caminhos para a solução desses limites, na medida em que amplia a faixa de subsídio, exigindo menos contrapartida das famílias mais vulneráveis socioeconomicamente. No entanto, esse novo formato ainda não permite avaliações mais consistentes de sua implementação (ROVER; MUNARINI, 2010).

Vê-se que as primeiras iniciativas de articulação entre atores, setores e ações para a provisão de moradia rural foram exíguas até a constituição do PNHR, acompanhado do avanço em outras políticas sociais, como a Política dos Territórios Rurais, que tiveram impacto sobre as regiões predominantemente rurais. Percebe-se que há uma tentativa de avanço na regulamentação de procedimentos e diretrizes que viabilizem a construção de unidades habitacionais no meio rural, mas o caráter emergencial no qual são implementadas gera roteiros de operacionalização que inviabilizam o alcance de resultados por parte da iniciativa anterior, gerando um acumulado de experiências inacabadas. 


\section{Capítulo 2}

\section{Ocorrências em SP}

\subsection{Ações federais e estaduais}

O conhecimento e a pesquisa a respeito dos projetos de assentamentos rurais de reforma agrária nos diferentes estados e regiões do Brasil é uma ocorrência recente na história nacional, principalmente no âmbito da arquitetura e do urbanismo. A implantação de assentamentos rurais nos últimos 20 anos, talvez seja, como aponta MITIDIERO (2011), um dos eventos mais marcantes da nossa formação territorial contemporânea, ao lado da ampliação acelerada das monoculturas de exportação comandada pelo agronegócio. Esses assentamentos deveriam ter infraestrutura e condições adequadas para as práticas de um cotidiano que envolve não só atividades vinculadas ao trabalho na terra, mas principalmente a gestão de políticas públicas orientadas para a promoção e fixação dessas famílias, evitando que o assentamento se desenvolva como uma favela do meio rural. A precariedade das condições de trabalho e moradia nos assentamentos remete a esse futuro se o assentamento não for objeto de estudo e trabalho de arquitetos e urbanistas. Para o autor o Estado é quem dita os passos e as técnicas para o assentamento das famílias.

É nesse processo que os problemas toma corpo, como por exemplo: morosidade no processo de desapropriação; lentidão das demandas que se dão no âmbito judicial; demora na demarcação dos lotes, construção das casas; lentidão na materialização de outras infraestruturas necessárias; descompasso no sistema de créditos e fragilidade - quando existem - dos programas de 
assistência técnica e assistência `a comercialização, o que dificulta efetivamente a construção do assentamento em uma área de produção agropecuária (MITIDIERO, 2011).

Verifica-se que em São Paulo foram implantados, desde 1985, aproximadamente 230 assentamentos rurais (ROCHA, 2009), os quais podem ser identificados por sua diretriz de projeto, são reconhecidos como: Projeto de Assentamento (PA); Projeto de Desenvolvimento Sustentável (PDS); e Projeto Estadual (PE).

Além dos diferentes programas, existem condições diferenciadas que são determinantes da forma como o projeto vai se materializar. Pode-se dizer que o projeto de vida do grupo será determinante - individual ou coletivo - da forma do parcelamento. Em suas considerações sobre a materialização dos assentamentos rurais de reforma agrária no Brasil Mitidiero afirma que:

\begin{abstract}
Mesmo que as informações sobre a situação socioeconômica dos assentamentos rurais não sejam empolgantes, mesmo que insucessos produtivos marquem muitos desses assentamentos, é inegável que a sua materialização em diferentes unidades da federação trouxe impactos territoriais de escala local e até regional. (MITIDIERO, 2011).
\end{abstract}

No quadro 2 estão detalhadas as ditetrizes para cada tipo de projeto identificado no Estado e na tabela 3 estão os números levantados com a pesquisa sobre as implantações paulistas.
Tabela 3: Tipos de projetos em SP

\begin{tabular}{|l|l|}
\hline PA PE & 220 \\
\hline PDS & 10 \\
\hline TOTAL & 230 \\
\hline
\end{tabular}

Fonte: elaborado pela autora com base em levantamento de campo, 2013. 
Quadro 2: Projetos de assentamentos rural

\begin{tabular}{|c|c|c|}
\hline A & $\begin{array}{l}\text { Projeto de } \\
\text { Assentamento } \\
\text { Federal }\end{array}$ & $\begin{array}{l}\text { Obtenção da terra, criação do Projeto e seleção dos beneficiário é de responsabilidade da União através do } \\
\text { INCRA; } \\
\text { Aporte de recursos de crédito Apoio a Instalação e de crédito de produção o (PROFNAF A e C) de respon- } \\
\text { sabilidade da União; Infraestrutura básica (estradas de acesso, água e energia elétrica de responsabilidade da } \\
\text { União; } \\
\text { Titulação (Concessão de uso/titulo de propriedade) de responsabilidade da União } \\
\text { Legislação: (INSTRUÇÃO NORMATIVA No. 15, de } 30 \text { de março de 2004, art. 3o) }\end{array}$ \\
\hline B & $\begin{array}{l}\text { Projeto de } \\
\text { Desenvolvim- } \\
\text { ento Susten- } \\
\text { tável }\end{array}$ & $\begin{array}{l}\text { Modalidade de projeto criada para o desenvolvimento de atividades ambientalmente diferenciadas, desti- } \\
\text { nado `as populações que baseiam sua subsistência no extrativismo, na agricultura familiar e em outras ativi- } \\
\text { dades de baixo impacto ambiental; } \\
\text { Obtenção da terra, criação do Projeto e seleção dos beneficiário é de responsabilidade da União através do } \\
\text { INCRA; } \\
\text { Aporte de recursos de crédito Apoio a Instalação e de crédito de produção (PROFNAF A) de responsabili- } \\
\text { dade da União; } \\
\text { Infraestrutura básica (estradas de acesso, água e energia elétrica de responsabilidade da União; Não há indi- } \\
\text { vidualização das parcelas (Titulação coletiva - fração ideal) e a titulação é de responsabilidade da União; } \\
\text { Legislação: Portaria/INCRA/PNo.477, de } 4 \text { de novembro de } 1999 \text {. }\end{array}$ \\
\hline C & $\begin{array}{l}\text { Projeto de } \\
\text { Assentamento } \\
\text { Estadual }\end{array}$ & $\begin{array}{l}\text { Obtenção da terra, criação do Projeto e seleção dos beneficiário é de responsabilidade das Unidades Federa- } \\
\text { tivs; Aporte de recursos de crédito e infraestrutura de responsabilidade das Unidades Federativas segundo } \\
\text { seus programas fundiários; } \\
\text { Há a possibilidade de participação da União no aporte de recursos relativos a obtenção de terras, Crédito } \\
\text { Apoio a Instalação e produção (PRONAF A) mediante convênio; } \\
\text { Há a possibilidade de participação da União no aporte de recursos relativos `a infraestrutura básica; } \\
\text { O INCRA reconhece os Projetos Estaduais como Projetos de Reforma Agrária viabilizando o acesso dos ben- } \\
\text { eficiários aos direitos básicos estabelecidos no Programa de reforma Agrária. Titulação de responsabilidade } \\
\text { das Unidades Federativas. } \\
\text { Legislação: NORMA DE EXECUÇÃO INCRA No 37, de } 30 \text { de março 2004. }\end{array}$ \\
\hline
\end{tabular}


Na figra 2, as implantações no Estado de São Paulo estão indicadas por tipo de projeto. Estão inseridos em regiões identificadas e reconhecidas pela concentração de assentamentos. No extremo oeste estão concentrados os Projetos Estaduais, implantados a maioria no Pontal do Paranapanema, foram as primeiras experiências registradas em São Paulo; Projetos Federais concentrados na região de Andradina e Pereira Barreto e distribuídos ao longo do eixo da rodovia Anhanguera destacando a região de Sorocaba, Promissão e Iaras. As experiências mais recentes são as implantações de Projetos de Desenvolvimento Sustentável, tornaram-se característicos dos Vales do Paraíba e do Ribeira.

O PDS é um programa que se diferencia por ser concretizado a partir de um projeto comum às famílias, adequado às condições locais. De acordo com o levantamento no INCRA de São Paulo ${ }^{9}$, esse tipo de projeto passa a fazer parte do meio rural paulista, a partir de 2010, como alternativa para tentar evitar os problemas verificados nos programas tradicionais - principalmente a venda de lotes - que fragilizam a área recém reformada.

A implantação de um assentamento, seja ele federal ou estadual, segue diretrizes organizadas por normas técnicas ou decretos que determinam a metodologia de criação para o projeto. O tamanho do lote é uma relação pelo módulo rural, definição mínima da área do lote rural definida por município, considerando o tamanho das famílias e a força de trabalho disponível. Em São Paulo, os lotes com áreas menores que o módulo rural, são chamados de pararrural.

Na fiugra 3 estão indicadas as implantações de assentamentos rurais e federais no extremo oeste de São Paulo. 


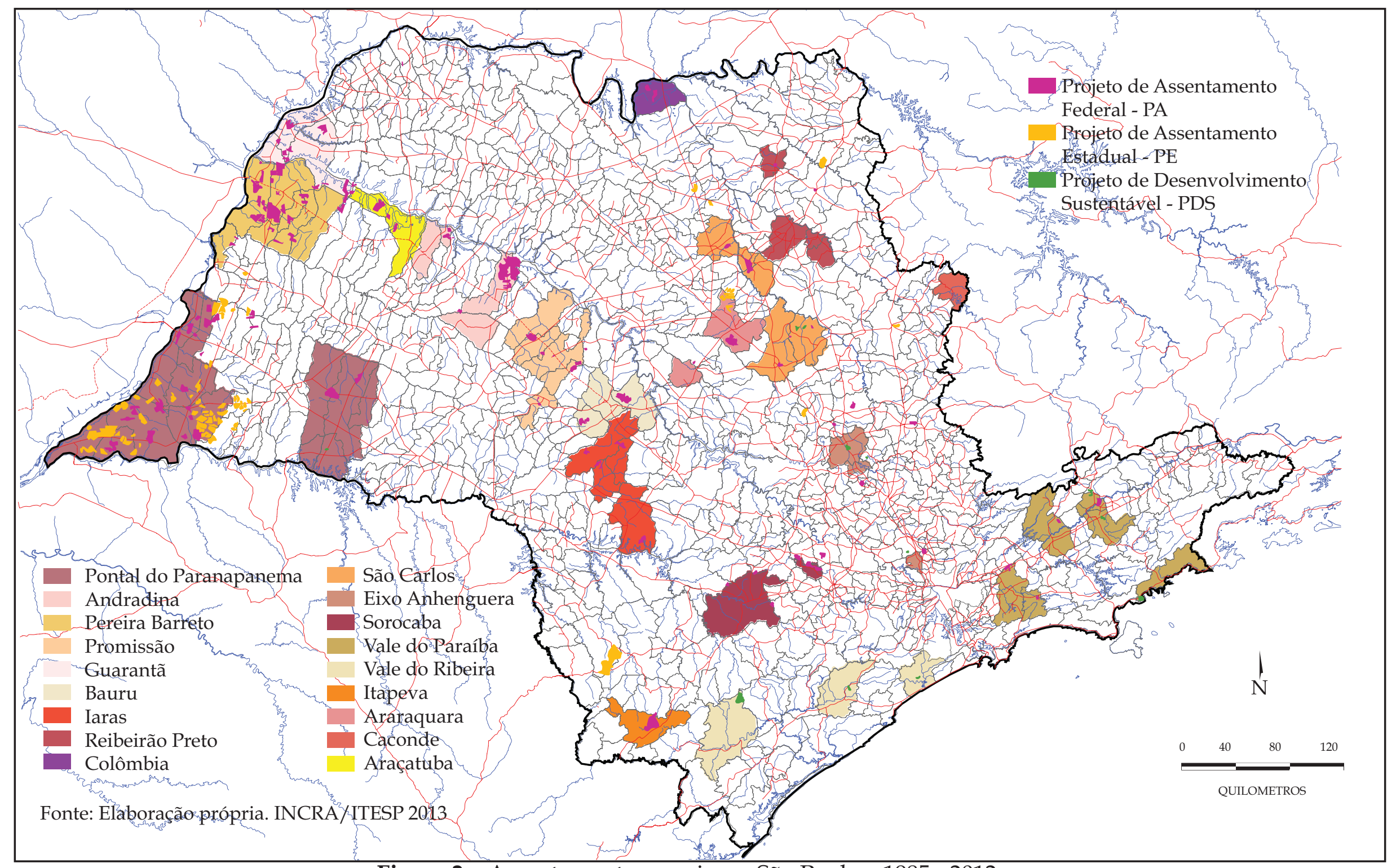

Figura 2: Assentamentos rurais em São Paulo - 1985 - 2012 
O INCRA reconhece os PE como projetos de reforma agrária, mesmo que para esse tipo de projeto não esteja prevista a titulação da terra ao beneficiário. A principal diferença entre o PA e os outros dois tipos - PE e o PDS - é que, no primeiro, o beneficiário tem direito ao título de propriedade, enquanto os outros dois não têm previsão de titulação da terra.

Os dados sistematizados no gráfico 2 indicam a origem da terra nas regiões identificadas. Na região do oeste do Pontal do Paranapanema, ao contrario do que acontece em Andradina - duas regiões caracterizadas pela presença dos assentamentos - todos os assentamentos implantados foram organizados pelo ITESP em terras estaduais devolutas da união, processo que marcou os anos 1990.

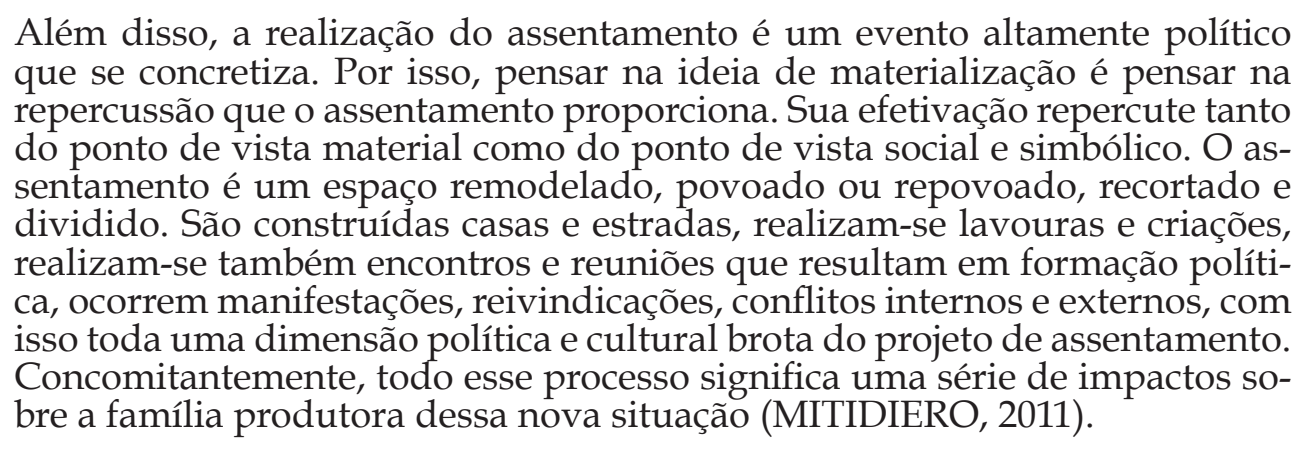

Conhecida como terra do nelore devido à forte presença do que se denominou capital pecuário, a região do Pontal do Paranapanema é marcada por uma situação de indefinição da estrutura fundiária, pois ainda tem ações discriminatórias em andamento na justiça paulista, apontando novas intervenções públicas no sentido da criação de novos assentamentos. (FERRANTE, BARONE, et al., 2012).
Gráfico 2: Origem da terra por região - SP

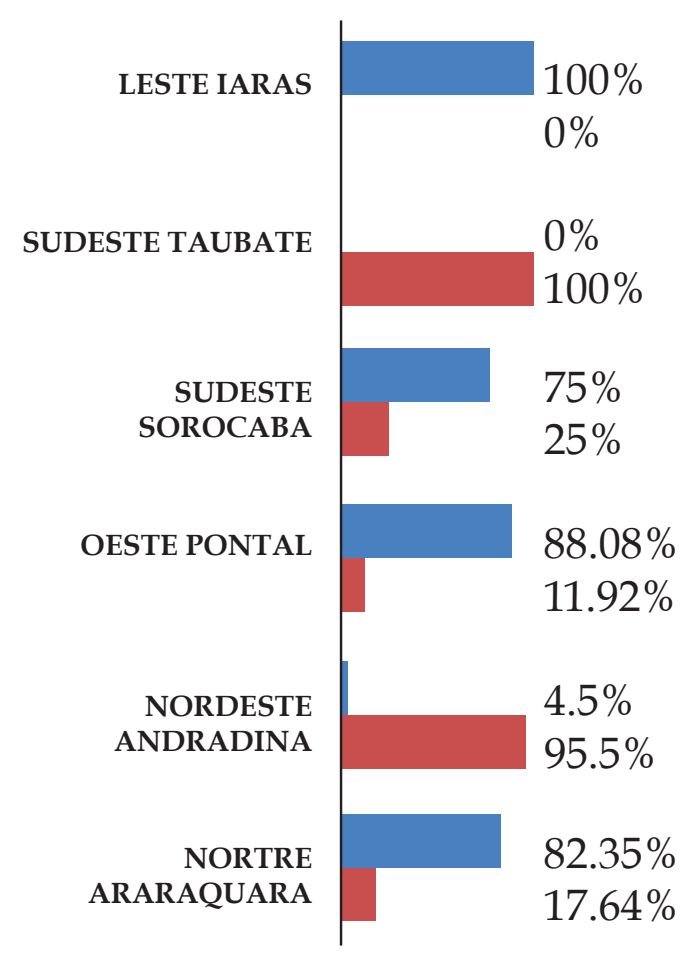

Estadual Federal

Fonte: elaborado pela autora com base no levantamento no INCRA e no ITESP, 2013. 


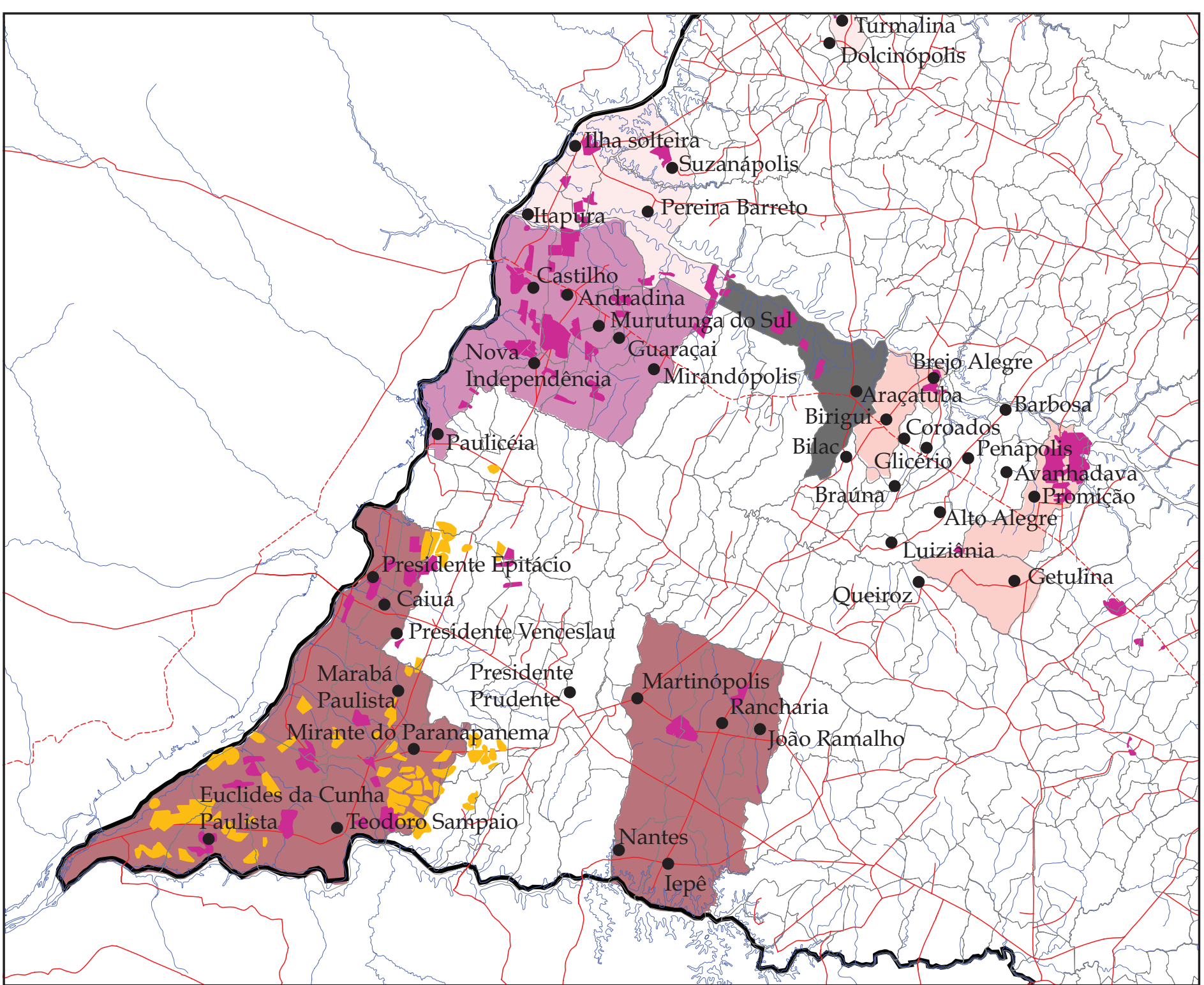

Figura 3: Assentamentos rurais no Pontal do Paranapanema e em Andradina.

\section{Legenda}

Projeto Assentamento Estadual ITESP

Projeto Assentamento Federal INCRA

Pontal do Paranapanema

Andradina

Prereira Barreto

Araçatuba

Promição

— Vias

— Rios e corregos
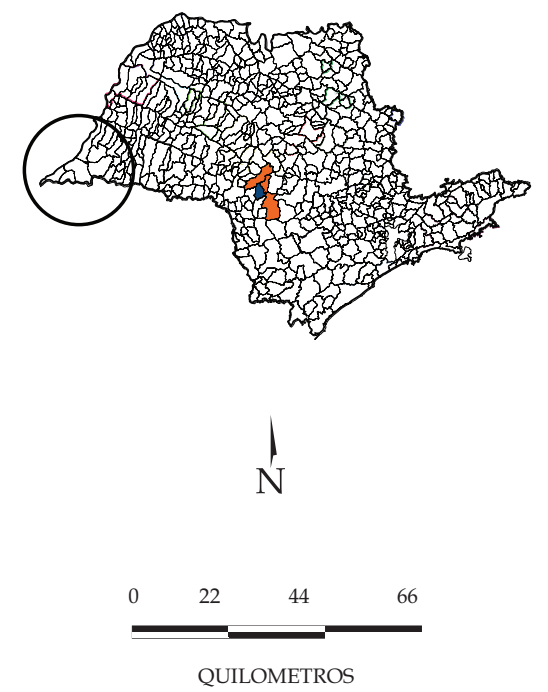

Fonte: elaboração própria 
Nessa região, a presença de assentamentos rurais estaduais teve início em 1980 com a mobilização de um contingente de sem-terra formado por barrageiros. A demanda por terra por parte desse grupo levou à implantação do assentamento Gleba XV de Novembro, a maior área de assentamento no Pontal do Paranapanema, localizada entre os municípios de Rosana e Euclides da Cunha Paulistas (vizinhos ao município de Teodoro Sampaio) (Ibid.).

Junto ao Pontal está a região de Andradina, que inclui Araçatuba, caracterizada pela forte presença dos assentamentos federais, também reconhecida pela atuação dos movimentos sociais e concentração de assentamentos rurais. Em 2003, no início da expansão da cana de açúcar, a região contava com doze assentamentos. Entre 2003 e 2010 foram criados outras 30 implantações gerando um acréscimo considerável de área parcelada (crescimento de 43\%) e de famílias beneficiadas (2.699). Apesar desse aumento maior do que em qualquer outra região do Estado ainda é evidente a força que a iniciativa pública disponibiliza ao agronegócio canavieiro.

Diferentemente do Pontal, as áreas em Andradina são terras públicas e devolutas, o Estado não paga por elas na desapropriação, apenas as benfeitorias. O que ocorre é uma ação diferente da desapropriação de propriedades privadas improdutivas. Simbólica na luta de terras em São Paulo, Andradina também conta com uma das implantações mais antigas como o assentamento Primavera. (FERRANTE, BARONE, et al., 2012).

A partir de 2003, uma nova condição se coloca para a organização dos projetos de assentamento rural. As associações estaduais de cooperativas agrícolas, responsáveis pela representação jurídica das instâncias estaduais do MST, passam a ser consideradas entidades prioritárias na contratação para elaboração dos Planos de Desenvolvimento de Assentamento - PDA -, item fundamental para viabilizar diferentes padrões de parcelamento 
e uso do solo de um projeto de assentamento, e etapa de planejamento, organização dos assentamentos e respectivos créditos. Previsto em âmbito nacional como uma das etapas para a criação do projeto de assentamento, o PDA deveria ter sido implementado a partir de convênios entre as entidades representativas e o INCRA, os dirigentes estaduais. Por isso, os diferentes estados registram experiências diferenciadas.

O desenvolvimento do plano propicia um envolvimento tanto por parte do poder público quanto do grupo que será assentado, evitando-se, assim, incongruências na construção do assentamento. A elaboração do PDA demanda uma equipe multidisciplinar para execução de cada etapa dos procedimentos que compõem esse método de projeto. Ainda que o PDA não tenha sido verificado nos assentamentos em São Paulo, identificaram-se formas de implantação que indicam a participação das famílias no desenho do projeto.

O parcelamento dos lotes no projeto de assentamento rural segue o formato dos loteamentos urbanos, diferenciados no tipo de uso da terra, infraestrutura disponibilizada e atividades desenvolvidas: o parcelamento parte da estrutura viária - existente ou proposta para a divisão dos lotes. Os assentamentos rurais são implantados em fazendas que podem ter sido áreas de produção extensiva ou hortos florestais, variáveis que podem interferir no processo de implantação e fixação das famílias que viverão da agricultura familiar. De outro lado, assim como num loteamento urbano, o traçado da área segue a lógica de lotes retangulares organizados ao longo de vias já existentes, articuladas com as vias propostas. São previstos, no projeto, outros usos para atender a legislação vigente, principalmente no que se refere à proteção de nascentes e corpos d'água. Esse tipo de parcelamento se reproduz nas diferentes regiões do estado, variando basicamente o tamanho do módulo que define o lote. 


\subsubsection{Projetos de Assentamento Federal - PA}

O INCRA é uma autarquia federal, atualmente subordinada ao Ministério de Desenvolvimento Agrário (MDA). Foi instituído em 197012, com a missão de realizar a reforma agrária, manter um cadastro nacional de imóveis rurais e administrar as terras públicas da União. O órgão é responsável pela implantação de assentamentos rurais tendo em vista o desenvolvimento regional. De acordo com as informações levantadas, os assentamentos do INCRA devem ser compatíveis com as características de cada região do país e devem estar de acordo com a legislação vigente, incluindo a ambiental - que é mais recente (1999). Por isso, a autarquia também é responsável por equacionar os passivos ambientais existentes dos assentamentos mais antigos.

Através das Superintendências Regionais (SR), o INCRA está presente em todos os estados do país. Em São Paulo, as ações são de responsabilidade da Superintendência Regional de São Paulo - SR08. Considerando que os assentamentos rurais são esparsos nas zonas rurais dos diferentes municípios e regiões do estado, e adotando uma política de caráter descentralizada, a SR08 alocou escritórios em alguns municípios estratégicos para atender as demandas e gerir a constituição dos assentamentos de forma mais próxima do campo. $\mathrm{O}$ estado de São Paulo conta - além dos escritórios regionais - com uma Unidade Avançada em Andradina, município da região do Pontal do Paranapanema, caracterizada pelos conflitos fundiários e com expressivo número de assentamentos.

A implantação de assentamentos rurais por parte do INCRA segue primeiramen- 
te as diretrizes do Estatuto da Terra ${ }^{13}$, o qual assegura o acesso à propriedade da terra, condicionada à sua função social, e visa promover e criar condições de acesso à terra por parte do trabalhador rural. Vale destacar que o artigo $4^{\circ}$ do Estatuto define, entre outros, as características do imóvel rural, o que é a propriedade familiar, o módulo rural, o minifúndio e o latifúndio. Uma das principais variantes de um projeto de assentamento é a área, porém outras também devem ser consideradas para a criação do projeto de assentamento: o levantamento socioeconômico da área; os tipos e as unidades de exploração econômica, perfeitamente determinados e caracterizados; quais as obras de infraestrutura e os órgãos de defesa econômica dos parceleiros necessários à implementação do projeto; o custo dos investimentos e a sua forma de aplicação; os serviços essenciais que deverão ser instalados no centro da comunidade; a renda familiar que se pretende alcançar; a colaboração a ser recebida dos órgãos públicos ou privados que celebrarem convênios ou acordos para a execução do projeto.

A lei prevê que a reforma agrária seja realizada a partir de planos periódicos nas diferentes escalas - nacional, estadual e municipal - e que sejam estabelecidos prazos e objetivos determinados. Isto, porém, não é o que se observa. Desde a definição da lei foram realizados apenas os dois Planos Nacionais de Reforma Agrária: o I PNRA de1985, que ficou distante das metas estabelecidas, e o II PNRA de 2003, que também estabeleceu metas que não foram cumpridas. Na escala estadual, o processo de arrecadação de terras devolutas diminuiu com o passar dos anos, pois a política de incentivo esteve voltada às produções de monocultura extensiva mecanizada ficando quase nula a política agrária no estado.

Nas duas instâncias, federal e estadual, as instituições responsáveis pela criação dos assentamentos passaram por processos de desmonte e, em alguns momentos, de retomada das equipes técnicas. Esses movimentos, gerados por mudanças de governo, prejudicaram
13 Lei $n^{\circ} 4.504$, de 30 de novembro de 1964 - regula os direitos e obrigações concernentes aos bens imóveis rurais, para os fins de execução da Reforma Agrária e promoção da Política Agrícola. 
a continuidade dos trabalhos realizados e refletiram diretamente na qualidade do ambiente construído dos assentamentos rurais. A implantação de assentamentos rurais por parte do INCRA está incluída no programa de reforma agrária, estabelecido em leis, decretos e normas de execução (NE), que definem critérios referentes ao acesso e à posse da terra.

O lote, em um assentamento federal, é adquirido através desse processo no qual o objetivo é viabilizar o acesso à propriedade da terra para os agricultores familiares. No âmbito federal, as leis que norteiam os princípios de base desse processo são: o Estatuto da Terra - Lei federal $n^{\circ}$ 4.505/1964 (BRASIL, 1964) - e a Lei Federal no 8.629/1993 (BRASIL, 1993), com regulamentações sobre os dispositivos constitucionais relativos à reforma agrária. Além do decreto $n^{\circ}$ 59.428/1966 (idem) que trata sobre colonização e outras formas de acesso à propriedade.

A área destinada à implantação de um assentamento pode ter origem em processos de desapropriação, compra/venda ou em área resultante de processo de discriminação, arrecadação e doação. O processo de assentamento do INCRA segue a orientação de instruções normativas - ou normas de execução (NE) -, que são instrumentos que regulamentam o trabalho dos técnicos para execução de suas ações. Na Tabela 4 são apresentadas as normas referentes à criação do projeto e à implantação de assentamentos.

A criação do assentamento é feita a partir da imissão de posse ${ }^{11}$ ao INCRA. O projeto parte do levantamento e do registro da área que será parcelada. Paralela ou anteriormente ao levantamento, é feita a seleção dos beneficiários. Após a identificação da área e dos estudos referentes à qualidade do solo, é feito o cálculo do módulo rural, o que permite definir a capacidade do assentamento e, consequentemente, o número de famílias que poderão ser assentadas. $\mathrm{O}$ desenho do projeto é desenvolvido por técnicos do INCRA. 11 Decisão judicial que confere a posse, nesse
caso da terra. 
Tabela 4: Instruções técnicas do INCRA para a criação e a implantação de projeto de assentamentos rural em São Paulo

\begin{tabular}{|l|l|l|}
\hline No. & Ano & Dispõe sobre: \\
\hline 34 & 1999 & Implantação de Projetos de Assentamento em terras obtidas pelo Programa de Reforma Agrária e dá outras providências. \\
\hline 41 & 2000 & $\begin{array}{l}\text { Fixa normas para a implementação do Programa Nacional de Reforma Agrária, abrangendo as ações de assentamento de } \\
\text { trabalhadores rurais e a atividade complementar de regularização fundiária. }\end{array}$ \\
\hline 15 & 2004 & Dispõe sobre o processo de implantação e desenvolvimento de projetos de assentamento de reforma agrária. \\
\hline 45 & 2005 & Dispõe sobre procedimentos para seleção de candidatos ao Programa Nacional de Reforma Agrária. \\
\hline 69 & 2008 & Dispõe sobre o processo de criação e o reconhecimento de projetos de assentamento de Reforma Agrária. \\
\hline
\end{tabular}

Fonte: elaborado pela autora

A provisão de infraestrutura básica está considerada nas referidas normativas, mas representam processo crítico da implantação do PA. Durante a fase de assentamento, os beneficiários contam com um primeiro aporte de recursos provenientes do Crédito Instalação, dividido em duas categorias: uma vai subsidiar ferramentas e insumos diversos; e a segunda para aquisição de material de construção. Nesse momento, as famílias também têm acesso ao crédito para iniciar a produção.

A elaboração do desenho do parcelamento para os projetos de assentamentos federais podem ser resumidos em seis etapas:

1) Liberação da área juridicamente - isso significa que o domínio e a posse estão em nome 


\section{do INCRA;}

2) Processo de criação do assentamento - é a abertura de um processo administrativo que cria institucionalmente o assentamento. A partir disso, é iniciado o processo de seleção;

3) Licenciamento ambiental - por ser um processo lento, é emitida pelo órgão responsável uma licença provisória (LP);

4) Mesa de seleção - é uma pré-seleção e esses beneficiários devem passar por entrevistas sobre as perspectivas da vida no assentamento. São verificados, principalmente, objetivos de produção e características da família/perfil;

5) Projeto do assentamento - nesse momento, com o levantamento topográfico da área em mãos e o resultado das análises da qualidade do solo, os técnicos traçam as vias e desenham os lotes a partir das condições e benfeitorias existentes. Também nesse momento devem ser observadas as leis ambientais, principalmente no que diz respeito à preservação dos recursos naturais;

6) Implantação - definição de infraestrutura necessária: distribuição de água, saneamento/fossas, definição de uso do solo.

Em São Paulo, a partir do momento em que a área está liberada judicialmente, as etapas de licenciamento ambiental (3), mesa de seleção (4) e mesmo a implantação (6) não têm sido cumpridas na sua totalidade. Muitas vezes os beneficiários selecionados já estão na terra ou o fazem mediante a liberação judicial. A partir da elaboração do projeto (5), os lotes são divididos, distribuídos e passam a ser habitados pelas famílias que, inicialmente, remontam o barraco de lona usado no período de acampamento. A demarcação com cercas 
e o início do tratamento da terra para a produção são as primeiras ações no lote, assim como o acesso aos créditos e financiamentos específicos conforme o anexo da NE 34/1999 - instrumento de liberação de crédito.

Por meio da NE 45/2005 (INCRA), o INCRA estabelece os procedimentos técnicos e administrativos para a seleção de beneficiários do Programa Nacional de Reforma Agrária. Esse processo seletivo de caráter nacional é feito em duas etapas: a da organização para o assentamento e a da homologação do assentado. Quando existe algum lote vago, a seleção ocorre da mesma maneira. Os critérios adotados para o processo de seleção e classificação das famílias segue os parâmetros do tamanho da família (TF); força de trabalho da família (FT); idade do candidato (IC); tempo de atividade agrícola (TAA); moradia no imóvel (MI); moradia no município (MM); tempo de residência no imóvel (TR); e a renda anual da família (RAF).

O processo de inscrição, tem como objetivo identificar e dimensionar a demanda por assentamentos, mas não está organizado de forma que viabilize a participação dos beneficiários. Levantando informações sobre a prática em campo, entre o projeto e a implantação, é possível perceber que a participação dos beneficiários é rara; depende muito da organização social do grupo e da relação estabelecida entre o grupo e o técnico de campo, responsável por trazer as informações para a produção dos projetos.

A etapa de homologação tem como resultante uma Relação de Beneficiários (RB), emitida após aprovação do superintendente regional. Depois disso, o beneficiário e cônjuge, quando o caso, assina o Termo de Compromisso, válido até a assinatura do instrumento definitivo - é esse instrumento que comprova o término do contrato de concessão de uso tornando o assentado o proprietário daquele lote. Destacamos, do capítulo II da referida 
NE, os artigos 13, 14 e 15 que definem os procedimentos para o projeto do assentamento:

Art. 13. O assentamento será realizado respeitando-se as formas de organização social pré-existentes, sobretudo quando se tratar de áreas já povoadas, ouvindo os interessados.

Art. 14. O beneficiário (a) deve participar das discussões quanto a seus direitos e deveres, devendo ser incentivado a interagir com os demais membros do assentamento.

Art. 15. O candidato (a) selecionado, homologado como beneficiário(a) do Programa Nacional de Reforma Agrária que por qualquer motivo desistir do assentamento nesta fase e não tenha assinado o instrumento definitivo, nem recebido Crédito Instalação, deve assinar Termo de Desistência, evitando tornar-se um ex-beneficiário da reforma agrária, condição impeditiva à sua participação em outros processos seletivos para o mesmo fim. (BRASIL,

2005a)

Os instrumentos disponibilizados para elaboração do projeto de assentamento federal não fazem referência a um programa de necessidades específico que determine tipos de uso para áreas, de acordo com as especificidades de cada grupo; tampouco é abordada a temática do desenho para o projeto de assentamento. Não há um estudo sobre a relação entre a forma da implantação e as condições do habitat constituído com a implantação do assentamento. São raros os projetos de assentamento que assumem uma forma de parcelamento diferenciada e que tenham como objetivo atender as diferentes escalas das práticas cotidianas.

Os assentamentos resultantes do tipo PA têm previsão de obter a titulação da terra em nome do beneficiário. Esse processo ocorre após a emancipação do assentamento, quando o beneficiário começa a pagar, com um prazo de vinte anos, referente à aquisição daquela parcela de terra e dos investimentos realizados. Segundo as informações levantadas na pesquisa realizada no INCRA, desta vez na divisão do fundiário, a definição da forma de divisão dos lotes é resultante de parâmetros técnicos e demanda social, sendo que cada 
assentamento tem um grau de pressão diferente do outro. Em seu relato, durante o levantamento de campo em 2013, o chefe da divisão de assuntos fundiários do INCRA afirma que "às vezes a técnica fica comprometida para atender a demanda social". A demanda a que se refere é à forma de dividir os lotes, segundo ele, as famílias têm preferência "pela lógica da divisão de propriedade privada". A mudança na forma de ocupar o espaço interfere nas dinâmicas do grupo uma vez que a união das famílias na fase anterior, no acampamento, é desfeita a partir do momento que as famílias ocupam o lote individual.

A pressão do mercado de terras, fortalecido com os programas e com as políticas de financiamento habitacional, acabaram por aumentar o valor da terra. Em São Paulo, o problema da terra valorizada, somado ao fato de o INCRA restringir o custo para desapropriação para assentamento, faz com que o valor não seja superior à R\$ 100 mil reais, dificultando a criação dos assentamentos. Alterando as condições para criar um assentamento, com número significativo de lotes, de forma atender a demanda por terra, em alguns casos, é preciso diminuir o tamanho do lote, economizar na aquisição da terra para gastar mais no desenvolvimento e manutenção da família no lote.

Tendo em vista a problemática diagnosticada e a perspectiva de melhorar a evasão e venda de lotes dos assentamentos, a adoção de um tipo de assentamento ambientalmente diferenciado, como o Projeto de Desenvolvimento Sustentável - PDS, surgiu em São Paulo como alternativa para assegurar o envolvimento coletivo. $O$ fato de não haver titulação da terra, esse tipo de projeto vem demonstrar maior liberdade para o desenho de implantação. É como se fugisse da lógica da divisão de propriedade que segue padrão de divisão ortogonal.

Durante a pesquisa, foi feito levantamento no setor de cartografia para verificar as 
resultantes da aplicação das normativas e das demandas expressas em mapas. Foi possível identificar diferentes traçados - que organizam os lotes e as outras áreas - nos desenhos de implantação, que podem representar conceitos de parcelamentos diferenciados e que expressam uma possível preocupação com a relação do espaço com as escalas do cotidiano.

\subsubsection{Projeto de Desenvolvimento Sustentável - PDS}

A principal diferença entre o PA e o PDS. Este é um tipo de projeto que estabelece normas para o uso do solo e demais recursos naturais, bem como regulamenta o uso de insumos externos e poluentes, como agrotóxicos. Nesse sentido, as normas estimulam a prática de uma agricultura ecológica; no entanto, não se verificam orientações técnicas e créditos diferenciados (FERRANTE, BARONE et al., 2012).

Criado para o desenvolvimento de atividades ambientalmente diferenciadas, esse tipo de projeto foi destinado às populações que baseiam sua subsistência no extrativismo, na agricultura familiar ou em outras atividades de baixo impacto ambiental. Previsto inicialmente para ser implantado na região da Amazônia, em São Paulo, alguns casos podem ser verificados próximos às regiões metropolitanas. Além disso, o desenho do parcelamento parte da espacialização da legislação ambiental vigente, diferentemente dos outros projetos. Assim, como na tipologia PA, o PDS é criado pela União seguindo os procedimentos iniciais de obtenção e identificação da área. É uma tipologia recente, criada a partir de 1999, definida pela NE 93/2010 (INCRA) que dispõe sobre os modelos de contrato de concessão de direito real de uso para os projetos de assentamento diferenciados ambientalmente no qual 
está inserido o PDS.

Esse tipo de assentamento não dota o beneficiário de um título de domínio, mas concede o direito real de uso mediante titulação, que tem valor igual ao de outro tipo de assentamento. $\mathrm{O}$ acesso aos créditos e financiamentos está previsto para ocorrer da mesma maneira que nos assentamentos do tipo PA, assim como a provisão de infraestrutura básica. A elaboração desse tipo de projeto considera a manutenção do meio físico existente como premissa, não permite derrubar a mata existente e as parcelas devem ser adequadas às áreas disponíveis. Para isso, os lotes são menores, de aproximadamente 1 hectare (em São Paulo, a parcela dos assentamentos tipo PA variam em torno de 12ha a 16ha).

O número de famílias que podem ser assentadas é adequado à capacidade de cada PDS, que varia conforme área disponível, considerada descoberta, mantendo preservada toda área com vegetação existente. Os procedimentos para elaboração desse projeto fazem referência a um cadastro de áreas úteis, abertas e identificadas a partir de recursos como mapa, foto aérea e GPS. O traçado das vias existentes e as áreas cobertas por vegetação determinam a organização dos lotes e orientam a produção, predominantemente de produtos de horticultura e fruticultura, embora exista criação de pequeno porte (aves e suínos), voltados ao autoconsumo do que para comercialização. A figura 4 ilustra o projeto de desenvolvimento sustentável Fazenda da Barra, do tipo agroecológico, está localizado no município de Ribeirão Preto, noroeste de São Paulo. 


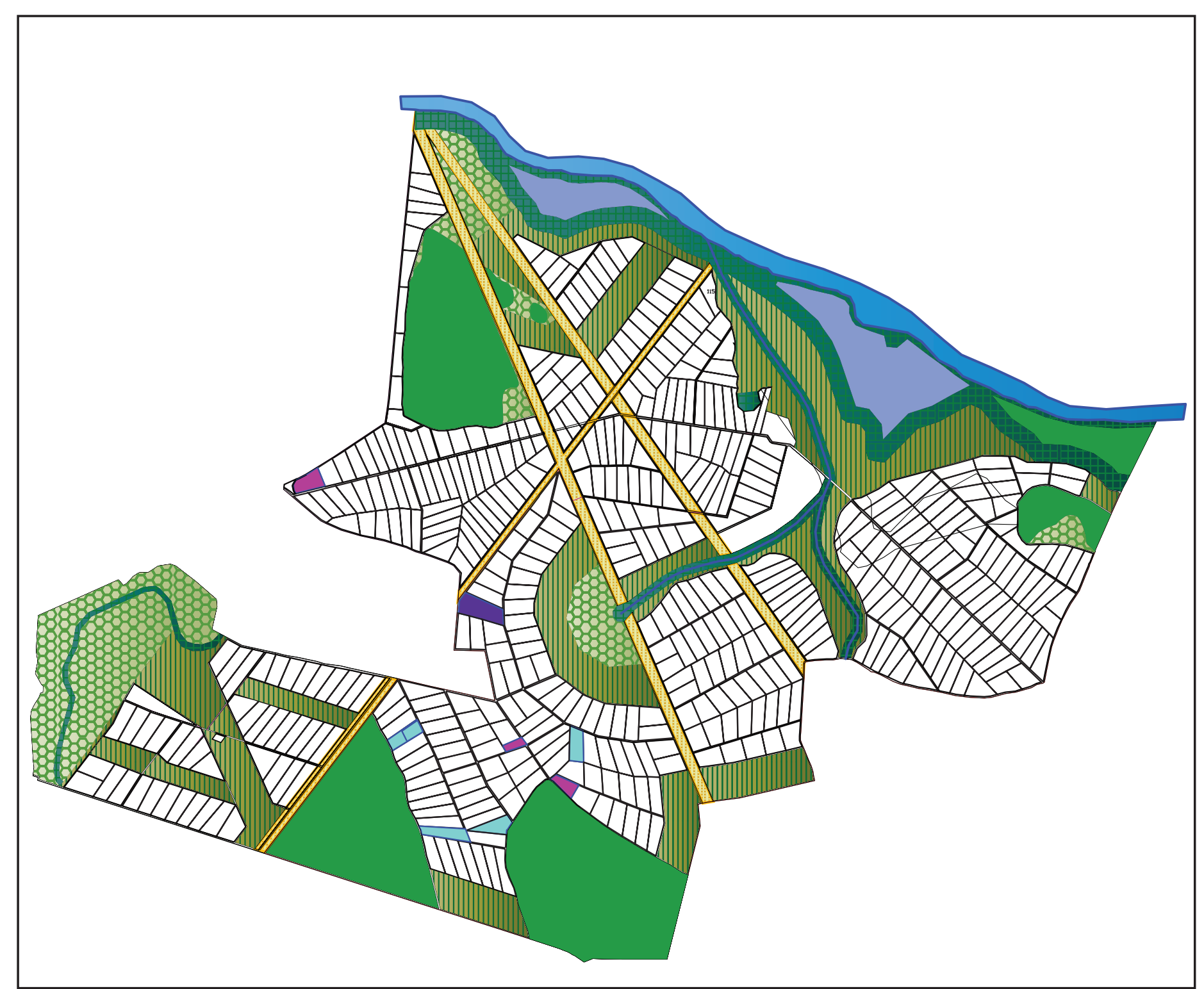

Figura 4: PDS Fazenda da Barra.

\section{Legenda}

Área Comercial

Área Coletiva

Área Coleti/Comercial

BA Reservas Legais a serem Recuperadas

||l||l| Reservas Legais - SAFs

Reservas Existentes

APP

Várzea

$\square$ Rios e córregos

․:-1:|| Linhões

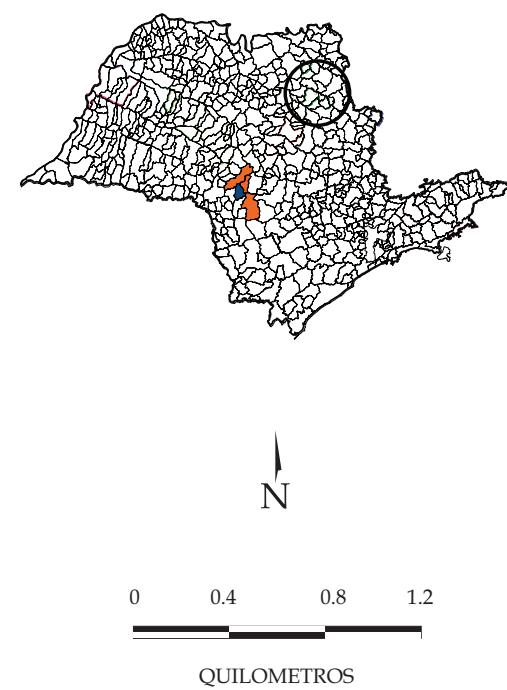

Fonte: INCRA 


\subsubsection{Projeto de Assentamento Estadual - PE}

No âmbito estadual, os assentamentos rurais e as atividades vinculadas à temática dos assentamentos rurais são parte da responsabilidade da atual Fundação Instituo de Terras do Estado de São Paulo - ITESP. A Fundação ITESP “José Gomes da Silva” foi regulamentada pelo Decreto 44.294/99 (ITESP) e finaliza a sequência de mudanças sofridas pelos órgãos estaduais ligados às questões agrária e fundiária do Estado.

Em parceria com a Secretaria de Estado da Justiça e da Defesa da Cidadania, a Fundação ITESP é responsável por planejar e executar as políticas agrária e fundiária no âmbito do Estado de São Paulo. Atua na implantação de assentamentos rurais, desde a criação até a implantação, a provisão de infraestrutura - como abertura de estradas, furação de poços - e outras políticas públicas que buscam o desenvolvimento e a fixação dessas comunidades. A prestação de serviço em assistência técnica às famílias nos assentamentos rurais é a principal atividade desenvolvida na Fundação.

Atuando de forma descentralizada, principalmente pela dispersão dos assentamentos, o ITESP está representado em 7 regionais, localizadas em municípios onde há assentamento estadual, dando suporte ao trabalho desenvolvido pelas cinco diretorias locadas na sede em São Paulo. Cada diretoria conta com assistência técnica, apoio administrativo, grupos de trabalho de campo e duas ou três gerências que estão divididas em grupos mais específicos. A Regularização fundiária de áreas urbanas ou rurais está incluída na temática político-jurídico das atividades desenvolvidas pelo Instituto de Terras. As ações estão localizadas em 82 municípios, e ocorreram nos últimos 23 anos através do Programa Minha Terra que, em parceria com prefeituras e com a Procuradoria Geral do Estado, concedeu títulos de 
domínio às famílias.

A origem do ITESP está vinculada à execução da Lei de Revisão agrária, instituída no governo de Carvalho Pinto, iniciado em 1960. O modelo do loteamento contrastava com a paisagem da pequena propriedade rural paulista. Dizendo antecipar as demandas por reforma agrária que já agitavam o país, principalmente no nordeste, a Revisão coibiria a permanência de terras improdutivas no Estado de São Paulo com a cobrança de altos impostos. Paralelo a isso, o acesso dos trabalhadores rurais às pequenas propriedades seriam facilitados através dos assentamentos rurais em terras desapropriadas. A intenção era seguir o padrão americano de pequenas propriedades rurais em áreas munidas de infraestrutura de produção, repassada a baixo custo e com longo prazo de pagamento. Era uma forma de idealizar uma classe média rural que, além de produzir, consumiria os produtos oriundos do assentamento.

Com o início da democratização, em 1985, foram promulgadas duas leis estaduais relevantes para a política agrária no estado de São Paulo. Dispondo sobre as atividades relacionadas ao meio rural as leis 4.925/85 e 4.957/85 (SÃO PAULO, 1985 a; 1985b), sobre o aproveitamento e valorização dos recursos fundiários do estado e sua destinação para a reforma agrária, incluindo o assentamento de trabalhadores rurais, retoma a iniciativa estadual paulista de criar assentamentos rurais.

Os procedimentos do ITESP para a implantação dos assentamentos rurais e os elementos que constituem a política agrária paulista foram organizados em uma publicação de dez volumes, lançados em 1998, chamadas de Cadernos ITESP, estão listadas no quadro 3.

Nos cadernos estão contidas as diretrizes que devem ser consideradas para a elaboração de um projeto de assentamento estadual entre outras informações relevantes ao 
desenvolvimento agrário do estado. O projeto físico do assentamento se constrói em áreas de domínio público estadual, são terras públicas, áreas arrecadadas em ações reivindicatórias, áreas obtidas por desapropriação ou aquisição federal. O objetivo da publicação foi estabelecer bases técnicas e diretrizes econômicas que pudessem orientar a subsistência e o desenvolvimento dos trabalhadores rurais, através do acesso à terra, meios de produção e habitação.

O caderno 5 descreve o caminho técnico seguido para conhecer a estrutura fundiária de determinada região. A definição dominial é o maior problema enfrentado nos trabalhos de regularização de uso e posse da terra em grandes extensões territoriais. É por isso que são realizados os levantamentos, seguindo parâmetros fundiários que delimitam as divisas e reconhecem os ocupantes da gleba.

Para o projeto de implantação do projeto de assentamento, o ITESP elabora o planejamento territorial considerando critérios agronômicos, socioeconômicos e ambientais, além daqueles que definem o planejamento territorial e o cálculo do módulo para os assentamentos. Os critérios são aplicados sobre os dados resultantes do levantamento cadastral, gerando a planta do projeto para o parcelamento da área. São usados de forma integrada instrumentos como o GPS (Global Position System), topografia convencional e restituição de aerofotogramétrica digital da altimetria. Esse caderno apresenta o assentamento como o projeto de um novo bairro rural, de uma nova comunidade na qual os trabalhadores rurais sem-terra tornam-se agricultores familiares e contribuem para o desenvolvimento regional; por isso, devem ter condições para que as famílias sobrevivam e se desenvolvam em uma nova comunidade.

O caderno 8 apresenta a metodologia que o ITESP desenvolveu para o planejamento 
territorial dos assentamentos rurais. São diretrizes estabelecidas para o trabalho da assistência técnica e da extensão rural que devem considerar a participação da comunidade. A parte inicial são os levantamentos e estudos do meio físico, além da determinação dos parâmetros socioeconômicos que são discutidos com o grupo de famílias selecionado. Nesse momento, os técnicos informam que serão preservadas e recuperadas áreas de reservas florestais e matas ciliares; as estradas serão traçadas para que tenham inclinação suave e integradas no planejamento conservacionista dos solos, serão previstas áreas de vilas, equipamentos sociais e lazer de acordo com as necessidades da população moradora.

Quadro 3 : Cadernos que regulamentam a criação e implantação de PE

\begin{tabular}{|c|c|}
\hline 1 & $\begin{array}{l}\text { Retratos da terra: Perfil socioeconômico dos Assentamentos do Estado de São } \\
\text { Paulo - 96/97 }\end{array}$ \\
\hline 2 & $\begin{array}{l}\text { Pontal Verde - Plano de recuperação ambiental nos assentamentos do Pontal do } \\
\text { Paranapanema. }\end{array}$ \\
\hline 3 & Negros no Ribeira - Reconhecimento étnico e conquista do território \\
\hline 4 & $\begin{array}{l}\text { Terra e Cidadãos - Aspectos da ação de regularização fundiária no Estado de São } \\
\text { Paulo. }\end{array}$ \\
\hline 5 & $\begin{array}{l}\text { Técnicas e Rumos - Sistemática aplicada ao cadastro técnico rural e demarcação } \\
\text { de assentamentos. }\end{array}$ \\
\hline 6 & Mediação no Campo - Estratégias de ação em situações de conflito. \\
\hline 7 & Cultivando Sonhos - Caminhos para a assistência técnica na reforma agrária. \\
\hline 8 & $\begin{array}{l}\text { Sítios e Situantes - Planejamento Territorial e cálculo de módulo para } \\
\text { assentamentos rurais. }\end{array}$ \\
\hline 9 & $\begin{array}{l}\text { Retrato da Terra 97/98 - Perfil socioeconômico e balanço da produção } \\
\text { agropecuária dos assentamentos rurais do Estado de São Paulo. }\end{array}$ \\
\hline 10 & $\begin{array}{l}\text { Construindo o Futuro - Política de investimento em assentamentos rurais, seus } \\
\text { custos e resultados. }\end{array}$ \\
\hline
\end{tabular}

Fonte: ITESP, 2012 
Esse caderno também define que o planejamento territorial nos projetos de assentamentos de trabalhadores é o planejamento físico e a organização espacial das áreas de terras. Faz referencia ao tema da organização espacial rural, que é pouco explorado e que não existe material normativo atualizado sobre o planejamento físico de terras destinadas para os assentamentos rurais, o que justifica a proposta da pesquisa em andamento. $\mathrm{O}$ caderno propõe, ainda, a adoção do termo 'sítio' para fazer referência ao lote ou parcela de assentamento, e reconhece o desafio de se desenvolver uma metodologia que possa estabelecer parâmetros que considerem as particularidades sociais, técnicas e políticas de um projeto de assentamento. O documento cita fatores que devem ser considerados como, por exemplo, o número médio de trabalhadores por família (força de trabalho), potencial do solo, mercados. Entre outros passos, alguns são decididos por parâmetros técnicos e outros de forma participativa com os assentados.

Para o planejamento participativo, o caderno 5 apresenta os temas que devem ser discutidos com a comunidade assentada, como por exemplo, o histórico da reforma agrária, as experiências, as culturas, os limites de renda e a necessidade ambiental. Também trata da intenção de moradia nos sítios ou em agrovila, a infraestrutura necessária e o núcleo de serviços, os sistemas de produção entre outras devem ser considerados.

O parcelamento da área é a última etapa do projeto de assentamento, realizado a partir de um mapa no qual os sítios estão distribuídos e organizados por estradas projetadas, núcleo de serviços, área de moradia e áreas de preservação ou regeneração ambiental. Nas diretrizes propostas, é feita uma aproximação acerca da questão habitacional. Para isso, o caderno define que a área da moradia compreende a localização da habitação, o sistema de organização da produção e os hábitos da população assentada. Faz referência à definição dos espaços, a partir da sugestão para organizar os sistemas de maneira coletivo e/ ou mis- 
to, indicando que as moradias estejam agrupadas em bairro agrícola ou agrovila.

Quando adotado o sistema de produção familiar individual, a localização da moradia no lote é indiferente. Por fim, o caderno define que Agrovila é o aglomerado de habitações e infraestrutura implantada em área pequena com características urbanas... e bairro agrícola é um agrupamento de moradias em sítios familiares, no sítio apenas a habitação organizada a partir do núcleo de serviço.

\subsection{Arquitetura dos assentamentos: implantação e parcelamento}

Ainda que não seja reconhecida institucionalmente, a implantação de um assentamento rural pode ser identificada pela forma do parcelamento. Analisando o desenho dos assentamentos implantados em São Paulo, é possível interpretar o parcelamento a partir da forma de sua organização. Como visto, os assentamentos podem ser parcelados para projetos de vida individuais ou coletivos. Nos modos individuais, a família tem direito a um lote. No quadro 4 as opções de parcelamento foram organizadas, pois serão tomados como variáveis para estudar as diferentes diretrizes de projeto.

Partindo do entendimento de que em São Paulo existem três programas de projetos para a implantação de assentamentos rural - sendo dois deles criados em âmbito federal e

o outro criado por meio de ações estaduais - as diretrizes resultam em parcelamentos que podem ser diferenciados e caracterizados como padrões de implantação. A aplicação desses conceitos permite identificar o tipo de projeto a partir da leitura de seu traçado, o qual defi- 
ne a forma do projeto e também indica a opção de habitat pretendida.

Em São Paulo, a pesquisa revelou que 96,94\% dos assentamentos rurais implantados no Estado são do tipo xadrez ou espinha de peixe. Por isso, toma-se essa forma de implantação como objeto para a pesquisa. As formas menos incidentes foram descartadas, pois aparecem como experiências isoladas.

\subsubsection{Xadrez - espinha de peixe}

O desenho da maioria das implantações assemelha-se a um tabuleiro de xadrez: parcelas retangulares, semelhantes, organizadas por arruamento existente e/ou proposto. Em alguns casos, a forma assemelha-se a uma espinha de peixe. Nesse assentamento o lote é individual, dividido entre a moradia e a produção organizados pelo traçado das vias ${ }^{15}$.

A localização da casa implantada no lote desse tipo de assentamento implica em distância relevante para o percurso a pé. Ainda que a área, as benfeitorias e as características ambientais de cada fazenda sejam variáveis, faz-se necessário um diagnóstico de cada caso para o desenho do futuro loteamento. Diferentemente do que acontece no ambiente urbano, as características de cada lote em um assentamento rural podem variar de acordo com a presença de água, pedras, terras boa ou ruim, morro, baixada, estradas, sedes ou equipamentos de transformação de insumos agrícolas

Os lotes dos assentamentos no estado de São Paulo têm em média de 10 a 12 hectares. As distâncias a serem percorridas compreendem a escala do automóvel. A escala do
Quadro 4: Opção de parcelamento

\begin{tabular}{|l|l|}
\hline $\begin{array}{l}\text { Lote individual para } \\
\text { produção e moradia }\end{array}$ & Xadrez/Raio \\
\hline $\begin{array}{l}\text { Lote individual para mo- } \\
\text { radia separado de um lote } \\
\text { de produção }\end{array}$ & Agrovila \\
\hline $\begin{array}{l}\text { Lote individual para mo- } \\
\text { radia e produção coletiva }\end{array}$ & PDS \\
\hline
\end{tabular} Fonte: elaboração própria com base em le-
vantamento de campo, 2013.

Quadro 5: Forma de implantação dos assentamentos

\begin{tabular}{|l|c|l|}
\hline $\begin{array}{l}\text { Xadrez/Espinha de } \\
\text { Peixe }\end{array}$ & 159 & $\mathbf{9 6 , 9 4 \%}$ \\
\hline Agrovila & 3 & $\mathbf{1 , 8 3} \%$ \\
\hline $\begin{array}{l}\text { Roda de Carroça/Raio } \\
\text { de Sol }\end{array}$ & 3 & $\mathbf{1 , 2 2} \%$ \\
\hline Total & 164 & $\mathbf{1 0 0} \%$ \\
\hline
\end{tabular}

Fonte: elaboração própria com base em levantamento de campo, 2013.

15 No assentamento rural as vias consideradas de acesso/principal tem $12 \mathrm{~m}$ de largura e as vias secundária/de acesso ao lote $8 \mathrm{~m}$. 
pedestre fica comprometida na dimensão do assentamento. A distância entre as moradias, resultante dessa forma de ocupação não só diminui a convivência das pessoas refletindo na organização social do grupo de famílias, como também dificulta o acompanhamento dos programas de provisão via política pública. A forma dispersa de organizar a moradia no lote, e a distância entre cada uma, encarece a provisão de infraestrutura como água, luz e estradas. Dependendo do tamanho da fazenda, às vezes é necessário dividir a área destinada ao uso coletivo em outras menores distribuídas no interior do assentamento.

Localizado na região central do Estado, o Horto Aimorés é um exemplo de assentamento federal (PA), seu parcelamento é do tipoxadrez/espinha de peixe. Há um parcelamento diferenciado ao longo da linha de alta tensão; são lotes menores, do tipo: pararural (1). Em verde, as áreas de reserva legal e área de preservação permanente várzea/ preservação nas margens dos córregos e rios. 


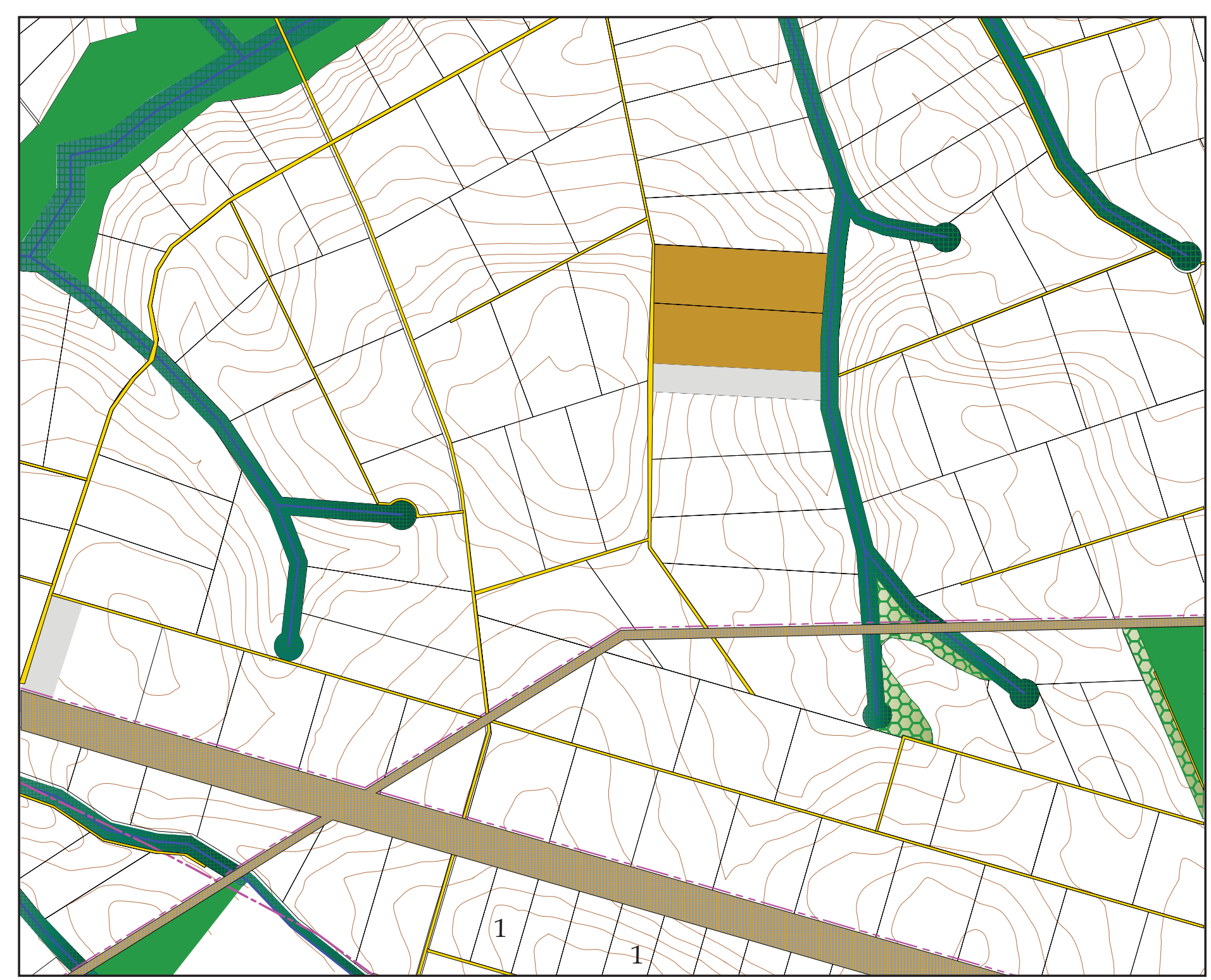

Figura 5: Projeto de Assentamento - PA Horto Aimorés: xadrez/espinha.
Legenda

- Vias

- Curva de nível

- Divisa de lotes

ED Reservas Legais a serem

Recuperadas

Reservas Existentes

APP

- Rios e córegos

Rede de Alta Tenção

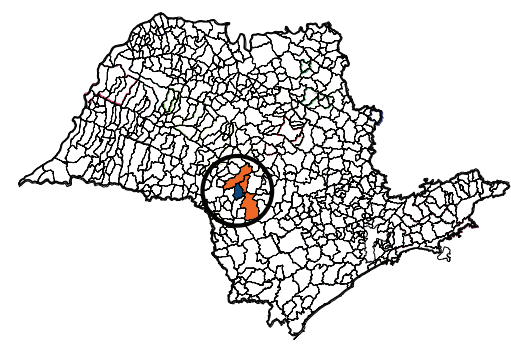

N

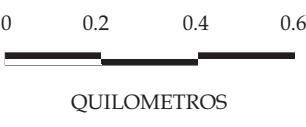

Fonte: INCRA 


\subsubsection{Agrovila}

Outras formas de parcelamento do assentamento, que aparecem com menor frequência, resultam de projeto elaborado com a participação dos futuros moradores. Algumas são resultantes de um processo de projeto mais cuidadoso, com a participação dos futuros moradores, resultando em formas diferenciadas, identificadas com conceitos de uso e ocupação diferentes do tradicional lote individual. Essa diferenciação pode ser identificada pelo traçado do projeto de implantação.

Semelhante ao xadrez, por ter traçado ortogonal, o assentamento em forma de agrovila foi um dos primeiros implantados em terras de domínio estadual. Nesse tipo, a área é dividida em lotes de produção e lotes de moradia, proporcionando a proximidade das casas facilitando a provisão de infraestrutura. Tal aproximação e a adjacência das áreas de uso comum facilitam o convívio das famílias, a comunicação e o transporte. Essa forma de implantação pode gerar melhor dinâmica na operacionalização de políticas públicas.

É possível observar, o assentamento Sumaré (Figura 6) , localizado na Região Metropolitana de Campinas - RMC, nele, pelo menos duas fases de implantação podem ser identificadas pela lógica do traçado. O Sumaré 1 foi projetado a partir de lotes individuais organizados ao redor de uma área de uso comunitário. Os lotes são individuais e destinados à moradia e à produção.

O Sumaré 2, formado por quatro áreas - denominadas glebas A, B, C e D. Cada uma foi parcelada de um jeito. A gleba A tem lotes do tipo pararrual, organizados como uma agrovila. Na gleba D é possível identificar que há lotes pequenos e lotes maiores, indicando 
a opção próxima ao modelo de agrovila: lotes individuais de moradia estão organizados ao longo de uma via, próximos entre si, e lotes individuais de produção. As áreas correspondentes à gleba E e a área do Sumaré I estão separadas por uma área desapropriada pela Prefeitura Municipal de Sumaré em 1986.

No quadro 6 apresentam-se as variáveis deste projeto e que definem as características do projeto. Na figura 6 o projeto do parcelamento com a indicação das glebas, áreas de preservação e a divisão dos lotes.
Quadro 6: Variáveis do PE Sumaré

\begin{tabular}{|l|l|l|}
\hline \multicolumn{3}{|c|}{ Assentamento Sumaré } \\
\hline Minicípio & \multicolumn{2}{|c|}{ Sumaré } \\
\hline Estadual & \multicolumn{2}{|c|}{ ITESP } \\
\hline Data: & Nov. & 2009 \\
\hline $\begin{array}{l}\text { Área desapropriada } \\
\text { pela prefeitura munici- } \\
\text { pal de Sumaré: decreto } \\
\text { n. 3656 }\end{array}$ & Jun. & 1986 \\
\hline \multicolumn{3}{|c|}{ QUADRO DE ÁREAS } \\
\hline uso projetado & área (ha) & $\%$ \\
\hline Área Agrícola & 428.2431 & 73,08 \\
\hline Estradas & 14.7166 & 2,52 \\
\hline $\begin{array}{l}\text { Reseva Florestal + APP } \\
\text { + Brejo }\end{array}$ & 120.380 & 21,13 \\
\hline Área Comunitária & 11.4988 & 1,97 \\
\hline área Ocupada & 7.5810 & 1,30 \\
\hline $\begin{array}{l}\text { Área total do Assenta- } \\
\text { mento }\end{array}$ & 582.4198 & 100 \\
\hline
\end{tabular}

Fonte: Elaborado pela autora a partir do levantamento de campo 2013. 


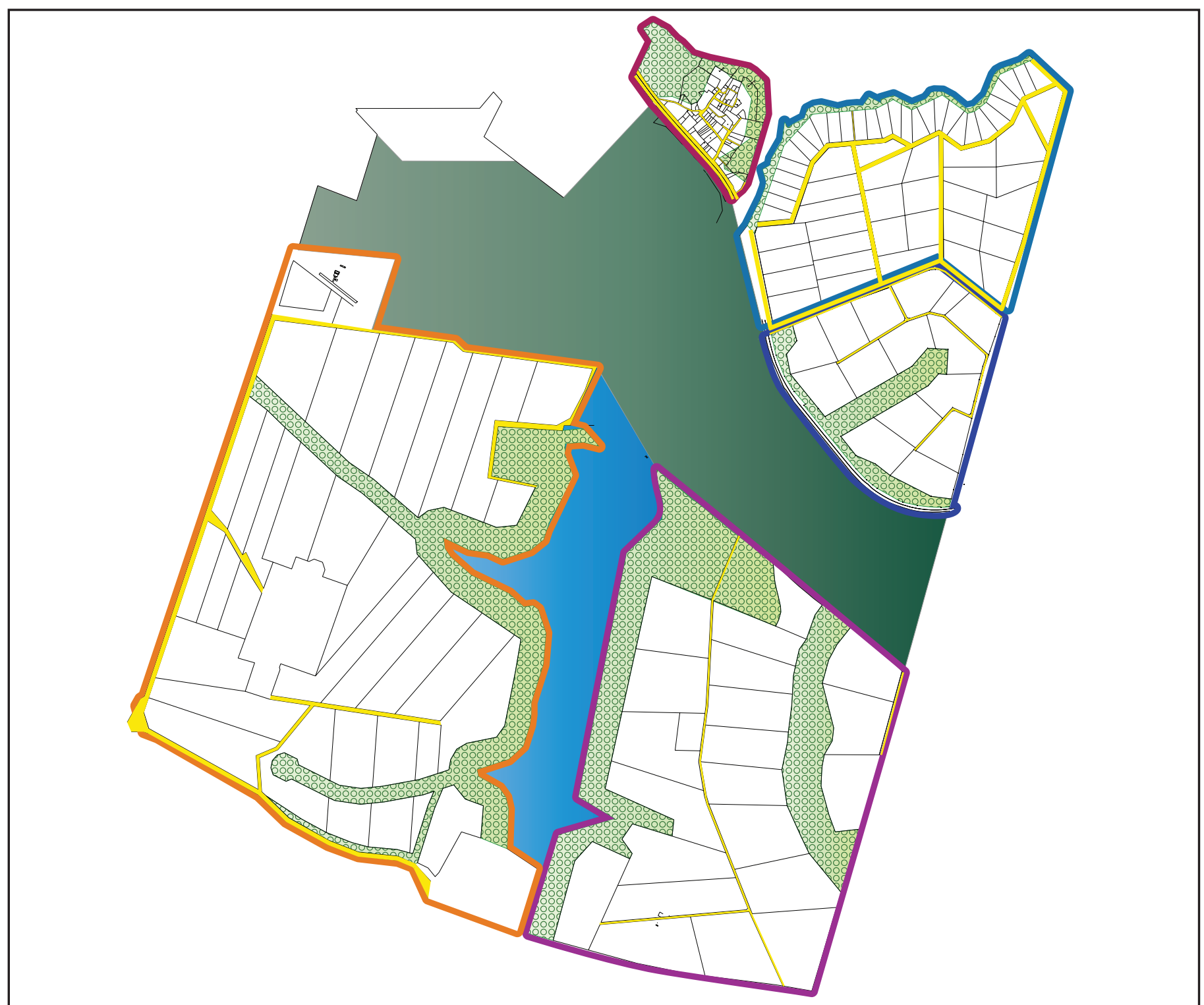

Legenda

- Perimetro Sumaré 1 Sumaré 2:

- Perimetro Gleba A

- Perimetro Gleba B

- Perimetro Gleba C

— Perimetro Gleba D

- Vias

- Área desapropriada pela PM Sumaré.

○ัoŏ Área de preservação Permanente

- Reservatório córrego Hortolândia

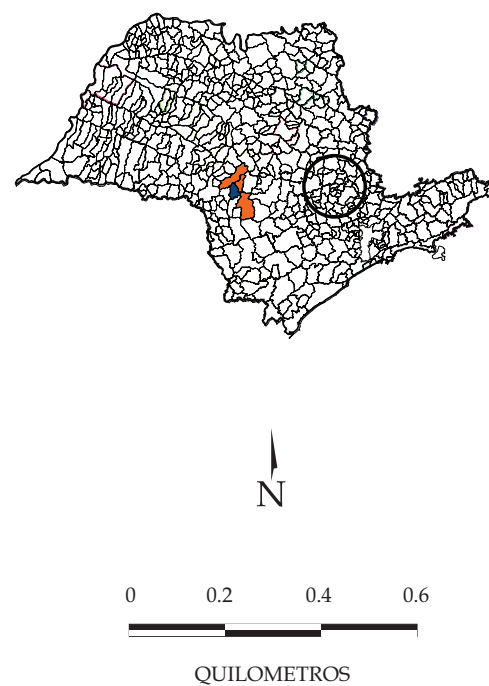

Figura 6: Projeto Estadual - PE Sumaré: agrovila 


\subsubsection{Roda De Carroça}

O assentamento implantado na forma de 'roda de carroça' também é conhecido como Raio de Sol. Essa forma de desenhar o projeto considera a implantação da casa no lote. $\mathrm{O}$ traçado parte do princípio de que as casas devem estar próximas e organizadas em torno de uma área de uso coletivo. Essa área comum tem forma de círculo e organiza os lotes de forma radial. As divisões dos lotes parecem aros de uma roda de carroça. A construção das moradias é próxima ao acesso do lote e são próximas entre si. Assim como a agrovila, esse tipo de assentamento/ou de traçado favorece o convívio social, o transporte e a implantação de rede de infraestrutura. Essa forma é mais adequada para fazendas com áreas com pouca declividade.

Como exemplo, o assentamento Padre Josimo construído na região do Pontal do Paranapanema, foi implantado em 2003, data que coincide com o ano em que o MST torna-se apto $^{13}$ a elaborar o PDA do assentamento. Esse traçado é característico de ações participativas, nas quais o projeto do assentamento vincula-se ao projeto de vida que se pretende constituir no lugar. Localizado em Teodoro Sampaio, município da região do pontal do Paranapanema, o domínio da terra é estadual e está organizado em 96 lotes, distribuídos numa área total de 2290,19ha. Pode-se verificar, por meio do mapa (Figura 7), ao menos quatro áreas comunitárias, sendo que cada uma forma o centro de uma roda. Os lotes em forma radial formam um aro. O verde indica a área de reserva florestal. No entorno externo à área verde, os vizinhos do assentamento são áreas da CESP - Companhia Energética de São Paulo. a vizinhança são as terras do assentamento Santa Cruz da Alcidia (implantado em 2000) em terras estaduais.
Quadro 7: Variáveis do PE Padre Josimo

\begin{tabular}{|l|l|l|}
\hline \multicolumn{1}{|c|}{ Assentamento Padre Josimo (96 Lotes) } \\
\hline Minicípio & \multicolumn{2}{|c|}{$\begin{array}{c}\text { Teodoro Sam- } \\
\text { paio }\end{array}$} \\
\hline Estadual & \multicolumn{2}{|c|}{ ITESP } \\
\hline Data: & Abril & 2004 \\
\hline \multicolumn{3}{|c|}{ QUADRO DE ÁREAS } \\
\hline uso projetado & $\begin{array}{l}\text { área } \\
\text { (ha) }\end{array}$ & $\%$ \\
\hline Exploração & 1.681 .76 & 73.99 \\
\hline Estradas & 14.640 & 0.64 \\
\hline $\begin{array}{l}\text { Reseva Florestal + APP } \\
+ \text { Brejo }\end{array}$ & 151.560 & 23.52 \\
\hline $\begin{array}{l}\text { Área Comunitária - Cen- } \\
\text { tro de Equipamentos }\end{array}$ & 42.290 & 1.85 \\
\hline $\begin{array}{l}\text { Área total do Assenta- } \\
\text { mento }\end{array}$ & 2.290 .26 & 100 \\
\hline
\end{tabular}

Fonte: Elaborado pela autora a partir do levantamento de campo 2013.

13 Através de uma entidade jurídica representada por associação formalizada com CNPJ. 
Os assentamentos rurais, sejam eles de origem federal ou estadual são representações espaciais da operação de políticas públicas voltadas à promoção da fixação dos agricultores familiares nesse tipo de comunidade. Os dados levantados nas visitas aos escritórios do INCRA e do ITESP permitiram não só responder como são projetados os assentamentos rurais em São Paulo, mas também sistematizar dados federais e estaduais especializados no Estado reconhecendo as regiões caracterizadas por esse tipo de ocupação. As dificuldades operacionais e burocráticas inviabilizam o cumprimento de todas as etapas que compõem o planejamento e a organização, principalmente a execução do PDA, o que acaba gerando a reprodução de um parcelamento independentemente da região, do grupo de famílias ou das características físicas que cada área pode ter.

Como a maioria dos projetos implantados ocorreram a partir de ações federais, as implantações seguem o padrão xadrez de parcelamento do solo. Podem ser verificadas outras experiências como as primeiras agrovilas, as rodas de carroça e os assentamentos, que são projetados pelo programa, considerando como premissa de projeto um desenvolvimento que se organiza a partir das características físicas e ambientais da área a ser ocupada.

O levantamento das ocorrências no Estado de São Paulo permitiu identificar os três principais programas, disponibilizados nas diferentes instâncias governamentais, com diretrizes que geram as implantações em regiões que se caracterizam por esse tipo de ocupação. Os assentamentos rurais, sejam eles de origem federal ou estadual são representações espaciais da operação de políticas públicas voltadas a promoção da fixação dos agricultores familiares nesse tipo de comunidade. Os dados levantados nas visitas aos escritórios do INCRA e do ITESP permitiram não só responder como são projetados os assentamentos rurais em São Paulo, mas também sistematizar dados federais e estaduais especializados no Estado reconhecendo as regiões caracterizadas por esse tipo de ocupação. 


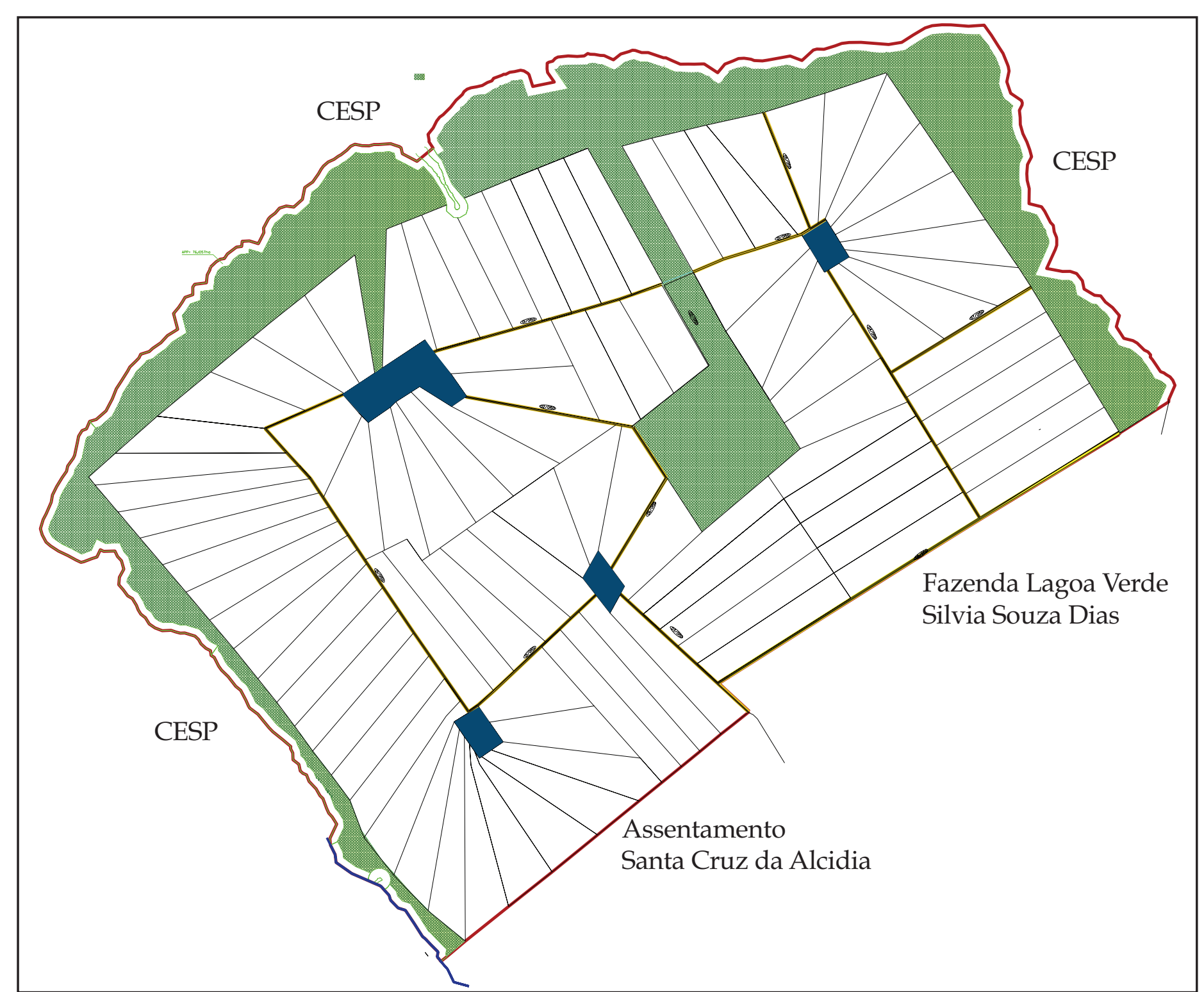

Figura 7: Projeto Estadual - PE Padre Josimo: roda de carroça

\section{Legenda}

- Perimetro Padre Josimo

- Áreas comunitárias Vias

。ǒ̆ŏ Reserva florestal Permanente

- Rios e córregos

CESP: Companhia de Energia de São Paulo

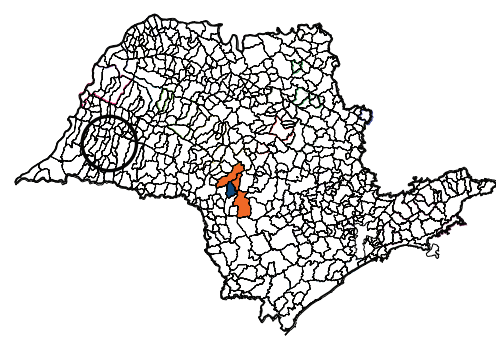

Município: Teodoro Sampaio
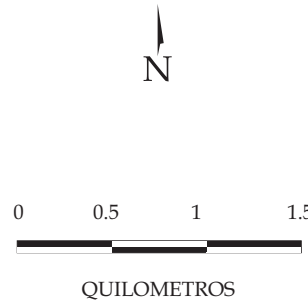

Fonte: ITESP 
As dificuldades operacionais e burocráticas inviabilizam o cumprimento de todas as etapas que compõe o planejamento e a organização principalmente a execução do PDA o que acaba gerando a reprodução de um parcelamento independentemente da região, do grupo de famílias ou das características físicas que cada área pode ter.

Tendo sido a maioria dos projetos sido implantados a partir de ações federais as implantações seguem o padrão xadrez de parcelamento do solo. Podem ser verificadas outras experiências, as primeiras agrovilas, as rodas de carroça e os assentamentos que são projetados pelo programa que considera como premissa de projeto um desenvolvimento que se organiza a partir das características físicas e ambientais da área a ser ocupada. 


\section{Capítulo 3}

\section{Condicionantes do Ambiente Construído}

\subsection{Criação do projeto de assentamento Zumbi dos Palmares}

Os procedimentos de pesquisa foram orientados para o estudo a partir dos tipos de projetos de assentamento rural implantados em São Paulo, e à luz da experiência de criação e implantação do projeto de assentamento Zumbi dos Palmares em Iaras/SP. A escolha desse assentamento como objeto de estudo deveu-s primeiramente, ao fato de ter sido também objeto das atividades que desenvolvi como arquiteta da equipe que operava o programa piloto de provisão de moradia nos assentamentos federais de São Paulo. Além disso, esse assentamento é um projeto federal - o tipo mais implantado em SP nos últimos quase 30 anos - e que, por isso, teve suas ocupações orientadas pelas diretrizes dos dois planos nacionais publicados e que orientaram a política de reforma agrária no país.

As duas primeiras fases de implantação foram orientadas pelo I PNRA. A promulgação do segundo plano, em 2003, orientou a ocupação das novas áreas que foram parceladas a medida em que se desenrolava o processo de obtenção da terra. As famílias assentadas a partir do segundo plano puderam se estabelecer de forma mais organizada, pois contaram o apoio de créditos dos programas disponibilizados via assistência técnica locada nos escritórios regionais, resultado do aprimoramento das 
políticas compensatórias que visam à fixação dessas famílias no meio rural.

A extensão da fazenda e a forma de obtenção da terras implicram diferentes fases de parcelamento da área gerando condições de reconhecer, na organização dos lotes, as formas tradicionais de parcelamento: o xadrez ou a espinha de peixe. Mas também é possível reconhecer o parcelamento diferenciado, com lotes menores, organizados próximo a uma centralidade conformando uma agrovila.

No primeiro capítulo, a análise dos dois Planos Nacionais de Reforma Agrária, promulgados em 1985 e 2003, orientou a compreensão acerca de como têm sido projetados e implantados os assentamentos rurais em São Paulo. Do ponto de vista crítico, pode-se reconhecer como indicador de mudança do primeiro para o segundo Plano, a elaboração dos projetos a partir de diretrizes mais específicas, seja por questões ambientais - definidas pela nova legislação -, seja por demanda das famílias beneficiadas que, organizadas, colaboram com a definição do anteprojeto do parcelamento, gerando assentamentos que se diferenciam pela estratégia de projeto. O conhecimento adquirido com as experiências obtidas nos últimos 30 anos também têm influenciado as novas implantações.

Durante a pesquisa identificou-se que o modelo de assentamento mais implantado em São Paulo é o parcelamento do tipo "xadrez/espinha de peixe" - o qual parece não considerar a relação entre a dimensão da área ocupada e as condições do cotidiano das famílias. Toma-se como exemplo a experiência na operação do programa de moradia rural. As dificuldades encontradas na construção das casas - organizadas por um programa de disponibilização de recursos para aquisição de material - ultrapassaram as esferas políticas e sociais que permeiam o processo, além e aquém das burocracias. Foi possível perceber durante a experiência que aqui é tomada como referencial de trabalho, fatores 
contraditórios do processo de materialização do programa. Pode-se citar como exemplo as divergências entre o roteiro de operacionalização e prática das atividades em campo e o que era possível de ser executado e atendido na realidade do assentamento, tendo em vista não só as dificuldades técnicas de execução das obras, mas também as distâncias percorridas para aquisição e entrega do material, da entrada do lote ao local da construção, entre outros fatores como a organização de grupos que não considerou a proximidade das casas, ou relações sociais anteriores.

\subsubsection{Construção do Assentamento}

Considerando-se o processo histórico, as características socioeconômicas do país e as experiências recentes, nota-se que foi nos últimos dez anos que o meio rural da agricultura familiar nos assentamentos passou a fazer parte do rol investimentos públicos. No entanto, percebe-se, que ainda, que no desenho das políticas públicas para organização desse lugar que também vem sendo tratado com poucas adaptações em relação ao meio urbano.

A pesquisa realizada durante os meses de fevereiro a junho de 2012, no INCRA/SR08 e no ITESP/SP, confirmou que o momento de entrada no assentamento é geralmente marcado por rupturas, nas quais as contradições e os conflitos suscitados pela convivência do grupo geram simbolismos coletivos que se refletem na paisagem. Por exemplo: a opção por lotes individuais de produção e moradia interfere na relação de proximidade experimentada na fase do acampamento. A vida no assentamento é permeada por práticas que implicam a interação do grupo. São atividades em parceria que visam promover a fixação das famílias 
e que acabam determinando condições específicas da vida social.

O assentamento na sua constituição formal - processo de criação - não pode ser entendido ou considerado como um bairro, uma vez que este é definido como organização coletiva de trajetórias individuais; ou seja, no bairro, os "lugares" atendem as necessidades cotidianas. No assentamento, ainda que este resulte de uma organização coletiva de trajetórias individuais, os lugares que se constituem na sua implantação, não atendem, necessariamente, as necessidades cotidianas. A ausência de escolas, postos de saúde e oferta de pequenos serviços são comuns nos assentamentos paulistas, e indicam o não atendimento dessas funções. Além disso, a escala do assentamento é diferente daquela observada nos bairros urbanos, principalmente no que se refere à densidade habitacional, densidade construída e infraestrutura instalada.

\section{2 Escalas de Abordagem}

Para analisar o projeto estabelecido no processo de criação e a resultante de implantação, da mesma perspectiva, foram estabelecidas escalas de abordagem e critérios de análise a partir dos indicadores e das variáveis sugeridas na pesquisa INCRA/UNIARA, organizados para uma análise do ponto de vista da arquitetura do assentamento:

1. MACRO: aborda a origem da terra inserida no âmbito regional e contexto nacional, tendo em vista a compreensão da inserção da região no Estado de São Paulo, os vizinhos do assentamento;

2. MÉDIA: apresenta as etapas da ocupação, define-se o conceito de módulo ruralli6; é 
a escala que busca compreender a forma de parcelamento dos lotes na construção do assentamento e também a dinâmica com a cidade. Nesse ponto, verificam-se a evolução do parcelamento com a ocupação de novas áreas e as alterações de capacidade e usos, bem como a evolução da população rural no município desde a primeira etapa da ocupação;

3. MICRO: analisa o perfil das famílias, a variação do tamanho dos lotes, as propostas de uso do solo e a relação com o meio ambiente.

Os dados e as informações para a primeira parte da análise foram obtidos no levantamento realizado nas divisões do INCRA, em São Paulo, e no escritório de apoio técnico em Iaras, a partir da leitura e registro do processo de criação formal; de conversas com os técnicos das diferentes divisões envolvidos na criação do Zumbi dos Palmares; e também da revisão bibliográfica. A tabela 5 apresenta os indicadores e as variáveis que orientaram a organização das escalas de abordagm. 
Tabela 5: Indicadores e variáveis para análise da criação e implantação do assentamento rural

\begin{tabular}{|c|c|c|c|c|c|}
\hline \multicolumn{6}{|c|}{ e critérios de análise } \\
\hline Indicadores & Variáveis & Envolvidos & Primários & Secundários & Técnica \\
\hline ORIGEM & \begin{tabular}{|l} 
Desapropração \\
Solo
\end{tabular} & $\begin{array}{l}\text { INCRA, Movimentos } \\
\text { Sociais, Assentados }\end{array}$ & $\begin{array}{l}\text { Visita ao lote, } \\
\text { entrevista com } \\
\text { coordenadores } \\
\text { do INCRA e } \\
\text { membros do } \\
\text { movimento social }\end{array}$ & $\begin{array}{l}\text { Solcititação de dados na } \\
\text { sede do INCRA/SP }\end{array}$ & $\begin{array}{l}\text { Diário de campo } \\
\text { e entrevistas, } \\
\text { pesquisa } \\
\text { documental }\end{array}$ \\
\hline DADOS ESPACIAIS/FÍSICOS & \begin{tabular}{|l|} 
Dist. Municipios \\
Área total \\
APP/RL \\
Área média do lote \\
\end{tabular} & Prefeituras, INCRA & & $\begin{array}{l}\text { Solcititação de dados na } \\
\text { sede do INCRA/SP }\end{array}$ & $\begin{array}{l}\text { Diário de campo } \\
\text { e entrevistas, } \\
\text { pesquisa } \\
\text { documental }\end{array}$ \\
\hline INFRAESTRUTURA & \begin{tabular}{|l|} 
escolas/nivel \\
Porto de Súde \\
Estradas \\
Transporte \\
Coleta de Lixo \\
Iluminaçăo pública e telefonia \\
\end{tabular} & INCRA e Assentados & $\begin{array}{l}\text { Coordenador de } \\
\text { Campo INCRA, } \\
\text { Assentados }\end{array}$ & $\begin{array}{l}\text { Solcititação de dados na } \\
\text { sede do INCRA/SP }\end{array}$ & $\begin{array}{c}\text { Diário de campo } \\
\text { e entrevistas, } \\
\text { pesquisa } \\
\text { documental }\end{array}$ \\
\hline INDICADORES SOCIAIS & \begin{tabular}{|l|} 
SIPRA \\
CENSO 2006 \\
Cadastro Acampamento \\
\end{tabular} & INCRA, MDA, IBGE & & $\begin{array}{l}\text { Levantamento de dados } \\
\text { pela internet e no INCRA }\end{array}$ & $\begin{array}{c}\text { Pesquisa } \\
\text { Documental }\end{array}$ \\
\hline $\begin{array}{l}\text { PRODUÇÃO/ORGANIZAÇÃO/ } \\
\text { RENDA }\end{array}$ & \begin{tabular}{|l|}
$\begin{array}{l}\text { Principais produçōes } \\
\text { ocmerciais }\end{array}$ \\
Principais produçōes para \\
autoconsumo/Origem da \\
renda
\end{tabular} & $\begin{array}{l}\text { INCRA, Assentados, } \\
\text { IBGE }\end{array}$ & $\begin{array}{l}\text { Assentados, } \\
\text { Coordenadores } \\
\text { de campo e } \\
\text { técnicos do } \\
\text { INCRA }\end{array}$ & $\begin{array}{l}\text { Solcititação de dados ao } \\
\text { INCRA e levantamento de } \\
\text { dados pela internet }\end{array}$ & $\begin{array}{l}\text { Diário de campo } \\
\text { e entrevistas, } \\
\text { pesquisa } \\
\text { documental }\end{array}$ \\
\hline POLITICAS PÚBLICAS & \begin{tabular}{|l|} 
PRONAF A e C/outros/Custeio \\
Apoio Mulher \\
Luz para todos \\
Moradia \\
Acesso a água e saneamento \\
Estradas \\
Renegociaçăo de dividas \\
Assistência técnica \\
PAA/PNAE \\
Bolsa Familia \\
Agroindústria \\
\end{tabular} & INCRA & $\begin{array}{l}\text { Coordenadores e } \\
\text { técnicos do } \\
\text { INCRA }\end{array}$ & $\begin{array}{l}\text { Levantamento de dados } \\
\text { pela internet: sites } \\
\text { CONAB, MDA, INCRA }\end{array}$ & $\begin{array}{c}\text { Diário de campo } \\
\text { e entrevistas, } \\
\text { pesquisa } \\
\text { documental }\end{array}$ \\
\hline
\end{tabular}

Fonte: Pesquisa INCRA/UNIARA, 2012 adaptado pela autora 


\subsubsection{Origem da Terra}

Tendo sido criado em 1998, o assentamento Zumbi dos Palmares teve suas premissas de parcelamento apoiadas nas diretrizes do I PNRA. Inscrito na zona rural do município de Iaras teve sua evolução atrelada a um processo de retomada do controle fundiário a partir da obtenção de terras por meio de desapropriações. Durante os 15 anos que se seguiram à implantação, a capacidade do assentamento foi revisada mais de sete vezes. O resultado desse processo, por parte do INCRA, naquela região foi iniciado posteriormente ao reconhecimento de Iaras como município, cuja evolução esteve condicionada à evolução urbana de uma das áreas ocupadas no parcelamento do Núcleo Colonial Monções.

O parcelamento do Núcleo ocorreu em 1909, quando o governo federal recebeu, por conta de um processo contra a Cia São Paulo Paraná ${ }^{18}$ algumas fazendas na região. No ano seguinte outras fazendas foram compradas pelo governo que, de posse de uma área de 40 mil hectares, elaborou um projeto de assentamento dirigido à colonos imigrantes - europeus e asiáticos - para que pudessem produzir para o consumo próprio e comércio local.

A movimentação em torno dessas áreas também esteve ligada à dinâmica da região de Botucatu, influenciada, em grande parte, pela operação da Estrada de Ferro Sorocabana que transportava o café produzido nas fazendas do oeste paulista até o porto de Santos, onde era exportado.

Também implantado em etapas, o parcelamento dos lotes do NCM promoveu a ocupação em duas áreas - inseridas no perímetro total das fazendas da união - distantes entre si. 
[...] em 1994 a prefeitura municipal de Iaras solicita ao INCRA a regularização das terras já que o perímetro urbano da cidade trata-se de uma das agrovilas do núcleo que se desenvolveu. O Núcleo foi implantado em duas agrovilas, uma na área da antiga fazenda Santa Luzia - porção sul do núcleo - e outra na fazenda Turvinho, localizada na porção norte. O município de Iaras foi fundado na agrovila do sul, pois a do norte foi abandonada. (RO-

MANO, 2009).

Os lotes agrícolas das partes norte e sul foram vendidos. Entretanto a parte de terras referentes à Fazenda Capivara, localizada entre os dois parcelamentos, foi mantida como propriedade da União, sem uso definido, sem ocupação e, consequentemente, sem a fiscalização do Estado. No início da década de 1960, o distrito de Iaras recebe autonomia político-administrativa. Nessa época, o então presidente declarou a intensão de transferir as propriedades de suas terras para o Estado de São Paulo. Mesmo sem a documentação de transferência, o Instituto Florestal de São Paulo ocupou, com a implantação de um horto florestal, uma área remanescente do perímetro do Núcleo.

Nas figura 8 está identificado o conjunto de fazendas adquiridas inseridas no contexto da região e do município de Iaras.

Em 1993, o INCRA recebeu uma reivindicação do registro de terras na região. Dessa vez, um posseiro exigindo o registro de suas terras, afirmava estar na área desde a década de 1970. Isso obrigou o INCRA a realizar um estudo de origem dominial do qual resultou na comprovação da propriedade das terras em seu favor. Considerando que a ocupação do assentamento tenha sido realizada em uma parte da área remanescente do Núcleo, e que tenham sido abandonados os lotes da porção norte, o projeto do assentamento Zumbi dos Palmares, constituído na área da Fazenda Capivara, remanescente do NCM, será analisado a partir do levantamento da série histórica de seu processo de criação, e tendo como referência a experiência de parcelamento rural implantada anteriormente na região.
18 Companhia Ferroviária São Paulo-Paraná 1923-1944. 
Propõe-se o entendimento sequenciado desde a origem dessa terra, passando pela espacialização do parcelamento com a ocupação dos primeiros lotes; e, a cada etapa, especializando as informações levantadas e entendidas como as condicionantes desse tipo de organização no decorrer dos últimos quinze anos.

Dessa perspectiva, estabeleceram-se relações possíveis entre a origem da terra, o parcelamento e a espacialização da ocupação, definindo as condicionantes da organização desse ambiente socialmente construído, de forma a extrair um entendimento sobre as evoluções no tempo, as mudanças no uso do solo, a variação do tamanho dos lotes, as conexões com o entorno regional e a relação com a questão ambiental.

A falta de controle fundiário, por parte do Estado, em relação às terras do território nacional, é um nó que teve origem no meio rural, sendo reproduzido nas cidades nos processos de urbanização. De certa forma, essa problemática é retomada na implantação dos assentamentos rurais, a partir de 1985, com a criação do I PNRA. A figura 9 ilustra o parcelamento do Núcleo Colonial Monções e a Fazenda Capivara inseridos no contexto do município de Iaras.

Em São Paulo, o Assentamento Zumbi dos Palmares (AZUP) é um dos reflexos desse nó. Foi criado institucionalmente, em 1998, quando as terras da Fazenda Capivara foram destinadas ao assentamento de famílias sem-terra, beneficiárias do I PNRA.

A leitura do processo de criação do AZUP e a organização das informações do levantamento de campo permitiram a definição de critérios de análise para compreender a forma de espacialização. A composição de ilustrações com a espacialização das informações do processo de criação, e a sobreposição do projeto de parcelamento às imagens de satélite permitiram tanto interpretar a evolução como identificar as alterações ocorridas durante os 


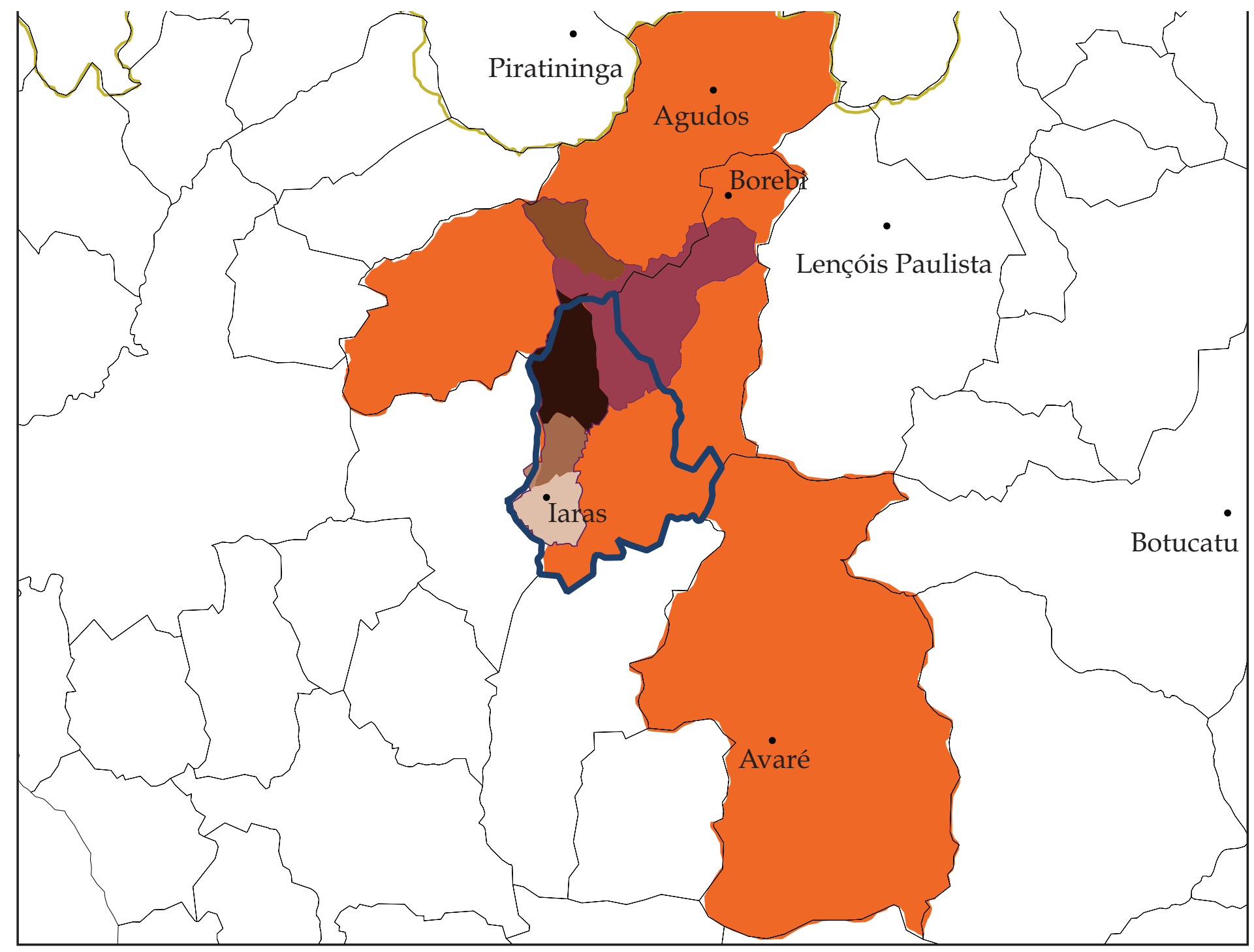

Limites de municípios

Região central Iaras

- Município de Iaras

Fazendas Forquilha, Geada e Salto

Fazenda Turvinho

- Fazenda Capivara

- Fazenda Capão Rico

Sitio Sandy

Fazenda Santa Luzia

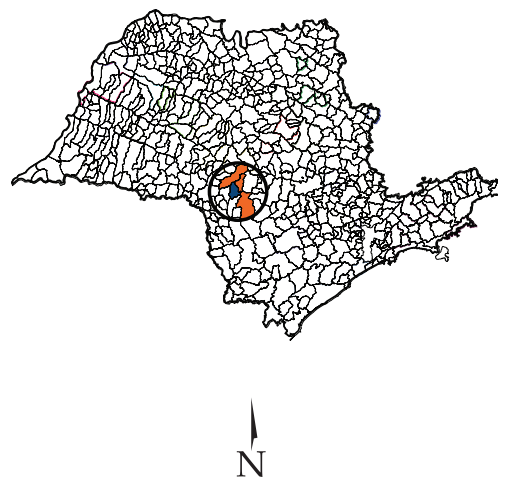

Figura 8: Fazendas adquiridas que constituíram o Núcleo Colonial Monções na região de Iaras. IBGE/INCRA, 2013 
diferentes momentos de alteração nas variáveis das condicionantes desse ambiente socialmente construído.

A identificação do perímetro do Núcleo Colonial Monções permite compreender a inserção da Fazenda Capivara no conjunto fazendas que formam o núcleo. Parcelada e ocupada, a partir de 1998, com a criação do assentamento Zumbi dos Palmares. Localiza-se no município de Iaras e está inscrita no perímetro do NCM.

No ano de 1910 - início do Núcleo Colonial Monções -, a sede da fazenda comprada pelo governo se torna o centro do núcleo, começando o pequeno povoado denominado Monção, tendo sido seu fundador o Sr. Pinheiro Machado. Em 1911, o governo federal criou e implantou no povoado, o Patronato Agrícola de Monção, com o objetivo de abrigar e reeducar os menores abandonados da cidade do Rio de Janeiro e explorar uma parte das terras. Com isso vieram investimentos em infraestrutura, que serviriam para abrigar os menores e os funcionários, o que gerou assim alguns empregos e desenvolvimento local (XAVIER apud MARTINS, 2010).

Em 1930, Patronato é fechado, impactando no desenvolvimento do povoado. Retomado em 1942, sob a denominação de Instituto de Menores de Iaras, tornou-se, com o passar dos anos, uma das unidades da Fundação Estadual do Bem-Estar do Menor (FEBEM). O povoado de Monção foi distrito de Águas de Santa Bárbara e, em 1940, passou a chamar-se Iaras. No mesmo ano, recebeu distribuição da rede de energia elétrica.

\subsubsection{Cidade e Assentamento}


Na história de Iaras, além do AZUP, há o registro de outra fo dar uso às terras remanescentes, implantou o Patronato Agrícola de Monção, "que visava abrigar menores abandonados provenientes do Rio de Janeiro e criar possibilidades de se explorar terras remanescentes da antiga fazenda" (SEADE, 2013, p.1). No entanto, não foram encontrados registros sobre área ocupada.

A sequência de ações públicas e a prática da agricultura familiar de subsistência promoveram o desenvolvimento da parte sul do Núcleo Colonial Monção, que depois passou a ser distrito Iaras, inserido no município de Águas de Santa Bárbara. No entanto, a destinação parcial das terras, e a frágil titulação que se estabeleceu com a ocupação, propiciaram que remanescentes do NCM ficassem sem uso específico, dando início à problemática fundiária local.

\begin{abstract}
A falta de registro do processo fundiário acarretou na constituição do município sem a documentação das propriedades municipais. Nas proximidades algumas propriedades rurais e lotes urbanos são aqueles vendidos pela Uniã̃o entre 1910 e 1918, esses, foram registrados e não fazem parte das propriedades da União (ROMANO, 2009).
\end{abstract}

A tabela 6 apresenta a evolução da população do município indicando o reflexo da implantação do assentamento, a chegada das famílias em 1996, na fase de acampamento, implicou aumento da população rural do município. De acordo com o IBGE (2013) a população rural de Iaras é de 3.539 das quais cerca de 1486 vivem no AZUP. São 377 lotes demarcados no projeto, estima-se uma média de quatro pessoas por lote.

Pode-se dizer que o aumento populacional observado entre os anos de 2000 e 2010 é resultante da inserção de mais famílias no assentamento Zumbi dos Palmares desde sua criação em 1998. 


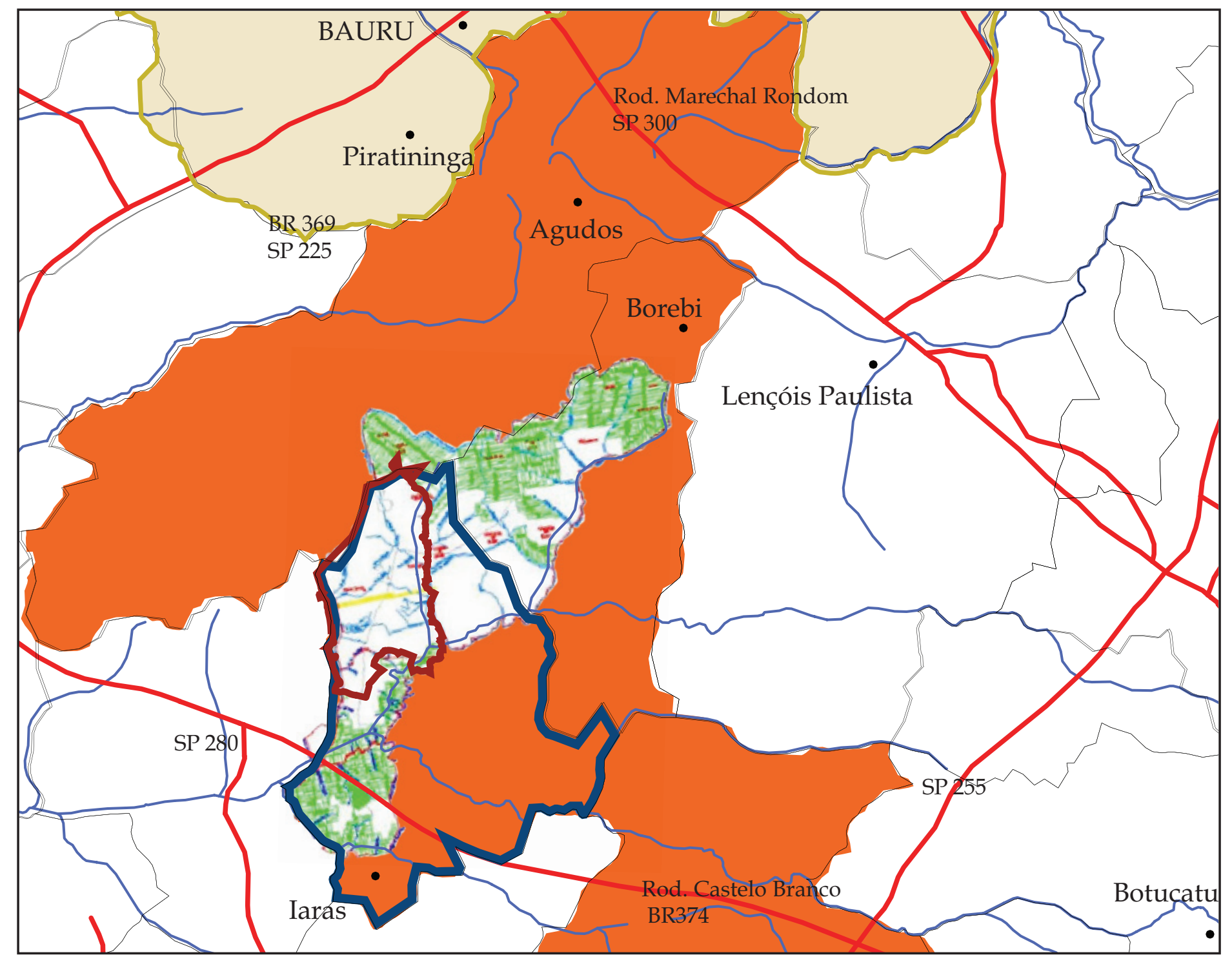

Legenda

- Municipio de Iaras

- Parcelamento Núcleo

Colonial Monções

- Projeto de assentamento

Zumbi dos Palmares

Região central

- Vias

— Rios e córregos

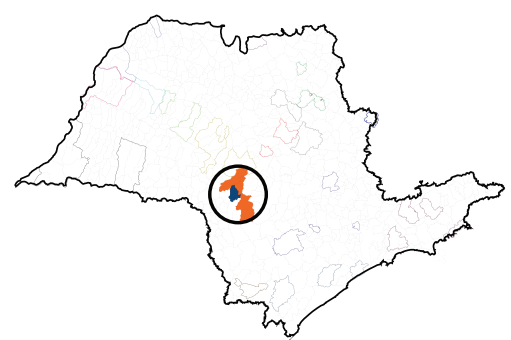

N

Figura 9: Ocupação Norte e Sul do Núcleo Colonial Monções na região de Iaras. Indicação da Fazenda Fonte: elaborado pela autora, Capivara onde foi criado o assentamento Zumbi dos Palmares. IBGE/INRCRA, 2013. 
Ainda que na definição do SEADE o grau de urbanização ${ }^{19}$ da cidade seja de $44,50 \%$, em 2010 , ele fica 51,44 pontos abaixo da taxa estadual $(95,94 \%)$, e 40,58 pontos abaixo de sua região administrativa $(85,08 \%)$, que inclui Avaré, o que indica que a maioria da população reside no zona rural. Considerando-se ainda, que a população no assentamento ultrapassa a faixa de mil habitantes ${ }^{20}$, pode-se classificar o município de Iaras como de população predominantemente rural, que se desenvolveu no contexto da agricultura familiar de assentamento rural. A tabela 6 apresenta população rural de Iaras por faixa etária, a maioria da população rural está entre os 15 e 49 anos, seguido da população infantil.

A famílias que vivem no AZUP representam cerca de $42 \%$ da população rural total do município. O Índice de Desenvolvimento Humano (IDH) do município passou de 0,742, ficando pouco abaixo do IDH estadual, que ficou em 0,814, para 0,674, em 2010 segundo o IBGE de 2010. A Fundação SEADE que calcula o Índice Paulista de Responsabilidade Social (IPRS) nas dimensões de "Riqueza, Longevidade e Escolaridade" coloca o município no grupo 4 - municípios mais desfavorecidos - tanto em riqueza como nos indicadores sociais. Ou seja, em comparação com o Estado, os índices de riqueza, longevidade e escolaridade estão abaixo da média. Isto indica que o município de Iaras possui poucos investimentos nas as áreas da saúde e da educação dos seus habitantes, o que se reflete no assentamento que, até 2013, não tinha escola para atender a população residente.

De acordo com os dados de 2013 da Fundação SEADE, a porcentagem dos vínculos empregatícios e o rendimento destes na agropecuária, são maiores que o estadual e o regional, considerando-se que os trabalhadores rurais do AZUP têm participação - são 377 famílias (2013) que trazem investimentos para a agricultura e pecuária. Nos anos de 2006 e 2007 foram contratados pelo PRONAF cerca de R\$2.805.000,00, para as 170 famílias assentadas no ano de 2005. (SOUZA, F. S. et. al., 2012). Em 2005, 172 famílias receberam o crédito
Tabela 6: Iaras - população e município

\begin{tabular}{|l|l|}
\hline \multicolumn{2}{|c|}{ População/ano } \\
\hline 2013 & 7.431 \\
\hline 2010 & 6.376 \\
\hline 2007 & 4.777 \\
\hline 2000 & 3.054 \\
\hline 1996 & 2.162 \\
\hline \multicolumn{2}{|c|}{ Características do Município } \\
\hline $\begin{array}{l}\text { Área da unidade territo- } \\
\text { rial }\left(\mathrm{k} \mathrm{m}^{2} \text { ) }\right.\end{array}$ & 401,307 \\
\hline $\begin{array}{l}\text { Densidade demográfica } \\
\text { (hab/km² }\end{array}$ & 15,89 \\
\hline Bioma & Cerrado \\
\hline
\end{tabular}

Fonte: IBGE, 2013 adaptado. 


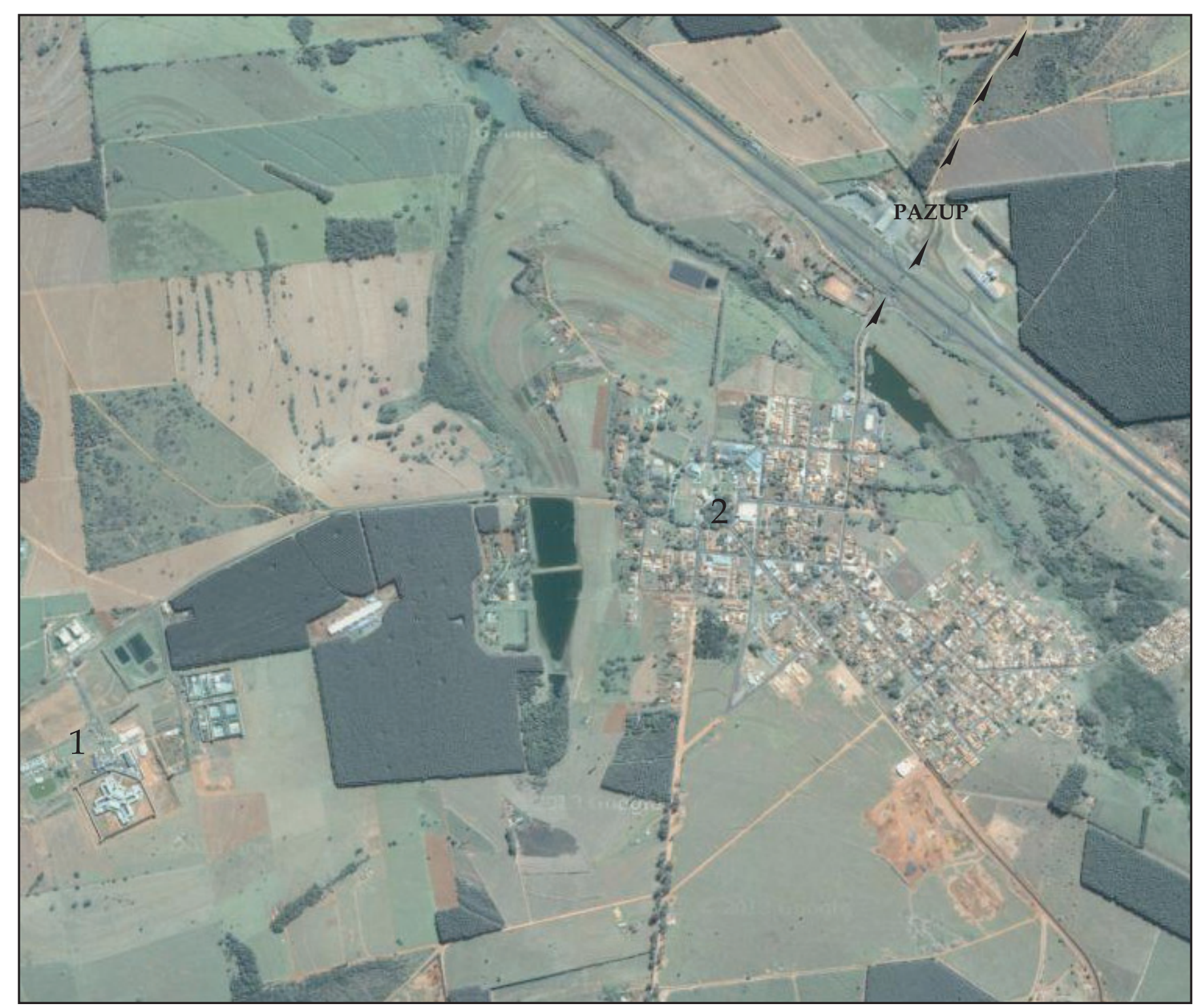

Figura 10: Vista da cidade de Iaras.
Legenda

1- Penitenciária Estadual

2- Praça Monções

- Rota Cidade de Iaras PAZUP

Tabela 7: População rural Iaras

\begin{tabular}{|l|c|}
\hline 0 a 4 anos & 153 \\
\hline 5 a 9 anos & 166 \\
\hline 10 a 14 anos & 198 \\
\hline 15 a 19 anos & 435 \\
\hline 20 a 24 anos & 240 \\
\hline 25 a 29 anos & 279 \\
\hline 30 a 39 anos & 748 \\
\hline 40 a 49 anos & 632 \\
\hline 50 a 59 anos & 410 \\
\hline 60 a 69 anos & 185 \\
\hline $\begin{array}{l}70 \text { anos ou } \\
\text { mais }\end{array}$ & 93 \\
\hline Total & 3.539 \\
\hline
\end{tabular}

Fonte: IBGE, 2013 adaptado.

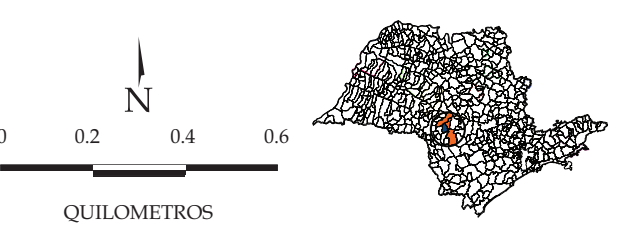

Fonte: Google earth, 2014 
Fomento, um investimento no valor de $\mathrm{R} \$ 2.400,00$ para estruturação da produção do lote, gerando um total de $\mathrm{R} \$ 408.000,00$, que foram gastos no comercio local.

O AZUP foi criado pela portaria INCRA/SR (08) / / n055 de 16 de setembro de 1998 em uma parte das terras da Fazenda Capivara - remanescente do NCM - , com previsão de criação de 71 unidades agrícolas familiares, no entanto verifica-se no cadastro do Sistema de Informações de Projetos de Reforma Agrária (SIPRA) , que em 1998, foram inscritas 65 famílias, no entanto, foram parcelados 54 lotes. Destaca-se que no registro oficial são apontados casos de desistência, expulsão ou transferência para outro assentamento no mesmo período.

A figura 11 é o parcelamento do AZUP com destaque para a área na qual foram assentadas as primeiras famílias em 1998.

No mesmo ano, um processo de reconhecimento de posse em parte da área destinada ao assentamento resultou na concessão de Tutela Antecipada (TA) de 30\% da área da fazenda. A demanda pelo assentamento foi organizada em 1995 - ano do centenário de morte de Zumbi dos Palmares - quando famílias de diversas regiões do Estado de São Paulo, organizadas pelo Movimento dos Trabalhadores Rurais Sem Terra (MST), ocuparam parte da Fazenda Capivara. Em 1999 com a TA, o INCRA criou o Projeto de Assentamento Zumbi dos Palmares, constituído por 54 famílias.

Em 2003, os 70\% restantes da Fazenda Capivara foram incorporadas ao assentamento. A Tutela Complementar (TC) publicada gerou o parcelamento de outras unidades agrícolas passíveis de ocupação no assentamento, aumentando a capacidade de famílias assentadas e da área ocupada. Em 2005, acordos judiciais do INCRA possibilitaram o assentamento de mais 172 famílias.
19 Para o IBGE a taxa de urbanização é a percentagem da população da área urbana em relação à população total.

20 Estima-se que as famílias de trabalhadores rurais têm em média quatro pessoas. Multiplicando pelo total de lotes ocupados no AZUP, tem-se um aproximadamente 1500 pessoas. 
A incorporação da relação nominal destes novos beneficiários no SIPRA totalizam 226 unidades agrícolas em 2.370 hectares de produção, e mais 55 hectares em uma área destinada ao uso institucional para implantação da escola primária, de um posto de saúde, de uma área e esportiva cultural. Ainda que não tinham sido implantadas na época da criação constam no projeto de parcelamento como definição de uso do solo.

O ano de 2005 é marcado por uma sequência de alterações na capacidade do assentamento comprometendo a clareza do que se refere à capacidade e ao número de lotes realmente criados. Nota-se que outro critério que sofre alteração no decorrer desse período: há uma variação no tamanho da área do lote. Os lotes da primeira etapa foram demarcados com áreas entre 20 e 25 ha. No entanto, a presença de idosos e mulheres solteiras com filhos implicou a definição de um lote com dimensões reduzidas, foi chamado de pararrural o parcelamento de uma área vizinha à área institucional. São quase 60 lotes com áreas entre 4 e 5 hectares.

As famílias assentadas a partir de 2003 fazem parte da segunda etapa de ocupação do assentamento. Elas estão inseridas no contexto do II Plano Nacional de Reforma Agrária e contam com recursos e programas específicos para promover a sua fixação, como assistência técnica rural, diferentes modalidades de crédito, inclusive subsídios específicos para aquisição de material para construção de unidades habitacionais em alvenaria.

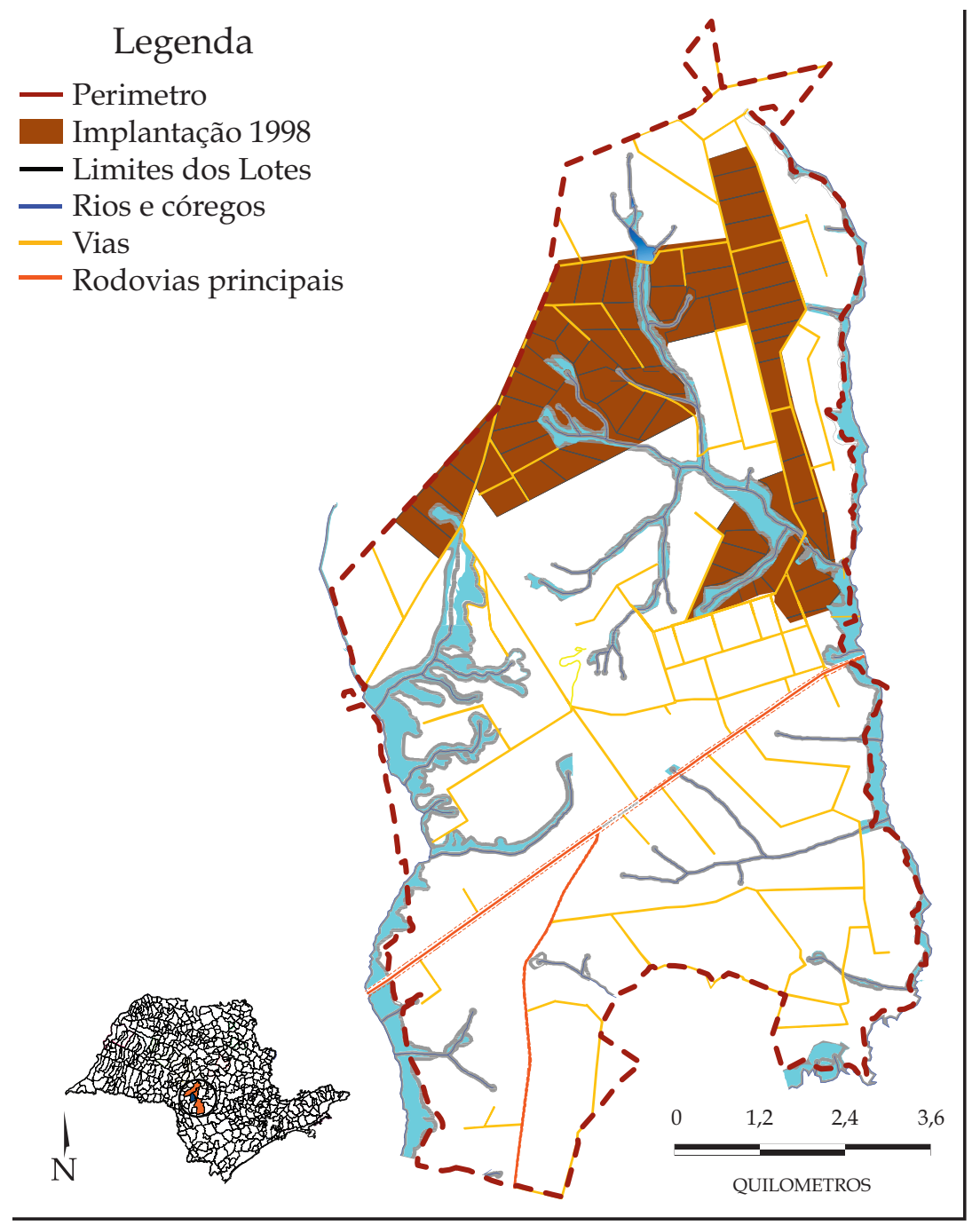

Figura 11: Destaque da área ocupada com o parcelamento 1998

Fonte: elaborado pela autora, 2013. 
O parcelamento do assentamento é o instrumento que espacializa as diretrizes e normativas os assentamentos do INCRA, por isso devem ser compatíveis com as características de cada região do país e devem estar de acordo com as legislações vigentes, incluindo a ambiental - 1999. Dessa maneira, os assentamentos criados antes de 1999, como é o caso do Zumbi dos Palmares, devem ter um levantamento para equacionar os passivos ambientais existentes.

Nesse caso, em 2000, o INCRA realizou o levantamento acerca do passivo ambiental do assentamento e verificou que $85 \%$ do solo estavam degradados, com apenas $15 \%$ de vegetação nas margens dos córregos em regeneração. Além disso, 80\% das famílias queimam o lixo de uso doméstico na área da habitação ou fora dela, as outras $20 \%$ enterram os dejetos no solo.

A condição dos ecossistemas terrestres não é diferentes, $75 \%$ já foram desmatados anteriormente e apenas 5\% encontra-se em estado primitivo. Depois de dois anos de implantação as primeiras famílias não se organizaram socialmente em cooperativas, essas só aparecem nos registros de 2012. No processo de criação, onde estão registradas as etapas do processo de implantação, não constam informações sore procedimentos participativos.

A implantação de assentamentos rurais por parte do INCRA segue, primeiramente, as diretrizes do Estatuto da Terra, em que se destaca o artigo $4^{\circ}$ que define, entre outras, as características do imóvel rural, de uma propriedade familiar, do módulo rural, do minifúndio e do latifúndio. A principal variante de um projeto de assentamento é a dimensão da área, definida no artigo $5^{\circ}$ conforme se destaca a seguir:

Art. $5^{\circ} \mathrm{A}$ dimensão da área dos módulos de propriedade rural será fixada para cada zona de características econômicas e ecológicas homogêneas, distintamente, por tipos de exploração rural que nela possam ocorrer. 
Além disso, o processo de assentamento do INCRA segue a orientação de instruções normativas - ou normas de execução (NE) -, que são instrumentos que regulamentam o trabalho dos técnicos para execução de suas ações.

O que se verifica no caso do processo de criação do Projeto de Assentamento (PA) do assentamento Zumbi dos Palmares é que, a partir do momento em que a área está liberada judicialmente, as etapas de licenciamento ambiental e o Plano de Desenvolvimento do Assentamento (PDA) - no qual deve constar a projeção de evolução do PA - não são cumpridas e muitas vezes, os beneficiários selecionados já "estão" na terra.

Diante da ausência de registro das outras áreas que faziam parte das fazendas do NCM, o processo de esclarecimento dominial da região resultou na incorporação de novas áreas, reconhecidas durante os dez anos seguintes da primeira fase de parcelamento. Esse fato resultou na expansão da área ocupada pelo assentamento com famílias nas mais diversas condições. Nas outras quatro alterações de capacidade, registradas no processo de criação do INCRA, aparecem outros usos no parcelamento, como por exemplo, áreas de preservação permanente - nas margens dos rios -, comunitária e institucional.

O projeto de parcelamento do Núcleo de Colonização é semelhante ao projeto de parcelamento dos assentamentos rurais inseridos no Plano de Reforma Agrária, pelo menos do ponto de vista do desenho de parcelamento resultante da forma de ocupar a área disponibilizada. Ao que parece, a diferença de 90 anos entre eles não implicou em um aprofundamento no estudo do parcelamento do solo. A pouca relação do parcelamento com o relevo é resultante da ocupação em etapas.

A organização do material levantado durante a pesquisa sistematizada por este trabalho alcança parte dos resultados pretendidos. De um lado, o levantamento de dados se-
Quadro 8: Passivo Ambiental Zumbi dos Palmares - 2000

\begin{tabular}{|l|l|}
\hline $\begin{array}{l}\text { Estado das margens } \\
\text { dos corpos d'água }\end{array}$ & $\begin{array}{l}\text { Estado de conser- } \\
\text { vação do solo }\end{array}$ \\
\hline $\begin{array}{l}\text { 45\% Com vegetação } \\
\text { preservada }\end{array}$ & $15 \%$ Conservado \\
\hline $\begin{array}{l}\text { 15\% Com vegetação } \\
\text { em regeneração }\end{array}$ & $85 \%$ Degradado \\
\hline $20 \%$ Desmatada & $\begin{array}{l}85 \% \text { Erosão lami- } \\
\text { nar }\end{array}$ \\
\hline $20 \%$ Com pastagens & $\begin{array}{l}10 \% \text { Erosão em } \\
\text { sulcos }\end{array}$ \\
\hline $\begin{array}{l}\text { 0\% Ocupada com } \\
\text { cultura }\end{array}$ & $\begin{array}{l}5 \% \text { Erosão em } \\
\text { voçoroca }\end{array}$ \\
\hline
\end{tabular}

Fonte: elaborado pela autora, INCRA, 2013. 
cundários demonstrou que não há clareza acerca das informações sobre a capacidade do assentamento e a quantidade de lotes parcelados na área. Por outro, os dados primários apontam informações relevantes para o entendimento da evolução da ocupação e das características físicas e ambientais do parcelamento que contribuem com a resultante do ambiente construído.

Por fim, compreende-se que as alterações da configuração espacial no decorrer dos últimos quinze anos são resultantes de um parcelamento em etapas, sem um planejamento objetivo ao desenvolvimento do assentamento. O parcelamento da antiga Fazenda Capivara nos últimos dois anos, evoluiu sobre parte da antiga Fazenda Capão Rico.

\subsubsection{A construção no assentamento: materialização do programa}

Considerando-se que o ambiente construído no caso dos assentamentos rurais é resultante da materialização de políticas e programas específicos, e analisando-se os projetos de algumas implantações paulistas, percebe-se que o caráter emergencial assumido desde sua criação é o que justifica a ausência de um programa elaborado de acordo com as necessidades de cada grupo. A distância entre o projeto e o ambiente construído prejudica não só a permanência da primeira geração, mas também o interesse da próxima na continuidade do projeto inicial.

Depois da entrada no lote, ainda com barracos de lona, as famílias dão início a uma nova fase: a vida no assentamento. Os primeiros recursos disponíveis são para organização 


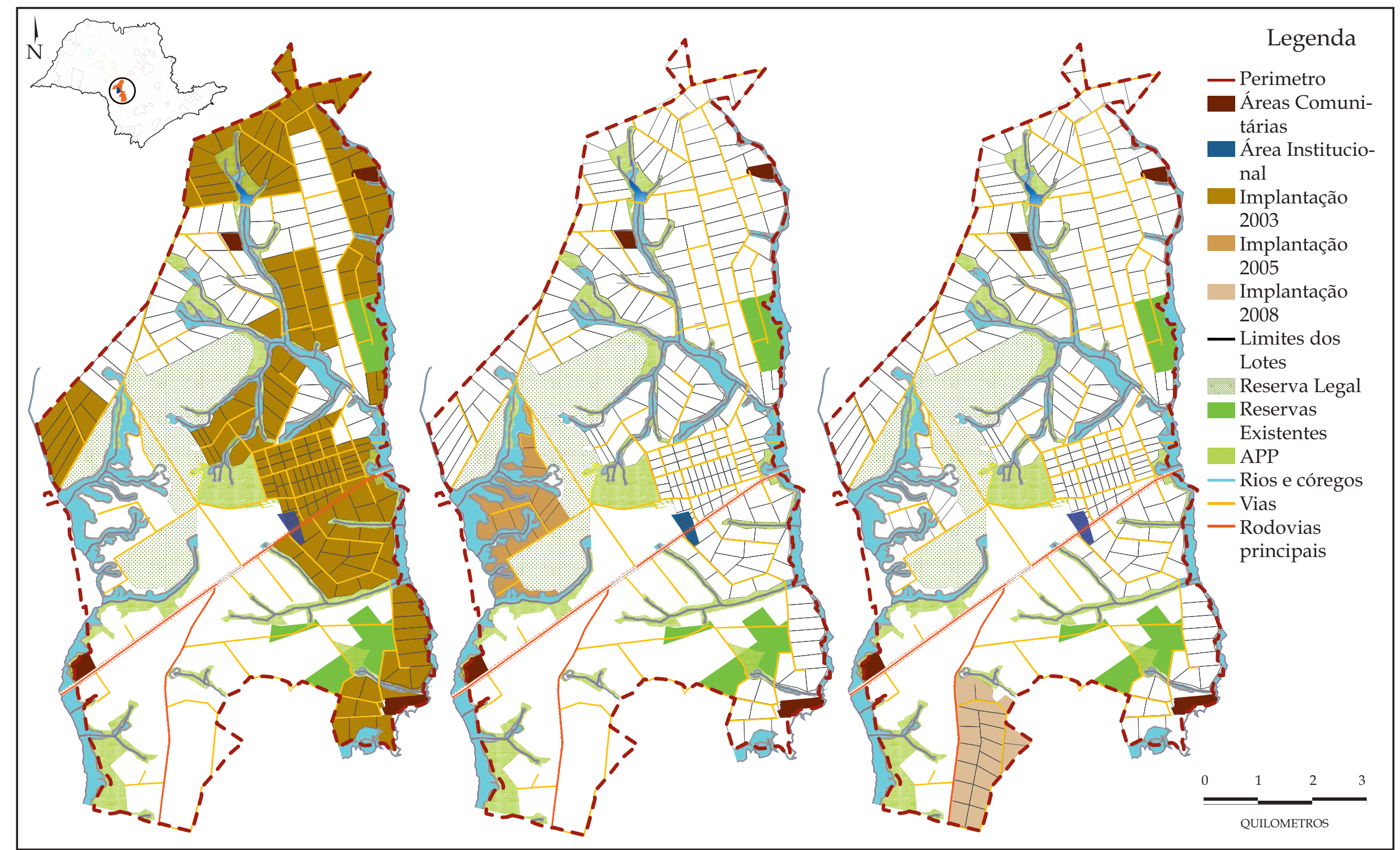

Figura 12: Destaque da área ocupada com o parcelamento 2003, 2005 e 2008 


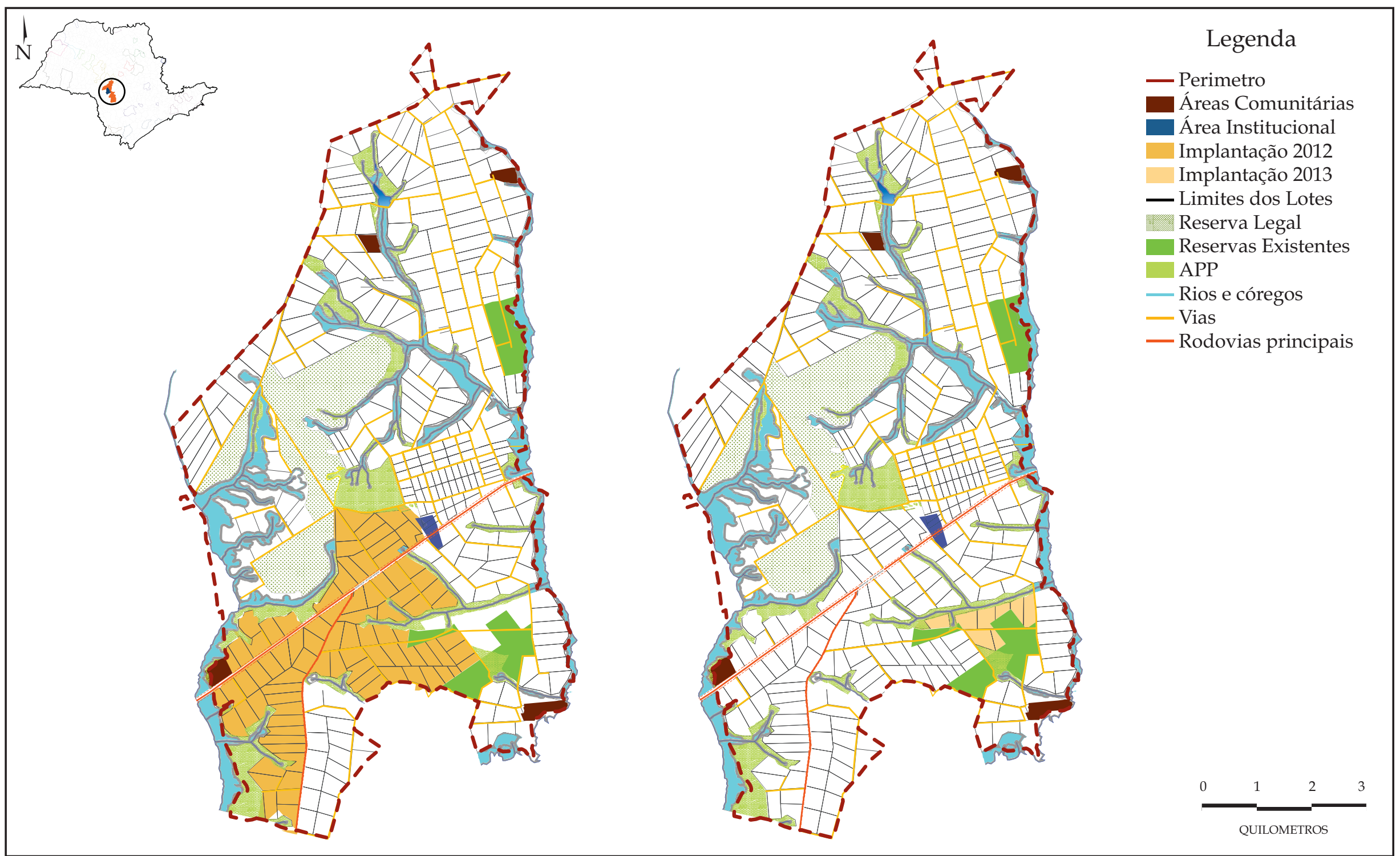

Figura 13: Destaque da área ocupada com o parcelamento 2012 e 2013 
do lote e início de plantio. Foi em 2006 que as famílias puderam construir ou reformar suas casas com os recursos disponíveis do Programa de Moradia Rural , tomado como referência neste capítulo para descrever como tem sido construído o ambiente no assentamento.

Implantado nos assentamentos federais no Estado de São Paulo, a partir de 2006, o programa piloto foi organizado para promover a construção de casas nos assentamentos paulistas. Objeto do acordo de cooperação e parceria entre o INCRA - através da Superintendência Regional de São Paulo SR (08) 21 - e a Caixa Econômica Federal (CEF), o acordo foi firmado com o objetivo de apoiar a "viabilização de moradia digna para os assentados beneficiados pelo Programa de Crédito Instalação do Ministério de Reforma Agrária do Estado de São Paulo" (INCRA SR08, 2007. p. 3). Esse acordo estava inserido no âmbito da resolução 460/200622 do Conselho Curador do Fundo de garantia por Tempo de Serviço (CC FGCTS).

A execução das obras previstas nesse acordo deveriam seguir as orientações do roteiro de operacionalização elaborado, de um lado, pela $\mathrm{CEF}$, com prática de financiamento para a construção de unidades habitacionais urbana, mas desconhecendo a realidade de construção no espaço rural; e, de outro pelo INCRA, inexperiente em relação aos instrumentos operacionais da CEF e talvez com maior conhecimento acerca da realidade rural. Previsto para ser executado entre seis e quatro meses, o programa não atingiu a meta prevista de construir, no período, as cerca de 3 mil unidades habitacionais contratadas.

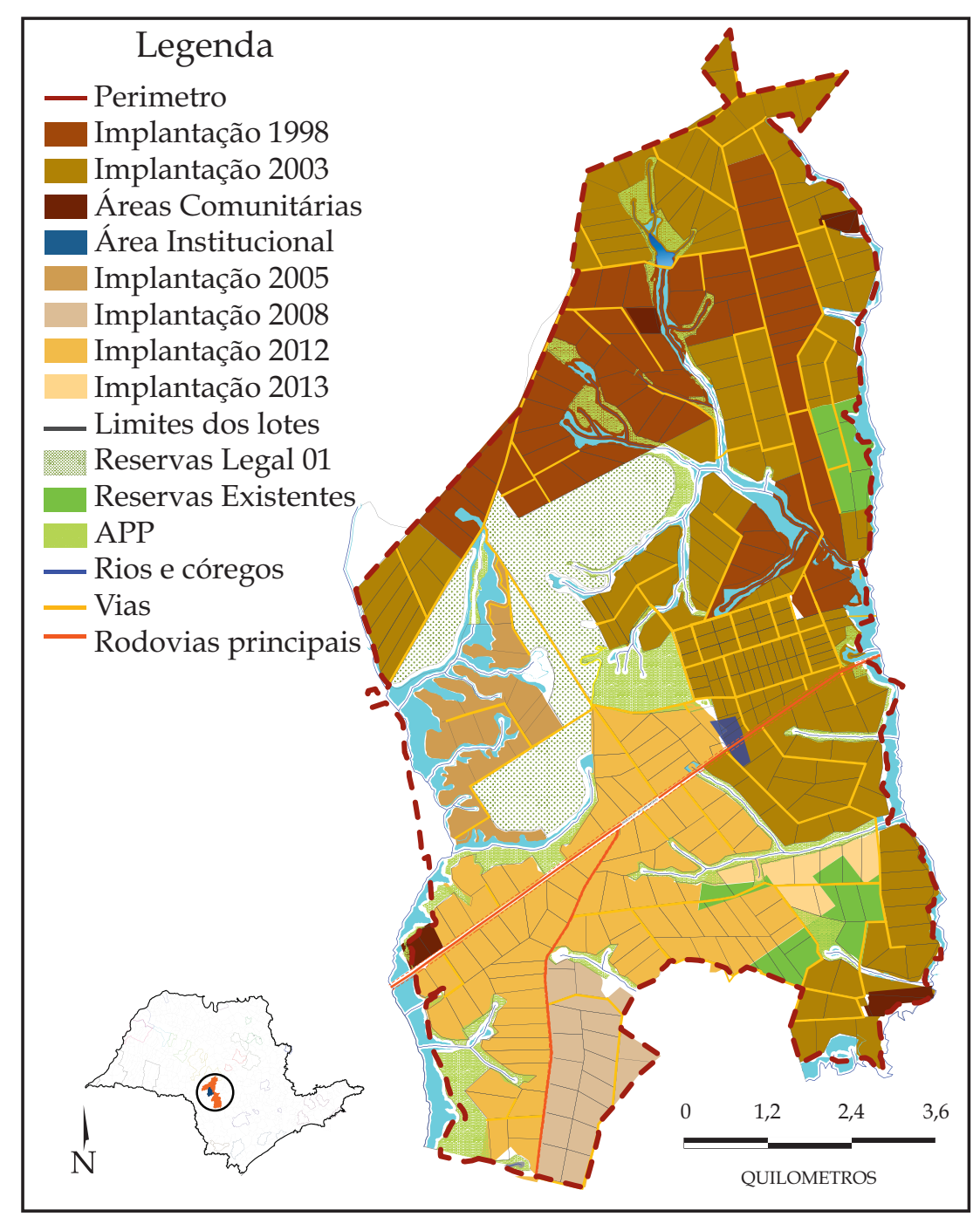

Figura 14: Síntese da evolução da ocupação

Fonte: elaborado pela autora, 2013. 
O roteiro que organizava as ações técnicas era norteado pelo princípio da participação daqueles que seriam seus beneficiários, como principais agentes do processo construtivo das casas, atuando em conjunto com os técnicos do INCRA com a supervisão dos técnicos da CEF com a responsabilidade de aprovação dos serviços executados para pagamento da parcela. Como exemplo da efetivação do sistema proposto, o roteiro apresentava o processo construtivo das casas dentro de um seringal, experiência realizada no Acre, região sudoeste da região Norte do país, em uma escola de adultos onde todos eram seringueiros. Situação diferente daquela observada nos assentamentos rurais paulistas, nos quais cada família tem uma origem e uma história de vida, com experiências e conhecimentos diversos, não podendo ser tratado como um perfil social homogêneo. Sobre técnicas construtivas, faz referência às tradicionais e também às alternativas para a construção das casas, e cita como procedimento necessário a consideração dos desejos e necessidades de cada família para a organização espacial do lote, a definição da locação da moradia no lote, e a organização dos espaços internos da casa.

Porém, na prática, os beneficiários, ao assinarem o contrato, receberam um projeto tipo de unidade habitacional, com área proporcional ao recurso aportado no contrato individual, que variava de acordo com a arrecadação municipal. O processo construtivo proposto pelo programa previa a atuação de uma assistência técnica - engenheiros ou arquitetos - para orientar a construção das casas, por meio de mutirão, processo construtivo resultante do esforço coletivo de um grupo capacitado, apoiado por segmentos técnicos somado à ajuda mútua, com autogestão, que é o processo de execução de obra com a contribuição, em horas trabalhadas, pelos próprios interessados. Vejamos, neste ponto, que ao elaborar o roteiro para operacionalizar o programa, não foi considerada a condição do cotidiano das famílias assentadas no lote, seu modo de trabalho e vida no assentamento.
${ }^{21}$ Superintendência Regional de São Paulo.

22 A resolução 460/2006 define as diretrizes para utilização dos recursos do FGTS, tem como meta direcionar recursos para famílias de baixa renda (até 5 s.m.). E necessária uma Entidade Organizadora, neste caso o INCRA, responsável por organizar o grupo de beneficiários e promover e/ou produzir as unidades habitacionais, rurais na modalidade de Aquisição de Material de Construção neste caso. 
Dividido em duas categorias - aquisição de material para casas novas, e a reforma das casas existentes - o programa disponibilizou cinco tipos de unidades habitacionais, com programas de necessidades que priorizam a organização do quarto, cozinha e sala da unidade. Foram previstas ampliações para os espaços, no sentido de disponibilizar a opção de adequação das condições dos moradores, bem como a mudança do perfil familiar - considerando, neste momento, a permanência dos filhos no lote depois de casarem.

Em visita realizada em abril de 2012 ao ITESP, a responsável pelo desenho dos assentamentos aponta como fator de maior preocupação a evasão dos jovens, observada por técnicos de campo. A razão deste movimento se justifica pelo acesso aos programas de transferência direta de renda do Governo Federal e pelas dificuldades enfrentadas pela família durante o processo de assentamento. O tema da juventude rural, aparece como tema de destaque no texto de acompanhamento e análise do desenvolvimento rural, realizado pelo Instituto de Pesquisa Econômica Aplicada (IPEA), em março de 2008, e confirma a observação dos técnicos sobre a evasão de jovens:

Por isso, a transferência de jovens para as cidades, mais do que parte do movimento demográfico geral do processo de urbanização das sociedades industrializadas contemporâneas, tem sido vista como um problema, na medida em que não só contribui para o "esvaziamento" do campo, mas também pressagia o fim do mundo rural. (IPEA, 2008).

Na apresentação do roteiro são demonstradas as evoluções do uso da casa, com a construção de varandas externas as diretrizes de operação indicam que a precariedade nas instalações elétrica deve ser objeto de reforma. O programa prevê como item fundamental para o cumprimento do contrato, a implantação de fossas sépticas em cada unidade, e também nas reformas, como medida de prevenção à contaminação do solo pelo uso de fossa negra. A implantação da fossa foi um ponto conflituoso na implantação do programa. A cultura dos moradores rurais é o uso da fossa negra, mas este tipo de fossa pode, com fa- 
cilidade, contaminar o solo e prejudicar as atividades agrícolas, além de colocar em risco a saúde das famílias.

Concomitante à implantação do programa de moradia rural, houve um programa para a provisão de fossas biodigestoras, realizado pela Empresa Brasileira de Pesquisa Agropecuária (EMBRAPA). Este modelo foi difícil de ser implementado, devido primeiramente ao fato da CEF não aprovar, e à resistência dos beneficiário por aspectos culturais: para que haja a fermentação, neste tipo de fossa, os usuários devem abdicar do uso de produtos como cloro e desinfetante na limpeza do vaso sanitário, além de abastecer a fossa, uma vez por mês, com esterco bovino fresco. Para solucionar o problema da fossa, instalação indispensável para a conclusão da obra, a equipe que coordenava o programa de moradia, em 2008, propôs a implantação de uma pequena usina de concreto para executar os anéis que seriam utilizados na execução das fossas, gerando trabalho e economia no custo de execução deste serviço. Naquele momento não houve interesse das partes envolvidas em organizar a parceria e viabilizar a proposta, razão pela qual os anéis de concreto foram comprados em fornecedores próximos ao assentamento.

As alterações no projeto original, verificadas em diversas vistorias, era o reflexo de que o tipo da unidade habitacional proposta pelo programa não atendia às necessidades individuais de cada família. Sem a devida orientação, na maioria das vezes, essas alterações comprometeram a conclusão da obra. Durante os trabalhos, e em reuniões da equipe, foi possível identificar as principais alterações observadas nas casas novas: aumento na dimensão dos cômodos; varanda em todos os lados da casa - para proteger do sol e para receber visitas - laje de cerâmica coberta por telha; revestimento cerâmico no piso da casa inteira; a cobertura de telha cerâmica em quatro águas (e não de duas) para prevenir o destelhamento da casa em dias de vento forte. 
Em algumas regiões, observou-se, ainda, a demanda por fogões a lenha, na área externa (assentamentos mais distantes dos municípios - dificuldade no abastecimento de gás). A decisão de alterar o projeto da casa implicava certa burocracia, e muitas vezes, atrasava o processo de medição por parte dos técnicos do INCRA e da CEF para a liberação do recurso, atrasando o cronograma estabelecido. Outro ponto crítico do processo de construção das casas foi que o contrato era individual, no entanto, a medição dos serviços e liberação dos recursos seria por grupos. A organização desses grupos de contratos, não considerou a proximidade entre os lotes de um mesmo grupo, mas seguiu a ordem de entrega de documentos na assinatura do contrato.

Quanto à organização das áreas internas das habitações rurais, a cozinha aparece considerada como convencional, no interior da casa, podendo ser integrada à sala, conhecida como "cozinha americana". Isso pode ser indicativo da influencia de hábitos urbanos, pois a chamada "cozinha caipira", tradicional das moradias rurais é externa e com fogão a lenha nos fundos da casa.

As dificuldades de construção das casas, durante a operação do programa, indicaram incongruências que implicaram gargalos que inviabilizam a conclusão do programa dentro do prazo, o que fez com que a maioria das famílias no AZUP tenham ficado com o $\mathrm{CPF}$ comprometido na hora de acessar novos recursos para as unidades habitacionais. $\mathrm{O}$ formato da operacionalização, os tipos de unidades habitacionais disponibilizadas e a forma de loteamento do assentamento implicaram contratempos. $\mathrm{O}$ tamanho da fazenda, o tamanho do lote e as vias de acesso, e a distância em relação à cidade onde ficava a loja de material de construção, demandaram um tempo extra de deslocamento, não foi previsto, por exemplo, no prazo do contrato. As distâncias a serem percorridas, seja de lote a lote, seja do lote à área comunitária ou do assentamento para a cidade - na maioria dos casos eram 
feitas a pé ou de ônibus.

Na cidade, a produção de unidades habitacionais desenvolvida por processos autogeridos de organização popular, seguida da autogestão mais organizada e assistida por profissionais, se consolida como alternativa para materializar as políticas públicas. Decorrente desses movimentos, surge uma iniciativa popular organizada que, em 1988, com o Programa Nacional de Mutirões Habitacionais, experimenta o formato de uso de recursos repassados pelo Fundo de Garantia por Tempo de Serviço - FGTS - para a CEF . Em 2002/2003 a CEF firma parceria com o INCRA e com a Companhia de Desenvolvimento Habitacional Urbano - CDHU, no âmbito estadual, para subsidiar a moradia rural em assentamentos de reforma agrária via ITESP.

As primeiras implantações de assentamentos registradas são de 1985 e apenas em 2003 é organizado um programa específico para a construção das casas nos assentamentos, incluindo execução de tratamento hidro-sanitário. Isso indica que a conquista da terra não significa a disposição de infraestrutura social - habitação, saúde, educação, transporte - e produtiva - terra fértil, assistência técnica - necessária para a reorganização do cotidiano das famílias nessa nova condição.

Embora na análise dos indicadores do primeiro e único Censo da Reforma Agrária ${ }^{23}$, seja possível identificar o perfil social das famílias assentadas até 1997, as informações não são suficientes para se possa fazer uma reflexão sobre os aspectos que compõem a moradia no assentamento. Os dados que se referem ao histórico ocupacional do chefe da família, antes do assentamento, indicam que a atividade predominante é a agricultura. Ainda que não apareçam atividades urbanas nesse período histórico, é possível perceber as contradições que se estabelecem na medida em que os hábitos urbanos permeiam o cotidiano das famí-
23 Convênio entre Incra e Crub - Conselho Regional das Universidades Brasileiras e Unb - Universidade nacional de Brasília/DF atividade de campo realizadas entre 1996 e 1997 em 26 Estados na época 1.647 assentamentos criados entre 1964 e 1996. 
lias, seja pela influência do conteúdo da televisão, seja pela cultura e pelos produtos adquiridos nos supermercados ou no comércio dos municípios próximos aos assentamentos.

No que se refere à avaliação das habitações, o Censo não qualifica nem as condições das moradias, nem a infraestrutura habitacional. Os aspectos referentes às técnicas construtivas apontam um quadro geral do país: indicam que, na região Sul, as casas em madeira são

Foto 2: Casa construída com recursos do PMR

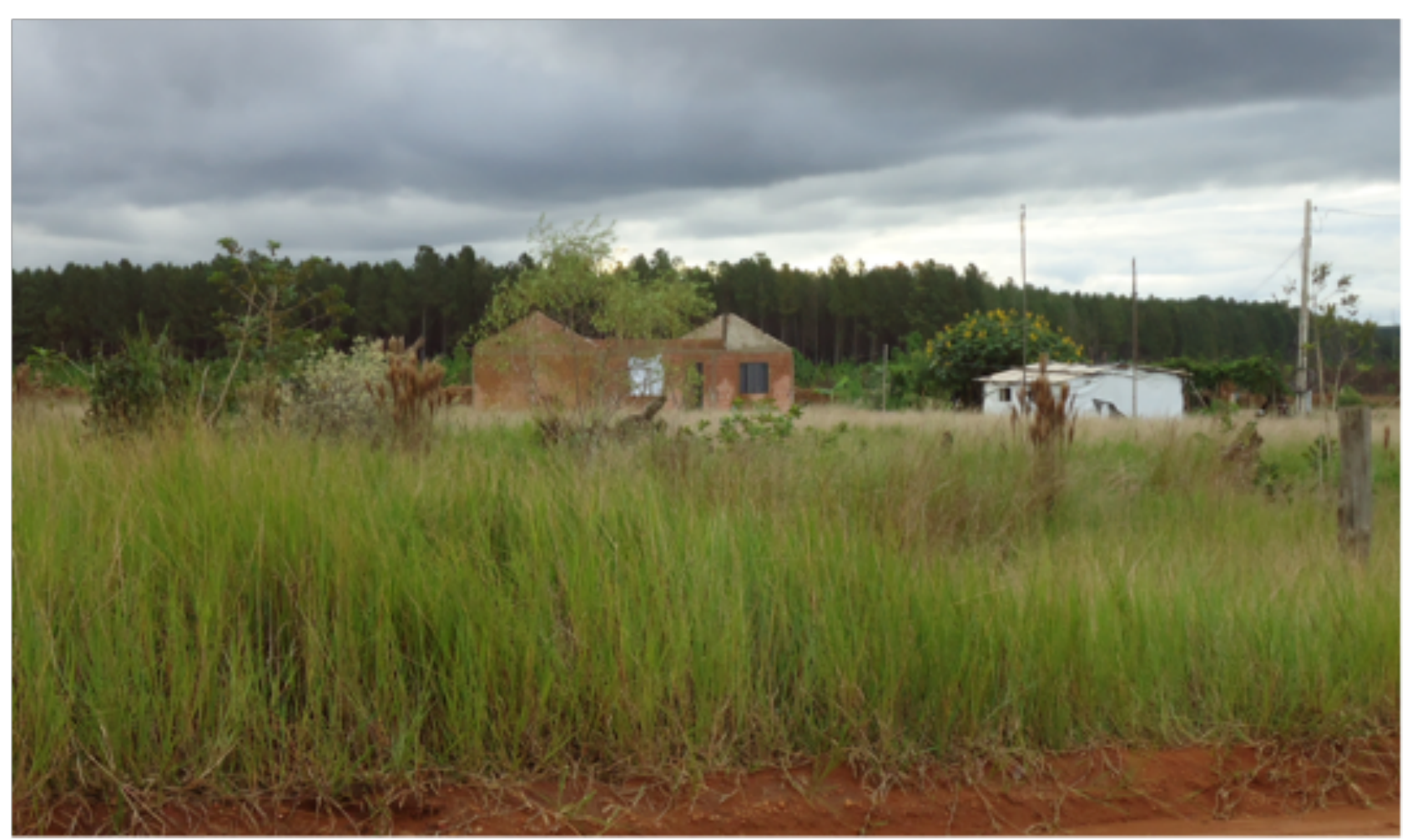

Fonte: foto registrada pela autora, 2013. 
predominantes, enquanto no sudeste a opção por alvenaria alcança quase $30 \%$ das unidades verificadas em 1997. Nota-se que o período do censo é anterior às políticas de habitação voltadas para o meio rural. A porcentagem baixa do indicador da condição de sua casa, associada à avaliação feita pelo morador, aponta um dado importante: 38,1\% consideram a casa regular e $25 \%$ reconhecem as condições precárias em que vivem, sugerindo, assim, um alto potencial de demanda habitacional nos assentamentos.

O Censo também não qualifica os assentamentos rurais em termos de infraestrutura, conexão com perímetro urbano mais próximo, e as condições de circulação nas estradas que dão acesso aos lotes, que são quesitos importantes para a viabilização do cotidiano das famílias assentadas. É possível apontar que os assentamentos são deficientes e, em sua maioria, carentes de programas habitacionais que contemplem não só a implantação da unidade habitacional, mas que considerem e definam a rede de infraestrutura necessária ao habitat rural.

Em São Paulo, os dados indicam um alto índice de coabitação familiar no meio rural: de um total de mais de 380 mil casas coabitadas ${ }^{24}$, quase 18 mil são rurais. Os dados da Fundação João Pinheiro - FJP sobre a inadequação da condição da moradia também indicam a demanda por ações focadas não só na regularização fundiária, mas também em novas moradias e construções mais adequadas, a fim de suprir a carência de infraestrutura (serviços básicos).
${ }^{24}$ Quando residem na mesma unidade habitacional mais de um núcleo familiar. 


\section{Capítulo 4}

\section{O ambiente construído no Zumbi dos Palmares}

Neste capítulo será apresentado o ambiente construído verificado no assentamento Zumbi dos Palmares a partir do levantamento de campo, organizado conforme descrito no capítulo anterior. Dando ênfase ao relato das pessoas com quem foi possível conversar durante a visita: são técnicos de campo, moradores ou líderes que representam as famílias. Organizado nas escalas de abordagem o capítulo registra os aspectos e as condicionantes do assentamento - aqui apresentadas por figuras, fotos, e relatos dos técnicos e de alguns moradores do assentamento - guiando a compreensão do ambiente construído. A sistematização desse levantamento, que revelou o ambiente construído no Zumbi dos Palmares, organizou, juntamente com as escalas de abordagem, critérios de análise que podem ser observados em todos os projetos.

A ocupação dos lotes no assentamento na área de uma fazenda transforma a situação fundiária; a propriedade de grandes extensões, por ser dividida em porções menores, possibilita a distribuição de terra e a instituição de um lugar projetado para responder a demandas de moradia e trabalho, não só de agricultores familiares, mas também de trabalhadores urbanos de origem rural. Nestes casos, o assentamento se apresenta como alternativa à superlotação urbana:

O projeto de assentamento como espaço de ressocialização é formado por um conjunto de ações técnicas que resultam na concepção do Projeto de Assentamento a partir da incorporação de um conteúdo novo no espaço abstrato. A construção do assentamento implica a construção do assentado. (MARQUES, M.I.M., 2000, p. 106). 
Como visto no segundo capítulo, o projeto de implantação de um assentamento rural no Estado de São Paulo segue normas e diretrizes técnicas elaboradas pelas instituições governamentais responsáveis pelo processo de criação. Para projetá-lo, os técnicos devem considerar as características do meio físico, benfeitorias existentes bem como o perfil do grupo que será beneficiário. No entanto o levantamento realizado indicou que a participação, as características do grupo, e as formas diferenciadas de parcelamento estão em segundo plano, exceto nos casos nos quais a organização social é representativa. Nesse caso, embora as experiências possam ser identificadas, elas não serão objeto de estudo desta pesquisa por se tratar de casos isolados no Estado. A adoção de princípios de racionalidade, objetividade e participação fazem
parte da metodologia sugerida para a condução dos projetos, no entanto,
na prática não são criadas condições institucionais e financeiras para uma
real estruturação dos assentados e seus sistemas produtivos, colocando em
risco os objetivos de produção e produtividade estabelecidos pelo Estado.
(MARQUES, M.I.M., 2000, p.107).

Já foi apontado, como objeto de estudo, no capítulo anterior, o assentamento Zumbi dos Palmares, localizado em Iaras. Este é um assentamento cuja criação foi orientada pelas políticas e atendido pelos programas do I e do II PNRA. Tendo sido implantado em etapas teve em seu parcelamento diferentes formas resultantes da forma de obtenção de terras, seu estudo permitiu a identificação das diferentes condições de cada etapa de implantação.

Neste capítulo, o assentamento será observado considerando os indicadores e as variáveis organizados nas escalas de abordagem para analisar a resultante do ambiente que se constrói com a ocupação dos lotes e o acesso aos recursos disponíveis para instalação da família.

A paisagem ${ }^{25}$ que se verifica quando se percorre o interior do Estado é uma extensa
25 Paisagem é entendida aqui como o resultado da materialização de relações sociais. Acredita-se, assim como Berque, que os valores de paisagem mudam com o tempo e com a cultura. A paisagem é algo criado e não dado - as relações sociais é que tecem a paisagem. É o modo de relação com o ambiente. Para o autor, a intencionalidade constitui uma paisagem. (BERQUE, 1994) 
zona rural ocupada por grandes propriedades, monoculturas que variam conforme a região. Nas proximidades de perímetros urbanos, nota-se a presença mais frequente de loteamentos fechados destinados a moradias de alto e médio padrão, indicando certa variação no uso do solo, no qual os assentamentos rurais aparecem em menor proporção. Por não constarem no planejamento municipal e pela falta de articulação entre as esferas estadual e federal, os assentamentos rurais aparecem como fragmentos que compõe o meio rural paulista desde 1985.

[...]a necessidade de executar obras de infraestrutura adaptadas às necessidades locais, a participação das prefeituras municipais e dos governos estaduais aparece como crucial: não se pode pensar em reforma agrária como uma instância de política unicamente federal. (GUANZIROLI apud MARTINS, 2010)

Localizados entre grandes propriedades, podem estar mais próximos das áreas urbanas do que das áreas rurais, como é o caso do assentamento Fazenda Guarani, localizado no município de Sandovalina, região do Pontal do Paranapanema. A situação que se verifica é que o perímetro urbano do município está cercado por lotes do assentamento.

Foi a partir dos anos 1990 que teve início a diversificação do uso do solo na interface rural-urbana das grandes cidades. A continuidade do crescimento estendida às cidades medias, em pouco tempo alcançou as pequenas, como Águas de Santa Bárbara na região central do Estado, implicando expansão da fronteira urbana sobre o rural.

O incentivo gerado por políticas de financiamento de habitação, como o programa Minha Casa Minha Vida, criado pelo Governo Federal em 2009, incentivou o crescimento da construção civil a partir da construção de novas unidades habitacionais. O reflexo desta ação tem sido o aumento do preço da terra urbana, dessa maneira os investidores encontram no perímetro rural mais imediato às cidades um alternativa para construção. 
Quando se estuda o contexto dos assentamentos rurais em São Paulo, pode-se observar que a distância entre o urbano e o rural muitas vezes ultrapassa a escala do cotidiano, principalmente porque a ida dos moradores do assentamento à cidade não é tão frequente, não faz parte de suas atividades diárias. Ainda assim, a relação entre as duas zonas é constante, por isso não é entendida aqui de forma isolada.

$\mathrm{Na}$ maioria das vezes, os assentamentos estão localizados entre grandes propriedades, mas também podem ser vizinhos das áreas urbanas, como é o caso do assentamento Fazenda Guarani em Sandovalina - Pontal do Paranapanema: o perímetro urbano do município está cercado por lotes do assentamento e não tem mais do que dois lotes do assentamento de área para crescer. Nesta região, assim como a região central do Estado, onde estão localizadas Águas de Santa Bárbara e Iaras, o uso do solo com assentamentos rurais é mais frequente do que nas outras regiões do Estado.

A elaboração do projeto de assentamento, nas diferentes escalas como visto nos dois pri-

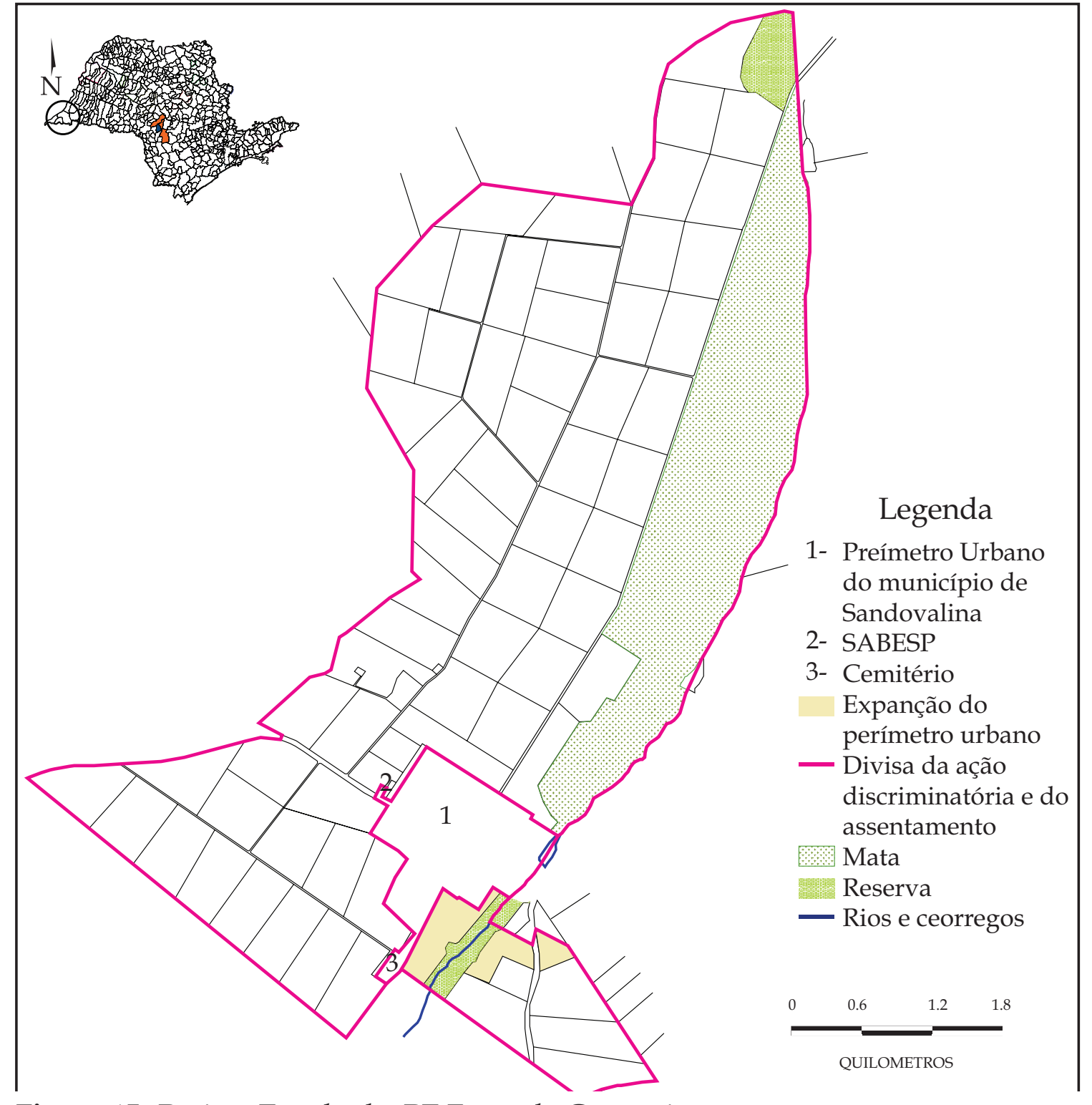

Figura 15: Projeto Estadual - PE Fazenda Guarani $\quad$ Fonte: ITESP, 2013 
meiros capítulos, pressupõe a participação do grupo que será assentado. No entanto, no levantamento realizado para identificar forma como o projeto se materializa, identificou-se que, assim como na maioria das implantações paulistas, o AZUP foi parcelado por técnicos que trouxeram os dados de campo - área, topografia, benfeitorias/vias - , e elaboram o anteprojeto do parcelamento, sem que houvesse participação das famílias na definição dos usos do solo, na forma de divisão de lotes, no traçado das estradas.

Os dados obtidos nesse levantamento de campo serviram como instrumento para qualificação ${ }^{26}$ do ambiente construído no Zumbi dos Palmares, e para que se verificassem os elementos compõe esse ambiente. Foi possível constatar que alguns assentamentos criados no âmbito estadual são atendidos por programas e projetos da entidade federal. A condição específica do cotidiano nos assentamentos rurais ultrapassa os procedimentos burocráticos da gestão de políticas públicas. Em sua pesquisa Marques (2000) aborda a fragilidade na criação e operação dos assentamentos rurais indicando que a fragilidade da operação é uma condição que extrapola os limites estaduais:

\section{A adoção de princípios de racionalidade, objetividade e participação fazem parte da metodologia sugerida para a condução dos projetos, no entanto, na prática não são criadas condições institucionais e financeiras para uma real estruturação dos assentados e seus sistemas produtivos, colocando em risco os objetivos de produção e produtividade estabelecidos pelo Estado. (MARQUES, M.I.M., 2000, p.107).}

A dinâmica no interior do assentamento entre as atividades do cotidiano da família e as ações que operam os programas das diferentes escalas de ação pública não são articuladas entre si e por isso, muitas vezes dificultam o caminho no sentido de viabilizar a emancipação das famílias. Em São Paulo, as primeiras implantações tem mais de 25 anos, e ainda não constam nos registros da autarquia federal representada no Estado até abril de 2012, nem no âmbito estadual assentamentos rurais emancipados, ou seja, assentamentos
26 Entende-se que a qualidade do ambiente construído está relacionado como define SAMORA (2009) na adequação do objeto construído às necessidades dos ocupantes quanto ao uso a que se destina e às especificidades do sítio onde está inserido. Ainda que a autora tenha tratado do projeto de habitação em favelas é possível associar a realidade dos assentamentos por também ter sido concebido, para atender especificidades das áreas nas diversas modalidades, assim como o projeto de reurbanização de favelas estudados pela autora. 
nos quais o conjunto de famílias tornou-se independente da ação governamental ou tenha quitado a dívida gerada na entrada da terra.

\subsection{Escala Macro: o assentamento e seus vizinhos}

O assentamento Zumbi dos Palmares está inserido na região central do Estado, formada pelos municípios de Iaras, Araraquara, Colômbia, Descalvado, Ribeirão Preto, São Carlos e Piratininga, caracterizada pelo dinamismo do agronegócio e pela presença de empresas sucroalcooleiras e madeireiras. Em suas notas metodológicas, a pesquisa INCRA/ UNIARA (2012), divide a grande região em microrregiões e caracteriza a região de Iaras, Ribeirão Preto e Piratininga pela presença do MST.

A pesquisa aborda o modelo produtivo estabelecido nos assentamentos desta região - como é o caso do AZUP -, e reconhece que o mesmo foi projetado nos moldes da agricultura tradicional, ligada ao agronegócio das cidades onde estão localizados. Muitas vezes, nesse envolvimento, como é o caso do assentamento Zumbi dos Palmares tratado como objeto de estudo, as terras do assentamento acabam parecendo extensão da própria empresa agrícola.

Para FERRANTE e BARONE (2012), a trajetória dessas experiências não se diferencia muito das demais, no restante do Estado de São Paulo, principalmente no que toca a ação dos órgãos públicos responsáveis. Os autores indicam, que a falta de planejamento, a desorganização de um cronograma racional de investimentos e o esvaziamento cíclico da 
estrutura de assistência técnica, prejudica o desenvolvimento das famílias assentadas. No entanto, em comparação com os assentamentos de outras regiões, a característica mais marcante da implantação do Zumbi dos Palmares, é sua inserção territorial, dada numa região de agricultura modernizada e monopolizada pelas culturas da cana-de-açúcar e de citros.

O complexo papeleiro que caracteriza o entrono do AZUP também influencia as atividades no assentamento. Nessa região, os assentamentos criados registram a presença de eucaliptos nos lotes, nas áreas comuns, além da produção de gado leiteiro. Os autores definem o AZUP como um assentamento em constante transformação. Por ter sido implantado em diferentes etapas, formou núcleos diferenciados pelo tempo de implantação, os mais antigos assentados sob as diretrizes do I PNRA e os mais novos amparados pelo II PNRA. Além dos lotes ocupados pelas famílias assentadas, existem áreas que estão ocupadas pelo MST, que reivindica o parcelamento de novos lotes.

A distância de São Paulo até o acesso a Iaras é de $285 \mathrm{~km}$ na rodovia BR374/SP-280 Castelo Branco. O acesso ao assentamento está do lado oposto à cidade, localizado no interior do município, entre grandes propriedades produtoras de cana, laranja e gado. Também pode ser acessado pela rodovia SP-261,Osni Mateus a 10,4km do acesso da cidade, no sentido de Lençóis Paulista. O entrono de Iaras é formado por cinco municípios: Bauru $(102 \mathrm{~km})$, Lençóis Paulista $(100 \mathrm{~km})$, Avaré $(62 \mathrm{~km})$, Águas de Santa Bárbara $(11 \mathrm{~km})$ e Botucatu $(100 \mathrm{~km})$. Caracterizada pela presença de assentamentos esta região tem se organizado pela presença dos escritórios regionais do INCRA e do ITESP que buscam operar de maneira mais presente com equipes de assistência técnica, em busca de melhora da qualidade de vida das famílias residentes.

A figura 16 mostra a inserção da escala macro definida pelo raio de 100km. 


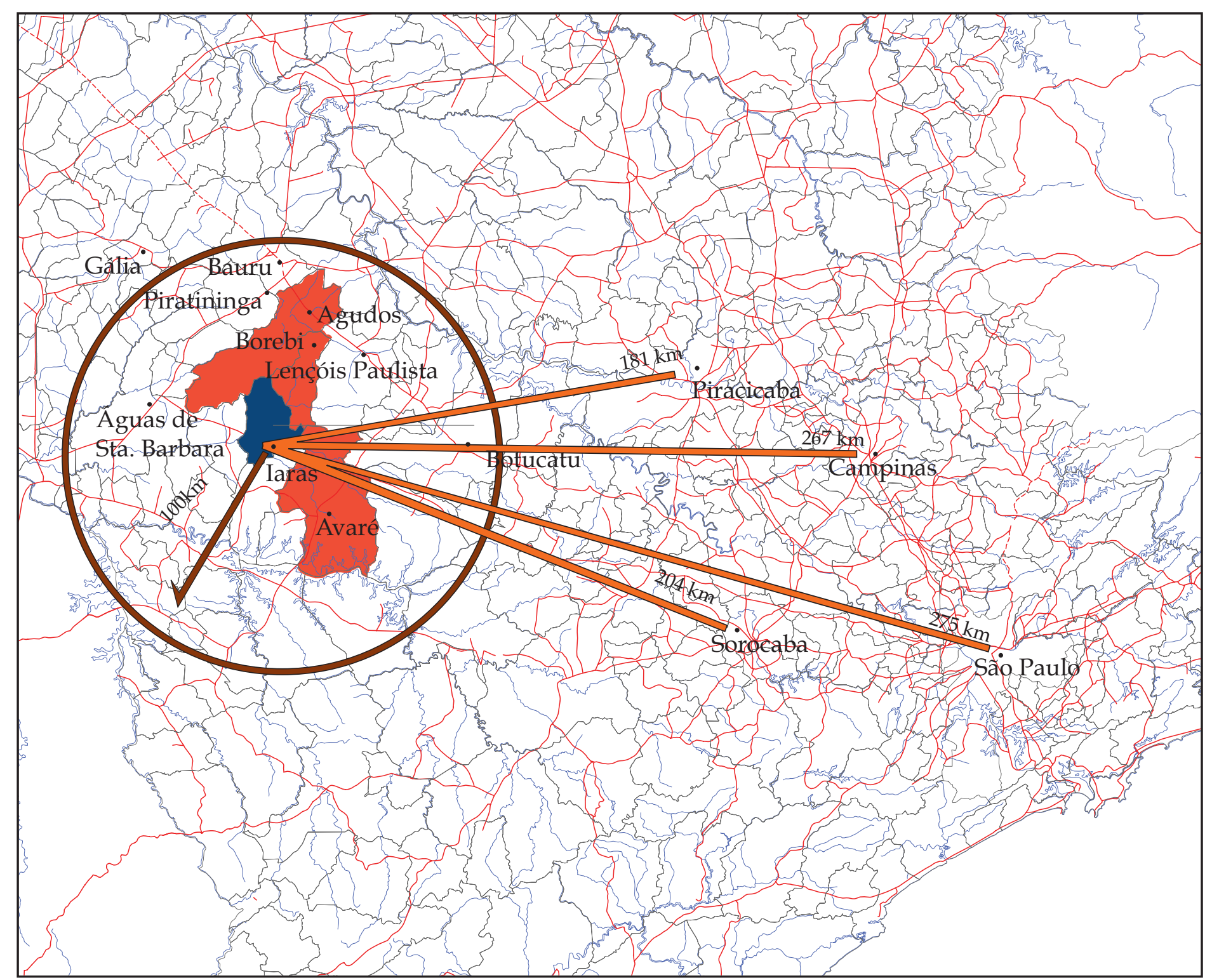

Figura 16: Entorno regional de Iaras - escala macro
Legenda

Municipio de Iaras

Região central

- Distância em linha reta

- Raio de 100Km

— Vias

— Rios e córregos
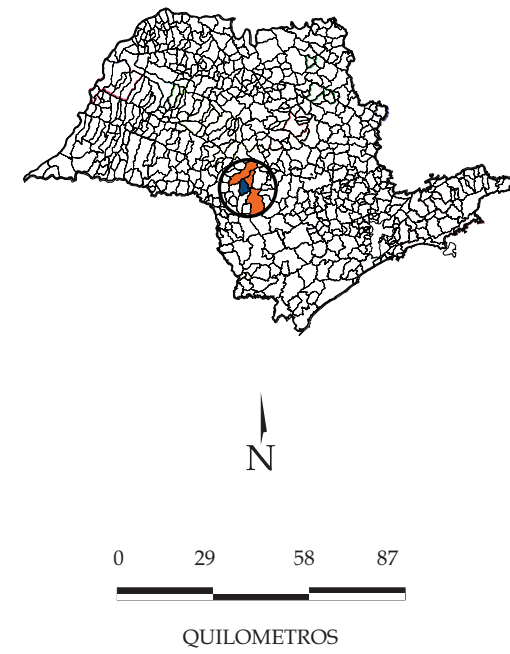

Fonte: elaborado pela autora, IBGE, 2013 
A distância entre o assentamento e a cidade é de 22,6km, esse deslocamento, na maioria das vezes, é feito de ônibus que passa três vezes por dia, mas, nos dias de chuva, é comum o encontrar quebrado no estradão, ou não acessar alguns pontos por falta de condições das vias que ficam alagadas.

Estes 20 quilômetros são de terra batida e é um grande problema para o deslocamento de pessoas e mercadorias (principalmente em períodos de chuvas). (ROMANO, 2009 p. 19)

O percurso do assentamento até a cidade, de carro, demora cerca de trinta e cinco minutos quando as estradas estão em boas condições, a pé o percurso dura cerca de três horas.

As cidades do entrono, integram a região central do Estado de São Paulo, reconhecida e identificada pelo INCRA e pelo ITESP, que atuam de forma próxima com os escritórios locais. Muitas vezes, as atividades desempenhadas pelas famílias - seja para produção, trabalho fora do lote, aquisição de insumos agrícolas, material para construção ou mesmo produtos nos supermercados locais - que vivem no assentamento, estão localizadas nessas cidades.

Os vizinhos da parte sul do assentamento são as terras da fazenda Capão Rico (União) pertencente ao conjunto de fazendas do NCM; do lado oeste estão as terras da fazenda Pompeu que são de propriedade particular; a noroeste estão as terras da fazenda São Domingos do Tupã; quase no extremo norte da área ocupada pelo assentamento, estão as terras da fazenda Tangará II e da Santa Lucia, as duas de propriedade privada. Essas são produtoras de cana, laranja e criam gado; outras, são áreas ocupadas por pequenos agricultores familiares, sítios e chácaras que as famílias da região mantêm para o lazer ou cultivo de alimentos.

No extremo norte do Zumbi dos Palmares estão as terras da fazenda Turvinho, pertencentes à União por serem remanescentes do NCM, incorporadas ao patrimônio da União 
em 1909, em uma disputa registradas nos autos de execução de sentença entre a Cia. Colonial São Paulo-Paraná e a Secretaria da Fazenda Nacional em disputa na justiça federal de São Paulo.

De acordo com a pesquisa de ROMANO (2009), em 1996 uma parte das fazendas do NCM estava ocupada por pinus do Instituto Florestal27; o restante estava arrendado para grupos privados como a Eucatex e a Duratex, também para o plantio de pinus. Nessa época, esses grupos controlavam cerca de $60 \%$ das áreas do NCM, com a prática da exploração florestal. De acordo com o autor, os outros $40 \%$ estavam sob domínio de políticos da região que utilizam a terra para a exploração agropecuária e florestal. Na figura 20 o assentamento e a cidade de Iaras.

Localizada na parte norte do NCM, fronteira com a fazenda capivara a Fazenda Turvinho é um exemplo dos conflitos gerados pela falta de controle fundiário por parte do Estado nos limites do assentamento Zumbi dos Palmares. No estudo da cadeia sucessória dominial dos imóveis rurais realizado pelo INCRA em 1994, foi identificado um conflito entre os limites de uma área de terra pública com uma área de terras privadas. A área total em questão, formada por dois imóveis escriturados com o mesmo nome - Turvinho -, é formada por uma propriedade da UNIÃO, remanescente do NCM e por outra, de propriedade particular da família Pinheiro Machado. Uma área da primeira fazenda, sofreu ação de usucapião em 1983. Entretanto, a imprecisão na descrição do imóvel gerou uma série de conflitos que foram identificados com a sobreposição dos descritos nos registros.

Atualmente a área é ocupada pela empresa Sucocítrico Cutrale, conhecida pela extensa produção de laranja, que depois de processada, é importada. É por conta de uma sucessão de transcrições imprecisas que em 2005, quando a empresa entrou com o pedido de
27 Em 1961, o governo estadual passou a utilizar uma área de 29 mil hectares para fins de reflorestamento. (TEIXEIRA, 1996 apud MATINS, 2010). 
Nessa época estava vigente o I PNRA. O laudo da vistoria descreveu ausência de atividade, o que determinou a desapropriação, dando início à criação do assentamento. Com o mesmo nome da fazenda, o projeto do parcelamento disponibilizou para cada família, três lotes. O lote da agrovila para construir a unidade habitacional e organizar os pequenos cultivos; o segundo lote, com maior quantidade de água disponível, deveria ser utilizado para fins pecuários, e o terceiro para fins agrícola. Nesse assentamento, vivem 29 famílias que trabalham com diversas atividades, porém a pecuária leiteira é predominante.

Localizados ao norte do assentamento Zumbi dos Palmares, foram criados pelo INCRA, outros dois assentamentos, implantados com as diretrizes do II PNRA. O primeiro está localizado em Agudos, nas terras da Fazenda Maracy. Tem aproximadamente mil hectares, foi criado em 2007, após ter sido considerada área improdutiva, tornando-se apta ao processo de desapropriação. A criação do projeto na Maracy assentou 48 famílias que trabalham predominantemente com a pecuária.

Na divisa entre Agudos e Borebi, o assentamento Loiva Lurdes foi criado em 2009 numa área de aproximadamente 950 hectares, ocupa um lugar que é resultante da somatória de duas áreas. Uma parte das terras é remanescente do NCM, assim como a área ocupada pelo Zumbi dos Palmares. A outra parte era de propriedade da empresa de papel e celulose LWARCEL, tendo sido, obtida através do acordo com o INCRA. Nele foram assentadas 50 famílias. 


\subsection{Escala Média: a cidade e o assentamento}

O assentamento Zumbi dos Palmares é o maior assentamento da região de Iaras, ocupando uma área total de 7.766,3245 hectares. Na cidade, a praça Monções é ponto de encontro dos moradores; é o centro da pequena cidade, organiza o traçado das quadras. Funcionando como rotatória, é onde está o comércio e os principais serviços que movimentam a pequena cidade. Além da presença do assentamento, Iaras é também reconhecida pela presença de uma penitenciária.

Na praça, localizam-se a prefeitura, com caixas eletrônicos, a Câmara Municipal, a igreja, a biblioteca municipal, um espaço coberto (quiosque) com mesas e bancos onde as pessoas se reúnem. Há também equipamentos de lazer para crianças e para pessoas idosas. Do centro podem ser vistos o supermercado que tem no seu interior um posto da Caixa Econômica Federal, a escola de Ensino Fundamental, com ginásio de esportes. Ainda no perímetro da praça estão os Correios, a base da Polícia Militar e a sede da Fundação ITESP. O escritório do INCRA está localizado na rua atrás dos Correios.

O escritório do INCRA em Iaras funciona com pessoal da área administrativa - na maioria das vezes servidores - e os técnicos de campo, mantidos atualmente, por um convênio de assistência técnica especializada entre o Instituto BioSistêmico (IBS) e o INCRA. A demanda por equipe para gerir a assistência técnica rural foi apresentada no

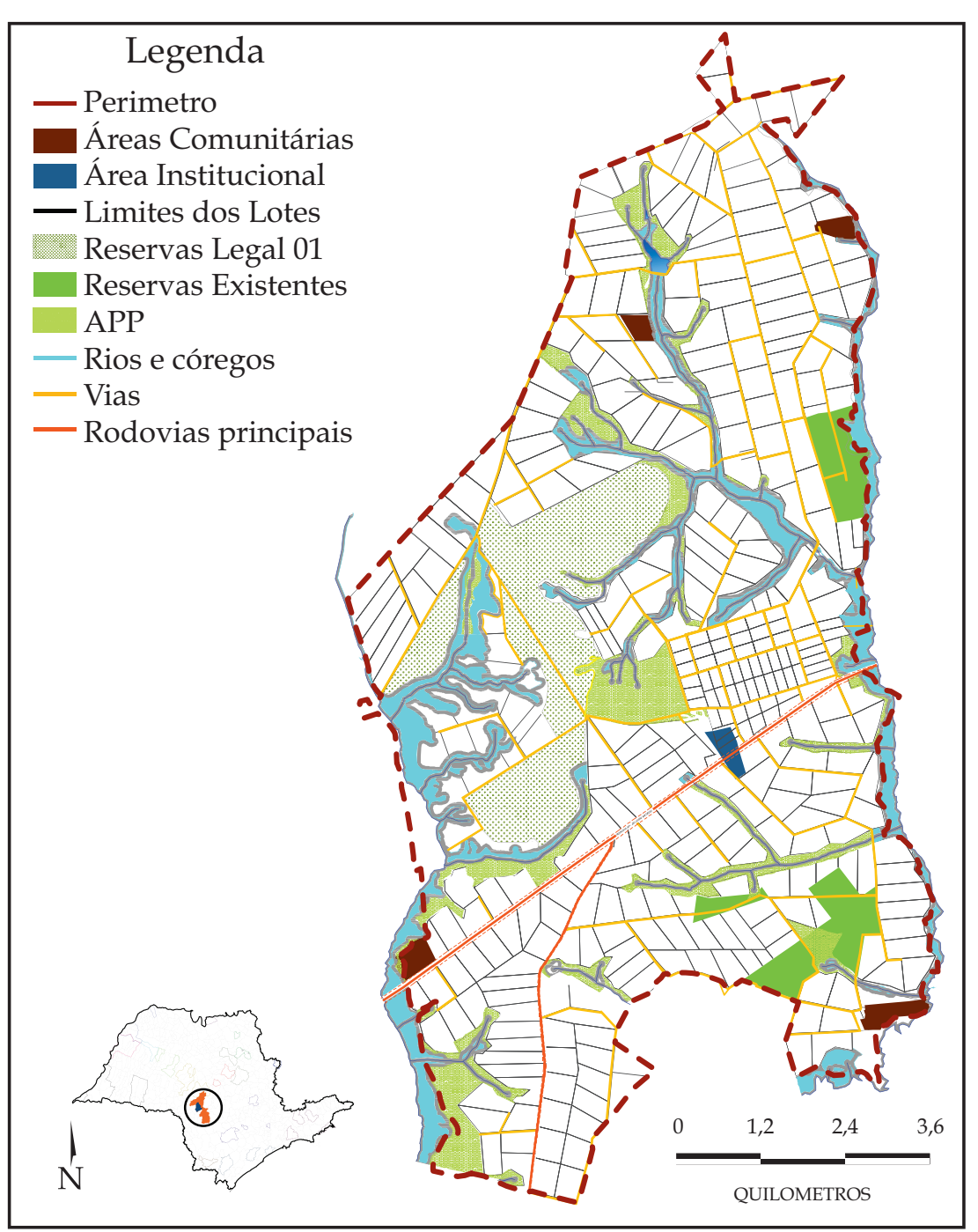

Figura 18: Projeto AZUP

Fonte: elaborado pela autora, 
manual de assistência técnica, que treina e orienta o trabalho dos técnicos de campo para atuarem no assentamento. Nese escritório, os técnicos de campo acompanharam as diferentes fases do assentamento e afirmaram que a seleção das famílias pode ser a causa do fracasso do assentamento, por serem elas "provenientes das cidades" (sic). Por outro lado, para alguns assentados, a vida, por mais precária que seja no lote, ainda é melhor do que a vida na periferia da cidade:

Contudo, apesar da precariedade da condição de vida
dos assentados, da falta de recursos e de infra-estruturas
os assentados se consideram em melhores condições de
vida antes do se tornarem assentados, mesmo não atingi-
do a linha da pobreza que se trata de “um indicar exóge-
no" (LEITE et al. apud ROMANO, 2009 p. 21).

O fluxo de pessoas no escritório é intenso; os moradores do assentamento vêm ao menos uma vez ao mês, pois não recebem suas correspondências em casa.

O assentamento não tem um endereço, não há nome de rua, nem número nas casas. No entanto, alguns lotes têm sua numeração indicada na entrada; outros recebem nomes de recantos, refúgios, sítios... Além da correspondência, os beneficiários procuram a sede do INCRA para resolver outros problemas, por exemplo, a prestação de contas da aquisição de insumos agrícolas ou da aquisição de material de construção dos diferentes créditos e subsídios contratados.

No levantamento realizado em 2013, o movimento intenso no escritório do INCRA foi registrado pela presença de assentados do Zum-
Foto 3: Perímetro urbano Iaras

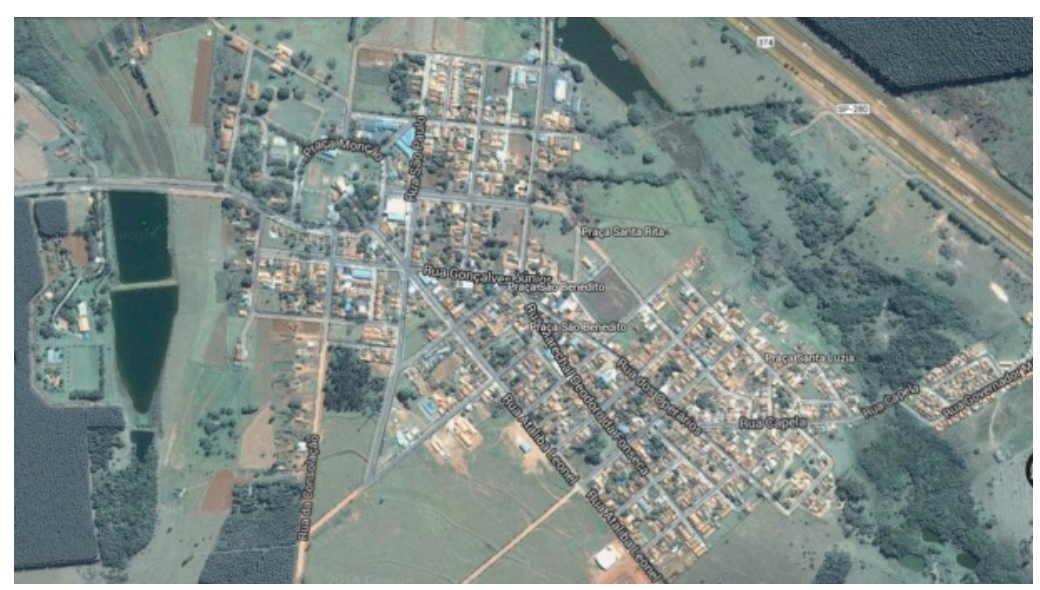

Fonte: Google Earth, 2013 
bi dos Palmares, que buscavam orientações para regularizar a condição do lote no qual foi implantado o barracão da associação. A reorganização das cooperativas e associações do assentamento foram também assuntos tratados. A retomada das atividades cooperativadas foi estimulada pela disponibilidade de créditos com os programas federais e estaduais de aquisição de alimentos. Outros assentados estavam preocupados com a seleção das próximas famílias. Seriam assentados 81 novos beneficiários entre outros que formariam uma lista de espera.

A entrada do assentamento é identificada na estrada por duas placas que informam os investimentos realizados pelo INCRA para instalação de poços artesianos.

\subsection{Escala Micro: do loteamento rural}

Esse assentamento, do tipo PA, teve como resultado da ocupação o parcelamento das áreas em momentos e condições que se diferenciaram em seu contexto. Cada uma das áreas pode ser caracterizada por sua forma: xadrez/espinha de peixe ou agrovila/pararrural. Os dias de chuva são críticos para os que moram no assentamento: as estradas de terra ficam encharcadas, alguns pontos ficam alagados, outros têm erosão ou atoleiros. Nesses dias, o ônibus que vai ao assentamento para levar as pessoas para a cidade quebra ou não consegue ultrapassar os pontos críticos,
Foto 4: Entrada do AZUP

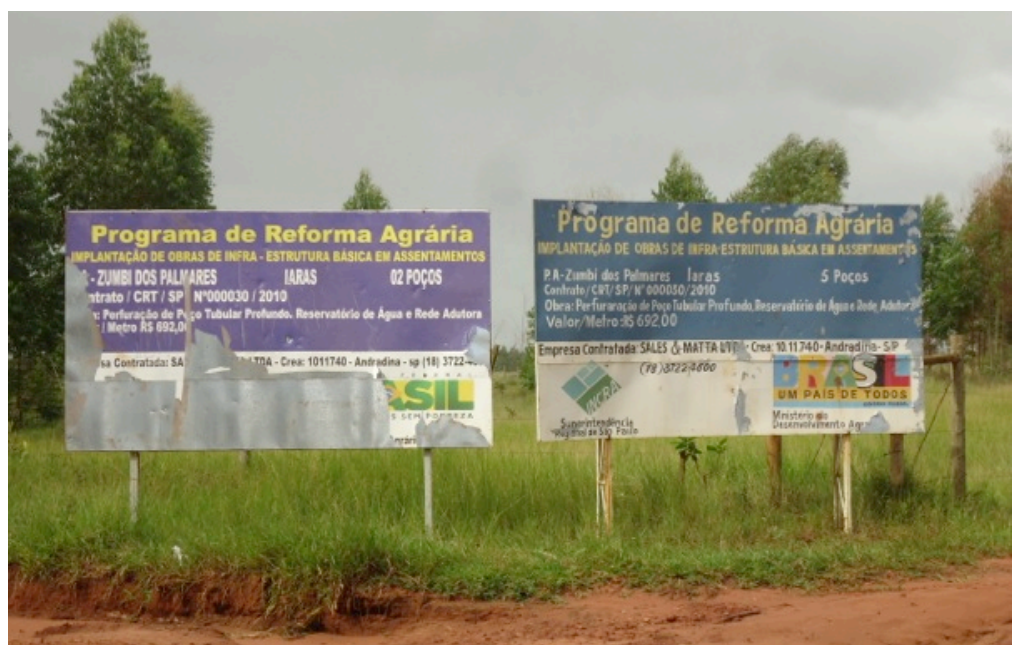

Fonte: foto registrada pela autora 
dificultando o trânsito das famílias.

O chamado estradão é a estrada municipal que sai da rodovia Castelo Branco - SP 280 e vai até a rodovia SP 261 - Osni Mateus que liga as cidades de Águas de Santa Bárbara à Lençóis Paulista. Depois de quase uma semana de chuvas não estava melhor do que algumas vias ou mesmo acesso aos lotes. Além disso, vale destacar que o assentamento foi implantado numa área entre dois rios; o lençol freático é alto, por isso alguns lugares ficam alagados. Outro fator que desestabiliza as estradas de terras é o trânsito de caminhões que transportam a cana produzida nas fazendas vizinhas ao assentamento para as usinas da região. Sem o ônibus, nos dias de chuva, os moradores do assentamento deslocam-se até a cidade a pé - o trajeto tem cerca de $20 \mathrm{~km}$.

Com 18 anos de trabalho no corte de cana, D. Neuza acredita que o trabalhador de origem rural sempre tem o sonho de ter a sua terra, mesmo que, para isso, tenha de enfrentar o sofrimento de acampar. Mesmo quando consegue a terra, tem de continuar lutando e enfrentando imensas dificuldades. Não cansa de repetir que a vida no assentamento é muito difícil, que tudo o que precisam para viver é muito difícil: "As pessoas ficam dez, 15 anos acampadas e quando consegue a terra não aguenta ficar". Ela ficou nove meses acampada numa das áreas do assentamento - a Anglo. Para ela, o assentamento é como uma favela rural.

Um estudo do Núcleo de Estudos Agrários e Desenvolvimento Rural - NEAD analisou assentamentos por todo o Brasil e constatou a precariedade de vida dos assentado. (LEITE et al. Apud ROMANO 2009).
Foto 5: Ônibus quebrado - Rod. Osni Mateus SP 261

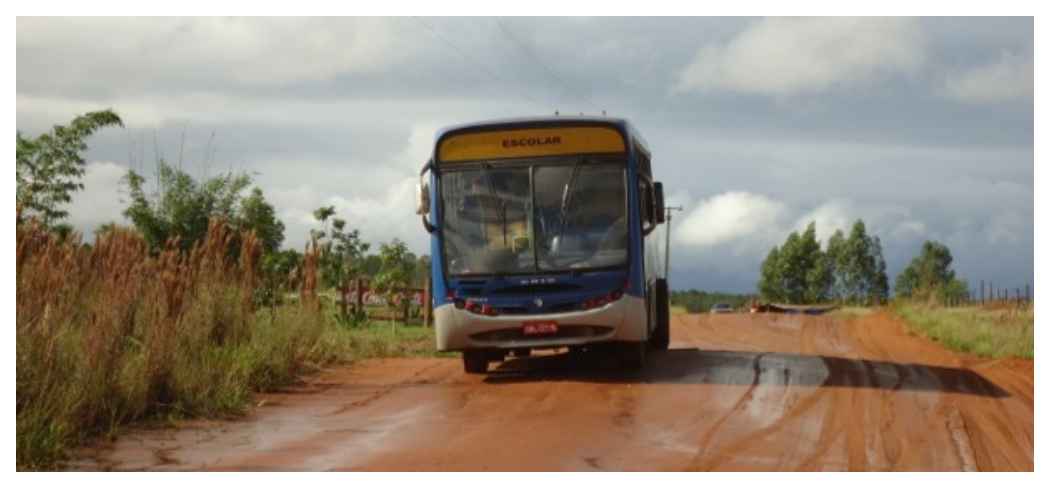

Fonte: foto registrada pela autora

Foto 6: Rod. Osni Mateus SP 261

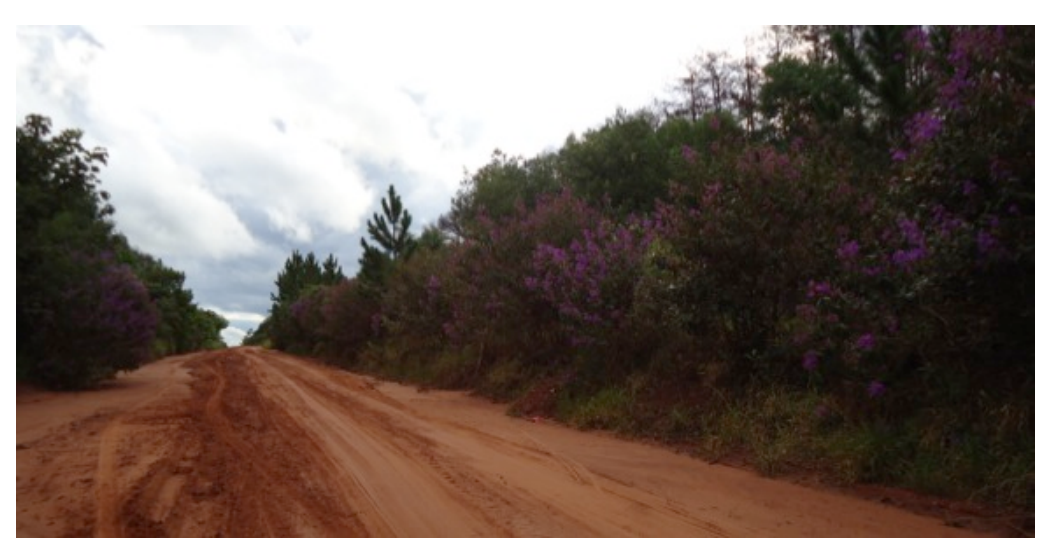

Fonte: foto registrada pela autora 
As famílias assentadas em 1998 fazem parte do primeiro grupo que ocupou o assentamento. Essas famílias tiveram acesso ao PRONAF; no entanto, foi em 2005 que receberam a visita de um engenheiro agrônomo e de um veterinário. Para dona Luzia, a falta de orientação e de técnicos resultou na perda de animais e insumos agrícolas. O segundo grupo de famílias assentadas e as demais, assentadas nas bases do II PNRA, tiveram oportunidade de, ao entrar no lote, acessar uma variedade maior de recursos disponibilizados em 2003. Puderam também contar com alguma orientação dos técnicos de campo, ação ampliada com a implantação do escritório em Iaras.

No assentamento, a Associação Rural Zumbi dos Palmares - ARZUP é responsável não só por recolher, com o trator do INCRA, as hortaliças produzidas nos lotes dos associados, como também por entregá-las na prefeitura de Iaras. São mais de 100 lotes que produzem para vender via associação. $O$ pagamento é feito via $C O N A B$ (superintendência de Bauru), que paga a nota da cooperativa com os recursos disponibilizados pelo Programa de Aquisição de Alimentos - PAA. Para dona Luzia, a sensação de abandono é o que faz muita gente ir embora, como se, ali, estivessem esquecidos.

O relato dos técnicos que atuam no assentamento indica que, desde 2010, o Zumbi dos Palmares tem sido marcado pelo aumento do índice de evasão. A constante entrada e saída das famílias agravou a incidência de informalidade e irregularidade nos lotes, aumentando os conflitos e as dificuldades de evolução do projeto.

O abandono e a venda de lotes são os conflitos comuns aos assentamentos paulistas. No mercado irregular de lotes vendidos no assenta- 

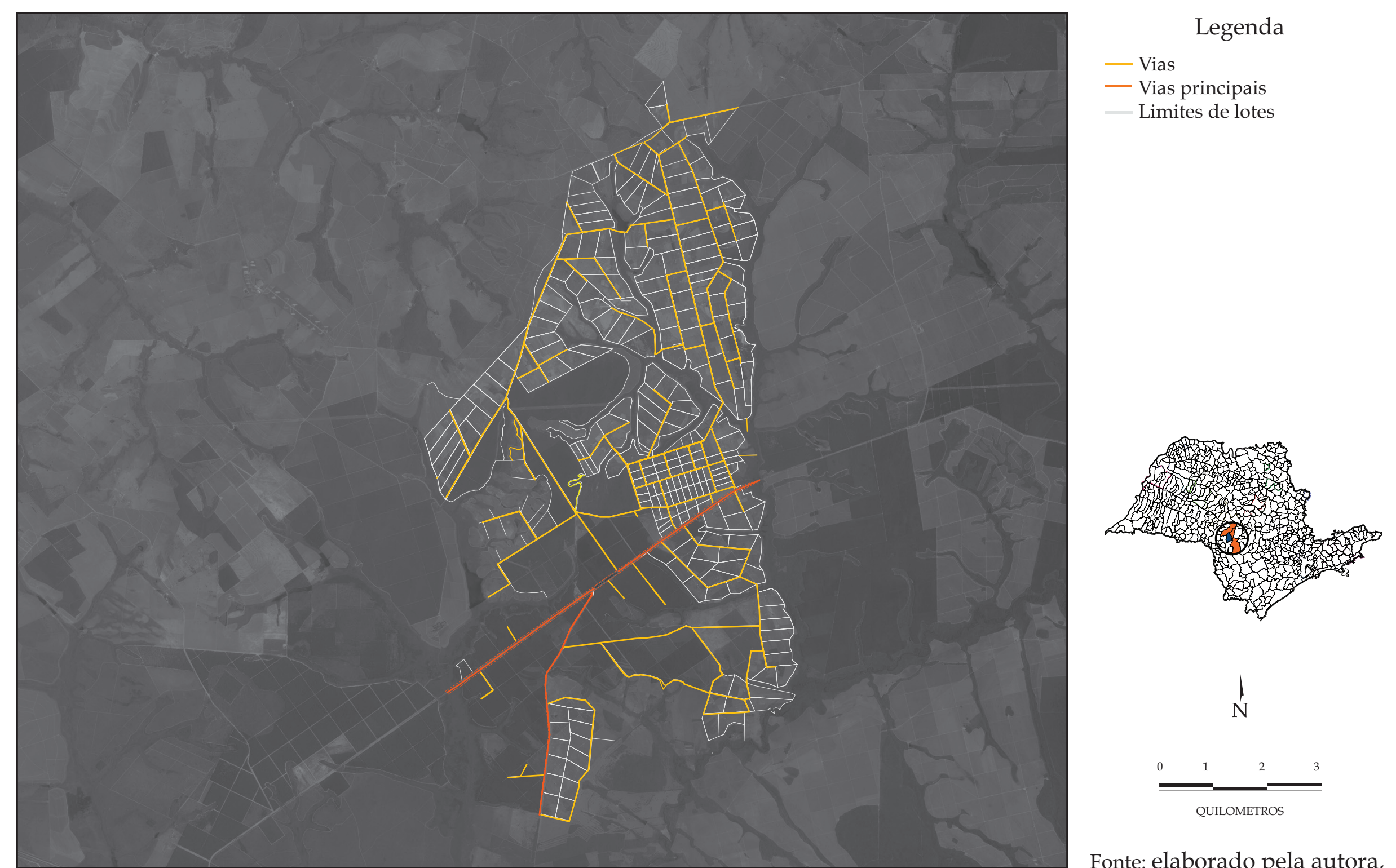

Figura 19: Assentamento Zumbi dos Palmares

Fonte: elaborado pela autora, INPE 2008 
mento, o para rural custa em torno de $\mathrm{R} \$ 5.000,00$, normalmente é comprado por famílias que vivem na cidade e querem ter um lugar para passar o final de semana, uma chácara, funcionários públicos no acampamento para ter lote.

Em São Paulo, além do PAA, existem outros dois programas destinados à aquisição da produção específica dos assentamentos. O governo do Estado, via ITESP, disponibiliza o Programa Paulista da Agricultura de Interesse Social (PPAIS), o qual disponibiliza R\$ 20 mil/ano/beneficiário e o Programa Nacional de Alimentação Escolar ${ }^{28}$ (PNAE) que adquire a produção no valor de até $\mathrm{R} \$ 12 \mathrm{mil} / \mathrm{ano}$.

No assentamento Zumbi dos Palmares não há uma forma de comercializa-
ção da produção que se destaque, as famílias utilizam diferentes canais, en-
tretanto, mesmo não sendo frequente, pelo menos periodicamente vão às
cidades e vendem aos supermercados. Alguns produtores vendem café,
leite, etc. à pequenas empresas que vão ao assentamento buscar a produção,
entretanto é um numero pequeno de produtores. (ROMANO, 2009 p.18).

Dona Neuza tem uma horta de $50 \mathrm{~m}^{2}$, uma parte de pasto, outra de eucalipto, um pomar, e vende a sua produção através do Programa de Aquisição de Alimentos - PAA. Recebe até $\mathrm{R} \$ 4.200,00 /$ ano. Caso tenha produzido mais do que isso deve recorrer à outra forma de escoamento.

Entretanto, a burocracia e as exigências não são factíveis e inviabilizam a contratação. Por exemplo: exigir frutas como uva e maçã, que dependem de condições climáticas específicas para serem produzidas. Se o produtor não tiver toda a variedade, não pode acessar o recurso. Outra dificuldade, já abordada anteriormente, é a falta da Licença Ambiental. Para D. Neuza, atualmente esse é o principal obstáculo para o desenvolvimento e a fixação das famílias.

A questão ambiental, que teve origem na fase do acampamento, é um dos principais
Lei no. 11.947/2009 - Destina 30\% dos recursos repassados pelo Fundo Nacional de Desenvolvimento da Educação para alimentação escolar na compra de produtos da agricultura familiar e suas organizações, priorizando os assentamentos de reforma agrária, comunidades tradicionais e quilombolas. 
aspectos que caracterizam a problemática do ambiente construído no assentamento. Constituído em 20 de Novembro de 1995, centenário de morte de Zumbi dos Palmares, o acampamento foi organizado por cerca de sessenta famílias, vindas de diversas regiões do Estado de São Paulo. Organizadas pelo Movimento dos Trabalhadores Rurais Sem Terra (MST), ocuparam 2400 hectares da Fazenda Capivara. Os trabalhadores acamparam na área usada pelo Instituto Florestal, cedida conforme determinação do Governo Federal. Este foi o primeiro passo para que as terras públicas da região fossem objetos da Reforma Agrária. (SOUZA, 2007).

Durante os dois anos seguintes, foram registradas diversas ocupações, e ao final, as famílias migraram o acampamento para as margens da Rodovia SP 261, que liga Águas de Santa Bárbara a Lençóis Paulista.

Com a primeira etapa do assentamento implantada, outros acampamentos chegaram ao município de Iaras, sendo o Madre Cristina, em 1998, e o Nova Canudos em 1999. Este último tem início com 1400 famílias.

Por terem sido - ambos organizados em áreas próximas aos ribeirões, e sem infraestrutura, deram origem ao problema ambiental do assentamento: a contaminação do solo e das águas, inviabilizando o licenciamento ambiental prejudicando
Foto 7: Primeiro acampamento na Fazenda Capivara - Rodovia SP 261 e plantação de eucaliptos, 1995.

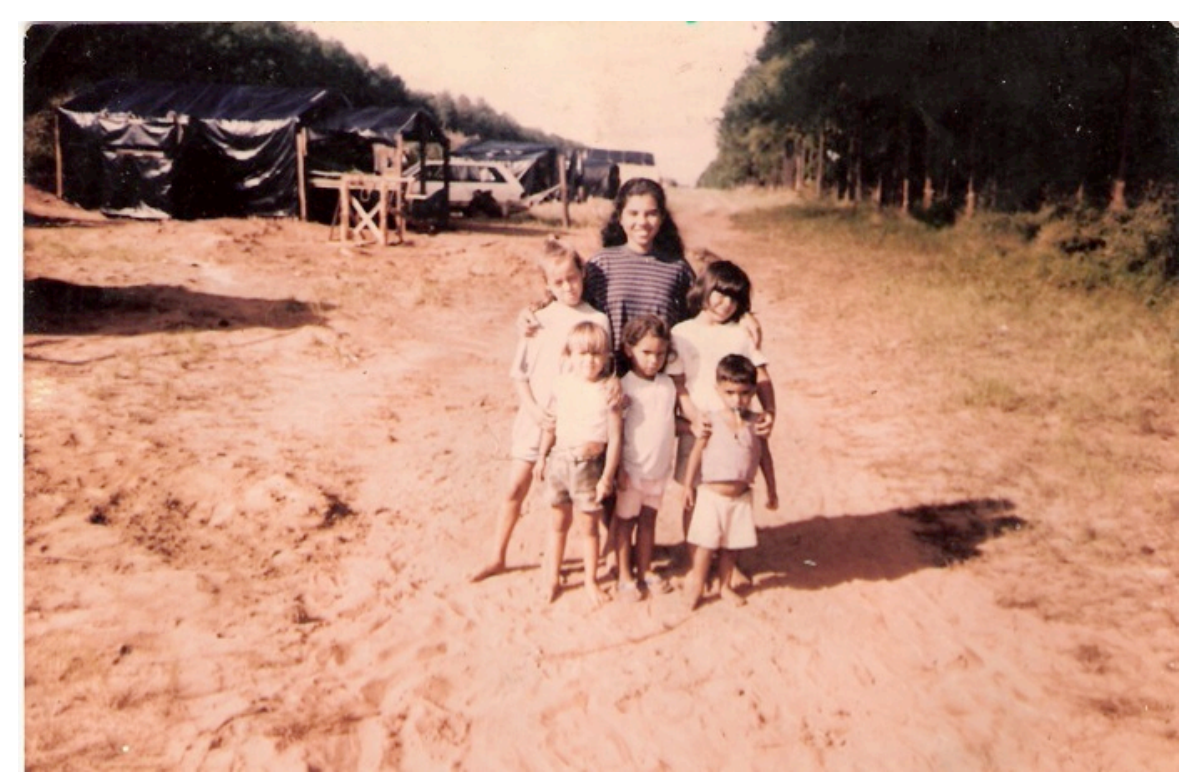

Fonte: SOUZA, 2007 
o desenvolvimento das famílias.

No projeto do parcelamento há indicações de áreas destinadas à Reserva Legal (RL) e de Preservação Permanente (APP): no entanto não existem, ou até então não foram reconhecidas, pois o assentamento não tem Licença Ambiental (LA). Esse é um dos problemas que as associações e as cooperativas do assentamento enfrentam.

No levantamento de campo, foram relatados casos de lotes que deveriam ter demarcadas e protegidas suas áreas de reserva legal e de preservação permanente, conforme consta no projeto, porém não é o que se verifica: algumas famílias não o fizeram ainda e a justificativa tem sido não conseguir administrar os recursos disponibilizados.

Sem a licença ambientala, não é possível acessar os recursos de programas e projetos, como o programa estadual de Bacia Hidrográfica, que disponibiliza recursos para recuperação das áreas de preservação permanente nos rios e ribeirões, entre outros programas que oferecem créditos e subsídios na tentativa de fixar as famílias.

As fazendas do entorno do assentamento, são produtoras de cana, eucalipto e laranja em grande escala, com uso de agrotóxicos. Cerca de cinquenta lotes do AZUP adquiriram como sistema de tratamento hidro sanitário, fossas biodigesto-
Foto 8: Acampamento na Rodovia SP 261 e a plantação de eucaliptos, 1996.

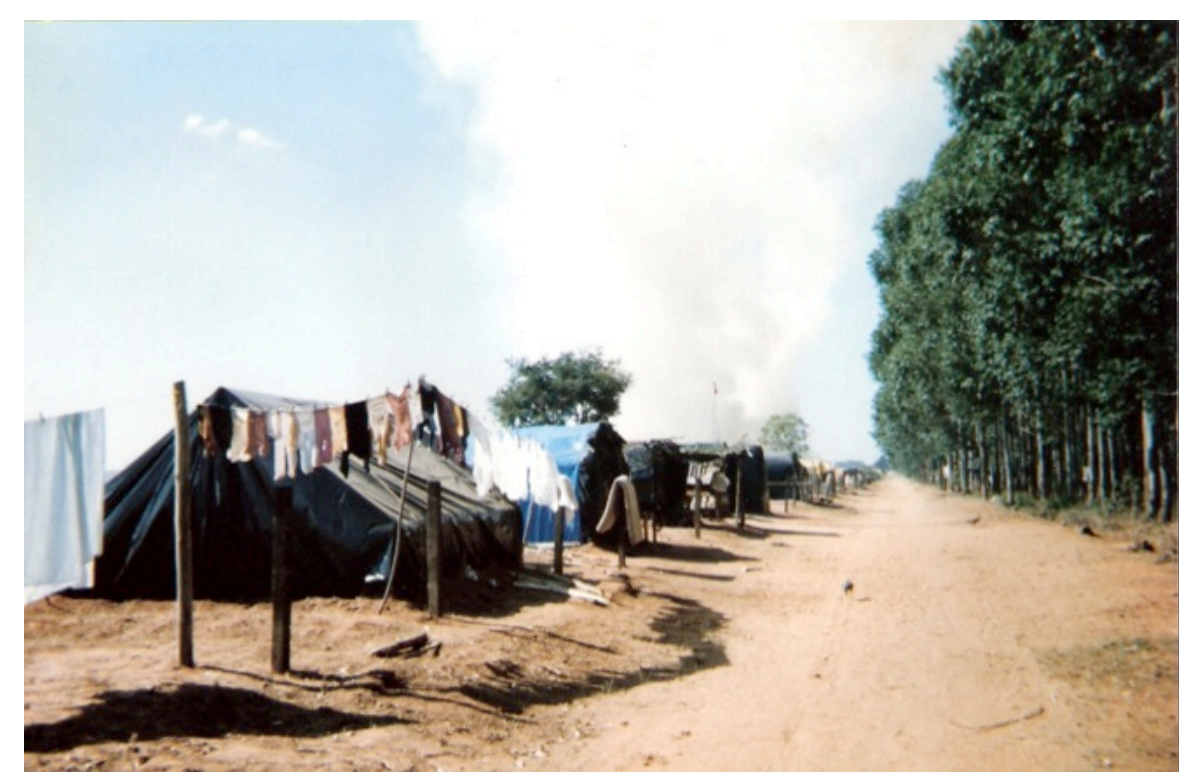

Fonte: SOUZA, 2007. 
ras, oferecidas pela EMBRAPA . Outros dez lotes construíram suas fossas com tubos de concreto, conforme projeto oferecido e demonstrado pela equipe de moradia em 2008. D. Neuza, usuária da fossa biodigestora reclamou do cheiro da água tratada, demonstrando preocupação com o seu esvaziamento. Na casa, moram ela, o marido e três filhos (dois homens: 25 e 18 anos; e uma moça de 19) que ajudam nos cuidados com o lote. Os meninos gostam de morar no assentamento, mas sentem falta de um projeto de vida para que sigam ali.

Nos relatos são apontados casos de consumo de drogas, principalmente pelas pessoas que vem de fora, que compram lote de forma irregular.

\subsubsection{Produção: cooperativas e associações}

No AZUP, a dimensão da fazenda e o alcance de vizinhança, obrigaram os assentados a se organizarem em grupos: Anglo (extremo norte do assentamento), Laranja, Globo, Carlos Lamarca, Lagoa da Traíra, Madre Cristina, Canudos, Camada, São Cristovam, Mutuca. Desses nove grupos, cinco estão organizados em cooperativas ou associações, das quais a pesquisa identificou duas: a Cooperativa de Produção Diversificada de Alimentos de Iaras - (COODAPAI) - criada em 2009 pelos assentados na área da Globo - e a Associação Rural do Zumbi dos Palmares - (ARZUP) produzem hortaliças. Algumas famílias produzem leite para um laticínio de Bauru.

Durante o trabalho de campo, pôde-se notar que, nos lotes, há sempre: uma área de
Tabela 8: Projeto de Assentamento Zumbi dos Palmares

\begin{tabular}{|l|r|}
\hline \multicolumn{2}{|c|}{ Assentamento Zumbi dos Palmares } \\
\hline Município & \multicolumn{1}{l|}{ laras } \\
\hline Projeto de Assentamento & PA - INCRA \\
\hline Criação & \multicolumn{1}{|l|}{ l998 } \\
\hline Data: & abril/2011 \\
\hline \multicolumn{2}{|c|}{ QUADRO DE ÁREAS } \\
\hline USO PROJETADO & ÁREA (ha) \\
\hline Área Agrícola - 377 lotes & $2,327.07$ \\
\hline Reserva Florestal + APP & $1,728.43$ \\
\hline Área Comunitária & 33.49 \\
\hline Institucional (escola e posto de saude) & 12.75 \\
\hline Área de eucalipto & $5,385.40$ \\
\hline Área total do Assentamento & $7,766.32$ \\
\hline
\end{tabular}

Fonte: INCRA, 2013 adaptado pela autora. 
pasto, e uma horta na qual as famílias produzem para o consumo próprio. Em diferentes conversas com assentados, quando o assunto abordado era a produção em grupo por meio das associações e cooperativas, foi relatado que alguns beneficiários tiveram essa experiência marcada por duas situações críticas. Nos dois casos, os problemas estavam relacionados ao uso de recursos acessados sem autorização do associado, o que acarretou em dívidas e prejuízos para muitas famílias e fragilizando a organização social.

A cooperativa era presidida por um líder do MST que morava no assentamento. Enquanto ele viveu ali, pôde manter certo controle sobre as famílias que viviam no assentamento. Sua presença evitava a entrada de pessoas irregulares, a venda e a compra de lotes abandonados.

A pesquisa UNIARA/INCRA (2012) revela que, no AZUP praticamente todos os assentados entrevistados, mostram desanimo com a situação do assentamento. Fazem referência ao problema com uma das cooperativas - Cooperativa de Comercialização e Prestação de Serviços dos Assentados da Reforma Agrária de Iaras e Região (COCAFI) -, que, em parceria com o INCRA, prometeu a reversão do dinheiro obtido com a extração da madeira existente na área, para o assentamento:

Recentemente o INCRA comprou do Estado de São Paulo parte das terras administradas pelo Instituto Florestal e está comercializando a madeira dos pinus através da cooperativa dos assentados no Zumbi dos Palmares. A cooperativa contratou uma empresa que está extraindo e que comprou a madeira. Os lucros deste processo serão convertidos no próprio assentamento coordenados pela cooperativa em conjunto com o INCRA. A área do Instituto Florestal será destinada para assentamento do MST. (ROMANO, 2009)

Na época, foram discutidos projetos de benfeitorias para o assentamento, entre eles, a construção de um lacticínio. Entretanto a madeira foi retirada do assentamento e nenhuma benfeitoria de grande porte foi feita. O dinheiro revertido foi suficiente para implantação 
de dois tanques de resfriamento de leite, aquisição de ordenhadeiras mecânicas, alguns kits para horta e dois tratores para a cooperativa, mas isso estava muito aquém do que havia sido tratado nas discussões em assembleias com as famílias associadas.

Diante das dificuldades encontradas, tanto no momento da entrada, quanto durante a fixação das famílias, muitos assentados do AZUP passaram a trabalhar fora do assentamento, principalmente para a Cutrale, que tem sua plantação de laranja vizinha ao assentamento. A empresa, para atrair os trabalhadores, disponibiliza transporte coletivo da plantação ao assentamento, ou seja, facilita a opção de trabalho. Registrados, os assentados vivem com um salário, que garantido ao final do mês, assegura o pagamento das contas. Quando isso acontece, o reflexo pode ser visto no lote, que, sem cuidados, vai ganhando aspecto de abandono.

Cerca de 70\% do pessoal que mora no assentamento trabalha fora, pois não consegue viver do lote. Passam no assentamento cinco ônibus para levar os trabalhadores à fazenda da Cutrale. Há também aqueles que vão para as fazendas vizinhas, para as granjas, ou para as cidades vizinhas trabalhar como pedreiro. Estes chegam a ganhar de R $\$ 800$ a R $\$ 900 /$ mês com registro na carteira. No geral, o assentamento produz mandioca/gado/leite/chuchu/ pouco milho.

Os sistemas de produção nos Projetos de Assentamento são muito semel-
hantes aos da agricultura familiar. É claro que não são todos os assentados
que conseguem rapidamente crescer na terra, e alguns até desistem de suas
áreas. Isto ocorre por falhas na seleção dos beneficiários (sem perfil e/ou
aptidão agrícola) ou na escolha das terras onde se implantarão os Projetos
de Assentamento (pouca fertilidade, estrutura do solo, dificuldade de es-
coamento de produção, etc.(GUANZIROLI apud MARTINS, 2010).

Pesquisador do projeto de Cooperação Técnica INCRA/FAO, sobre o desenvolvimento dos assentamentos de reforma agrária, Guanziroli afirma que os beneficiários do 
AZUP têm muitos problemas no que diz respeito à assistência técnica, pois, de acordo com o perfil das famílias, verificado no levantamento de campo, cerca de $70 \%$ são de origem urbana. Por isso, se faz-se necessário um acompanhamento mais intensivo por parte dos técnicos de campo. O trabalho de acompanhamento das famílias nos lotes, exige muito conhecimento técnico para uma argumentação convincente que esclareça os beneficiários. A maioria deles não conhece a realidade do meio rural. Chegam ao assentamento achando que estão chegando ao paraíso.

\subsubsection{Habitantes e habitação}

No meio rural, pode-se dizer que o uso da habitação transcende os limites da "casa". É mais pertinente concebe-la em relação ao uso da área na qual está inserida. Assim como PERES (2003), considera-se que a habitação é o reflexo do modo de vida da população, sua implantação, sua forma, seus materiais bem como a distribuição dos ambientes além de considerar a composição da família e o tipo de trabalho que desempenham.

O uso da habitação no assentamento transcende os limites da unidade habitacional: a casa é a marca concreta da ocupação permanente da terra pelo homem (KELLER apud PERES, 2003 p.89). Para o morador do assentamento rural ela é um elemento indispensável de trabalho, pois está ligada à terra e é nela que se constitui e se desenvolve a família. (ibid. p.92).

A substituição do barraco de lona por uma unidade habitacional adequada às con- 
dições de vida no assentamento é uma etapa esperada desde a entrada no lote; consolida o habitat rural no assentamento. $\mathrm{O}$ acesso às novas condições de moradia é fator de melhoria na qualidade de vida pois tem impacto nas dinâmicas de desenvolvimento rural, inclusive nos assentamentos (ROVER, 2006). A qualidade do ambiente construído deriva do que se considera moradia adequada: atende às demandas básicas: necessidades de uso, área, acesso, água, energia elétrica, esgotamento sanitário, área de lazer e estar.

O INCRA tem em seus registros as informações referentes ao lote e às benfeitorias que nele foram realizadas. No entanto, a contratação dos créditos por ser feita em nome e CPF do beneficiário, faz com que, no caso dele não cumprir com os compromissos assumidos, as eventuais dívidas e prejuízos ficam sob sua responsabilidade. Esse beneficiário inadimplente fará parte do Cadastro Nacional de Mutuários (CADMUT), administrado pela CEF, inviabilizado o acesso a outros recursos disponíveis por meio dos programas públicos.

As famílias assentadas na primeira etapa do assentamento, em 1998, acessaram, além do PRONAF, os recursos disponibilizados via banco do Brasil como o crédito instalação para aquisição de material de construção. As famílias assentadas a partir de 2005, além desses créditos, tiveram acesso aos recursos do Programa de Moradia Rural (PMR) - experiência pioneira na provisão de recursos para construção de habitações nos assentamentos paulistas. As famílias assentadas a partir de 2009, não tiveram acesso ao PMR devido ao insucesso do programa que até dezembro de 2013 não havia sido concluído. Para viabilizar a construção de sua unidade habitacional tiveram que aguardar até 2013, para poder acessar os recursos do Programa Minha Casa Minha vida Rural.

No levantamento de campo, registrou-se que algumas famílias vivem em barraco, pois acessaram o programa de moradia da $\mathrm{CEF}$, mas que diante da possibilidade vendeu 
o material e não terminou de construir a casa, além de ficar inadimplente. Quase todos os moradores do assentamento recebem recursos do programa Bolsa Família. São R\$ 70,00 por pessoa, valor descrito nos relatos, como representativo no orçamento.

Para ilustrar o percurso desde a entrada na luta pela terra citamos um exemplo a seguir:

Dona Neuza inscreveu-se para o processo de seleção de beneficiários em 1996. Dois anos depois, recebeu uma carta informando que seria assentada na região onde morava. De 1998 a 2000, esperou ser chamada para o assentamento. Como não foi, decidiu partir para o acampamento. Em 2003, foi assentada e enfrentou dificuldades na ao chegar no assentamento. Para ela, a mudança da realidade gerou expectativas que foram dizimadas na entrada do lote, pois não havia infraestrutura, e nem acesso a nenhum tipo de serviço num raio de $20 \mathrm{~km}$. O lote de D. Neuza localiza-se na antiga área onde estava o acampamento. Nesse momento, as fossas do acampamento, foram organizadas na margem de um dos córregos que cortam a fazenda, contaminando a água do lençol freático que aparece a 10/12m de profundidade. Ela até tem poço artesiano, mas como a contaminação alcançou o lençol freático o poço com água potável deve ter no mínimo $15 \mathrm{~m}$ de profundidade.

Na casa há uma televisão, uma geladeira com quase vinte anos, um fogão a gás e outro à lenha, um chuveiro elétrico no único banheiro da casa. Segundo ela, uma minoria dos moradores do assentamento tem carro. A casa tem em torno de $42 \mathrm{~m} 2$, e uma parte que está sendo ampliada. Tendo sido beneficiária do PMR, dona Neuza conta sua experiência, relatando dificuldades desde o projeto até a compra dos materiais. Os 40 sacos de cimento que dariam para construir a casa inteira foram entregues de uma vez, mas a entrega dos tijolos foi feita em duas etapas. A falta de lugar para estocar o cimento, e a demora na entrega 
dos tijolos da segunda etapa inviabilizaram a conclusão da casa; ela perdeu mais da metade dos sacos de cimento. Outro problema que enfrentou foi, que no lugar do vaso com caixa acoplada especificada no projeto, ela instalou uma válvula hidra. A equipe de engenharia da CEF que fez a vistoria não aprovou a instalação, bloqueando o seu contrato, uma vez que a casa deveria seguir o projeto aprovado. Por essas e outras razões, até hoje, nenhum beneficiário que contratou esse programa recebeu os recursos para adquirir os materiais para a última etapa, que inclui reboco externo e fossa séptica.

Para ela, viver no assentamento é uma guerra inglória, porque luta e sabe que não vai ter nada. Por isso, receber um valor por pessoa como o Bolsa Família ajuda a renda das famílias com $\mathrm{R} \$ 70,00 /$ pessoa. No assentamento não há correio e a conta de luz não chega; o assentado tem de ir ao escritório do INCRA em Iaras para pegar a conta e pagá-la no caixa do banco. O caminhão também não faz coleta; o lixo é queimado em buraco no chão do próprio lote, contaminando o solo. Embora tivesse acontecido uma mobilização para separar os recicláveis, não houve coleta.

Segundo os relatos, o assentamento também enfrenta problemas de prostituição: meninas novas se prostituem por $\mathrm{R} \$ 1,00$ ou por uma carteira de cigarros. Durante a ocupação dos lotes, ainda que a prestação se serviços e a presença de estabelecimentos comerciais não faça parte do projeto, sabe-se que no AZUP existem ao menos cinco bares, nos quais "o forrozão come solto". Foram registrados no levantamento a oferta de serviços de mecânico e até entrega de pizza no lote por $\mathrm{R} \$ 20,00$.

Pode-se considerar que 70\% dos assentados estão endividados: aqueles que acessaram os recursos da CEF para construir a casa estão em condições mais crítica do que aqueles que acabaram de entrar e ainda estão no barraco de lona. Em Iaras, com a possibilidade de 
novas áreas para o assentamento, será organizada uma fila de espera para o INCRA tenha um cadastro de famílias aptas a ocupar um lote quando houver desistência. Em 2013, foi feita uma mesa de seleção para 81 novos lotes no assentamento Zumbi dos Palmares; alguns casos será feita a regularização de famílias que já moram ali, e têm preferência, por alcançar a pontuação conforme a sistemática de classificação do INCRA que consta na N45/2005 (INCRA).

Em seu relato dona Neuza afirma que, para dar certo, a família tem de ter vocação, pois, mesmo que tenha capacidade de produzir, as dificuldades de escoamento (para onde levar) exigem criatividade, articulação e muita organização. É difícil conseguir cumprir todas as exigências, por exemplo, a produção de orgânico no assentamento não tem valor agregado, pois na cidade de Iaras não há quem certifique a produção. Além disso há o problema ambiental que inviabiliza o seu licenciamento.

D. Luzia foi procuradora que representava os beneficiários e era responsável por assinar as notas fiscais da aquisição de produtos de todas as famílias do programa de moradia da CEF. Vivendo no lote 96, teve dificuldade para produzir no pararrural. No sitio Recanto do Beija Flor, como não teve orientação plantou as mudas de eucalipto muito próximas; as árvores ficaram altas e com tronco fino, inviabilizando a comercialização, gerando prejuízos.

Dois dos mestres de obras, que atuaram na operação do PMR, estão trabalhando como pedreiros na construção da escola. Vieram respectivamente de São Paulo e do Rio de Janeiro onde trabalhavam na construção civil. Nos relatos afirmam que, mesmo diante das dificuldades, preferem morar no assentamento. Para Haroldo, 80\% das famílias que vivem no Zumbi, são de origem suburbana. Diz ele que $40 \%$ da condição extremamente 
precária em que vivem os assentados é culpa deles, para ele, muitas famílias ficam esperando mais créditos e não se organizam, que se acomodam. Muitos gastaram o PRONAF para comprar um carro velho que logo não conseguem tirar do lote, seja porque não passam na estrada, seja porque não conseguem dar conta da manutenção. Demonstrando os efeitos da falta de orientação técnica quando chegou ao assentamento, lembra-se de que, quando plantou arroz pela primeira vez, usou um saco de "Tio João" comprado no supermercado da cidade, adubou e esperou crescer. Depois de alguns meses, sem resultado, procurou um vizinho que o ensinou: o arroz para ser plantado tem que ter casca.

\subsubsection{Institucional: Equipamentos}

O Zumbi dos Palmares não tinha escola, começou a ser construída em 2013, até então a prefeitura disponibiliza ônibus para as crianças e jovens irem à cidade. No município não há cursos superior e caso algum assentado queira, precisa ir nas cidades vizinhas como Avaré ou Bauru. Há 15 jovens que fazem um curso técnico de agroecologia no município de Itapeva, moram na cidade e voltam periodicamente ao assentamento, dessa maneira, estão impossibilitados de produzir no lote ajudando os pais. Há também um assentado que faz o curso superior de geografia na Universidade Estadual
Foto 9: Posto de saúde da família

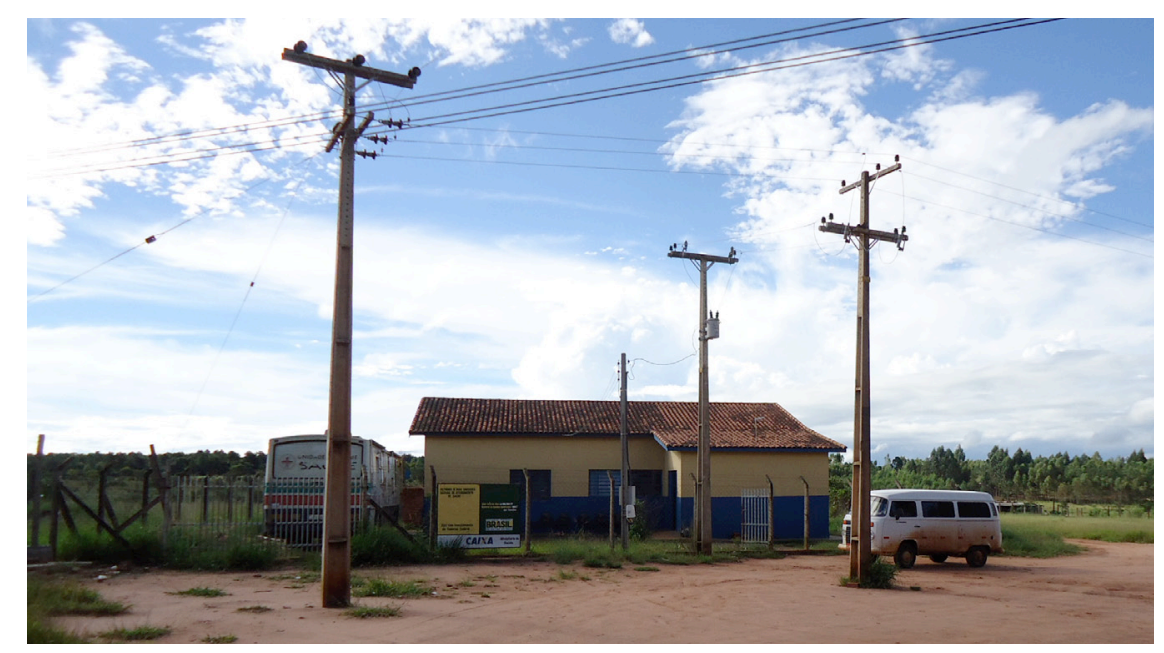

Fonte: foto registrada pela autora 
Paulista (UNESP) de Presidente Prudente, ele vai periodicamente, estuda por algumas semanas e depois volta para realizar o trabalho em seu lote. (ROMANO, 2009, p. 20).

Há um posto de saúde e o atendimento é diário, entretanto, o atendimento é feito somente pelo clínico geral, para casos mais simples (um machucado, um resfriado, etc.). Se o quadro do paciente for algo mais complexo ou que o médico não o identifique recomenda a ida do paciente ao posto da cidade de Iaras, onde possui maior infraestrutura. (ROMANO, 2009 P.19)

A Escola de Ensino Fundamental está em construção a três anos com recursos do governo do Estado via prefeitura, a mão de obra encarregada da obra são moradores do assentamento que antes viveram na periferia de São Paulo e do Rio de Janeiro, como outros, tem experiência na construção civil dos conjuntos habitacionais construídos durante os anos 90. Para eles, o posto de saúde funciona bem, tem médico todo dia.

O posto de saúde é a referência do assentamento ao lado está em construção a escola e em frente está o bar do Mauricio, uma casinha de madeira pintada de verde limão, lá dentro, nas prateleiras muitos tipos de doces, além de cerveja e cachaça.
Foto 10: Escola de Ensino Fundamental

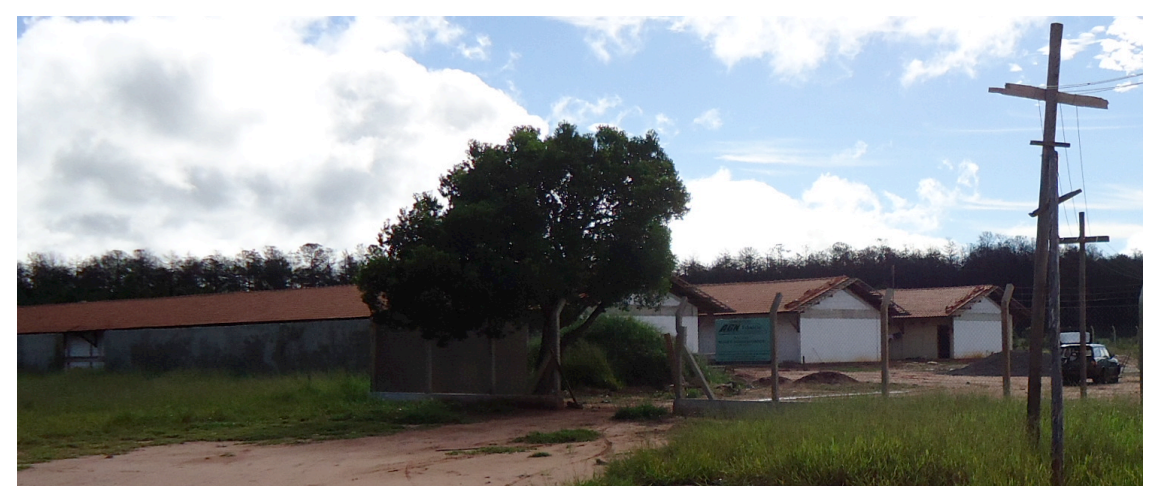

Fonte: foto registrada pela autora

Foto 11: Bar do Maurício

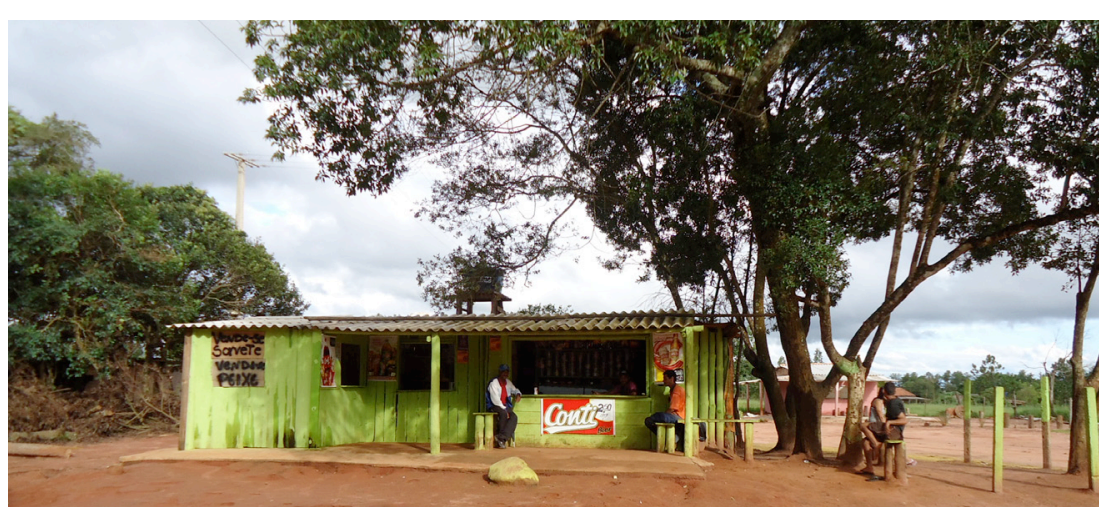

Fonte: foto registrada pela autora 


\subsubsection{Barracão}

A Associação tem um barracão mas não tem o documento de concessão de uso do lote onde está construído, por isso não conseguem acessar recursos à fundo perdido para reforma e ampliação das funções, agregando valor à produção, por exemplo com a limpeza e embalagem das hortaliças. Foi com a assistência técnica promovida pelos "japoneses" do IBS que os assentados aprenderam o cultivo de orgânicos, ainda não receberam o selo de reconhecimento do órgão responsável, pois o assentamento não têm LA, inviabilizando o aprimoramento, desenvolvimento das famílias produtoras.

Mesmo com a ajuda do governo aos grandes produtores, a agricultura familiar tem conseguido se manter na produção agropecuária com boas taxas sendo: $28 \%$ da produção total com somente $22 \%$ da terra e recebendo apenas $11 \%$ do crédito rural. Ou seja, os agricultores familiares com menos crédito e terra produzem mais que os grandes, o que prova um melhor aproveitamento da terra e do capital (FAO/INCRA, 1996 apud MARTINS, 2010).

O técnico que trabalha no escritório de Iaras desde 2008 afirma que o assentamento não dá certo pois a seleção de famílias não considera a experiência da família com o meio rural. A evasão é justificada pelo perfil das famílias assentadas, que nos últimos dez anos tem sido urbano, um tipo de família que está acostumado a receber salário todo mês, porém, quando entra no lote, enfrenta problemas diversos com os quais não está preparado para enfrentar (burocráticos e ambientais como geada que acaba com a plantação ou praga desconhecida).

"Se acaba o gás quem é do sítio vai para o fogão à lenha, quem é da cidade quer ir embora." (D. Neuza). 


\subsubsection{Permanência e continuidade}

A permanência no assentamento, para o técnico, é quase uma "seleção natural" que no Zumbi dos Palmares, teve início em 2000. A venda de lotes e a mudança na geração das famílias deu início pois, as pessoas que lutaram por esse assentamento entraram na terceira idade e já não tem forças para trabalhar no lote. Outro fator que interfere no sucesso do assentamento é a falta de capacidade operacional do INRCA. O fato de não ter gente suficiente para elaborar o Plano de Desenvolvimento do Assentamento - PDA faz com que as famílias entrem no lote sem um projeto de vida.

A problemática de organizar a produção, o que plantar e como fazer inclui as pragas, as variações climáticas e animais silvestres que também se alimentam do que é produzido no assentamento e tornam-se pragas como as lebres na produção do maracujá, ela come a raiz da planta e faz morrer toda a trepadeira antes de dar o fruto. Outros animais como onça suçuarana com filhote, veado campeiro, tamanduá, porco espinho, muitos passarinhos e muitas cobras como a sucuri, além de escorpiões.

No mercado irregular de lotes vendidos no assentamento, o para rural custa em torno de $\mathrm{R} \$ 5.000,00$, normalmente é comprado por famílias que vivem na cidade e querem ter um lugar para passar o final de semana, uma chácara, funcionários públicos no acampamento para ter lote. 


\section{Considerações}

O projeto e assentamento rural, sobretudo no interior paulista, revela-se instrumento de materialização das políticas públicas. Direcionadas por metas e objetivos estabelecidos em âmbito nacional, o programa de reforma agrária do país foi orientado por dois planos. Do ponto de vista da arquitetura, diferentemente da habitação, o projeto de assentamento rural é raro objeto de estudo. Tendo sido abordado nos diferentes âmbitos das ciências econômicas, agrárias e sociais, a materialização do ambiente construído no assentamento é caracterizada e reconhecida por frágeis condições de infraestrutura e saneamento. Prevista nos planos para ocorrer em até 20 anos, a trajetória entre a criação do projeto e sua emancipação superou a expectativa.

Conforme mencionado no primeiro capítulo, os dois planos nacionais promulgados até hoje estabeleceram metas que não puderam ser cumpridas, seja pela falta de interesse político, que dificulta a articulação entre as esferas governamentais, seja pela burocracia imposta pelas diretrizes dos programas: o formato de operação das políticas públicas de reforma agrária não considera as condições de parcelamento do assentamento - tamanho da área, dos lotes e a distância da cidade - dificultando o sucesso das famílias. No entanto, a pesquisa mostra que, do primeiro plano para o segundo, houve uma preocupação em relação às condições de vida dos assentados, um exemplo foi, em 2010, a lei de assistência técnica. Específica para os agricultores familiares dos assentamentos rurais, a lei obriga o acompanhamento especializado no assentamento, o que proporcionou alternativas para o atendimento. A presença do técnico em campo tem possibilitado melhor aproveitamento dos recursos disponíveis e consequentemente tem interferido positivamente na qualidade 
de vida das famílias, como visto nos relatos sobre a reorganização das associações para produzir.

O estudo da tipologia dos projetos implicou reconhecer que o assentamento é um lugar que se constrói a partir de uma reordenação e de um recomeço de vida. O projeto do parcelamento é a intenção de um lugar que irá se construir, a base na qual as famílias irão se reorganizar, começar uma nova etapa da vida. Primeiramente com seus barracos de lona, transportados do acampamento para o lote, a chegada ao assentamento é muito diferente do que imaginam os acampados. A casa, o abastecimento com água e luz, mesmo a fossa adequada para não contaminar o solo e a água, não estão previstas na proposta do projeto e normalmente demoram para serem executadas. Mesmo em condições muito precárias, desde o início, a materialização do assentamento traz impactos territoriais de escala e regional, ainda que os resultados da situação socioeconômica não sejam empolgantes. (ROVER; MITIDIERO, 2010).

Como visto, o levantamento dos tipos de parcelamento implantados em São Paulo mostrou que as especificidades de cada projeto determinam a opção da organização social. Isso pode ser identificado no desenho do projeto. O detalhamento das normas e das instruções técnicas considera uma série de variáveis para o projeto, por exemplo, a participação das famílias na definição do parcelamento. No entanto, diferentemente do que imaginado no início da pesquisa, na maioria das implantações paulistas as famílias são consultadas sobre o projeto de parcelamento; é por opção delas que os lotes são organizados como um tabuleiro de xadrez ou como uma espinha de peixe. Muitas vezes não é só a falta de capacidade operacional do setor público que inviabiliza o cumprimento de todas as etapas, prejudicando a implantação. 
Resultado de um processo moroso, originado de disputas judiciais, a participação das famílias na elaboração do projeto é restrita às experiências nas quais o grupo interessado se envolveu no desenho do projeto. Nos casos onde não há interesse por parte das famílias, é adotado o parcelamento ortogonal, do tipo xadrez. Foram verificadas pela pesquisa raras implantações diferenciadas pelo parcelamento do solo: são os PDS ou assentamentos implantados com diretrizes definidas pelo MST que resultam nas formas do tipo roda de carroça. Das poucas agrovilas que se verificam no Estado, pode-se dizer que resultaram das primeiras experiências de 1985.

A maioria dos projetos é do tipo xadrez ou espinha com o parcelamento de lotes individuais. O PDS é adotado pelo INCRA em São Paulo como alternativa para combater problemas diagnosticados ao longo dos anos: a evasão das famílias e a venda irregular de lotes.

No levantamento realizado os técnicos do INCRA indicaram que, muitas vezes, não conseguem cumprir todas etapas previstas para criar um projeto adequado, ou para que tenha o melhor aproveitamento da área, como por exemplo a organização dos lotes em agrovilas, que facilitariam a implantação de infraestrutura de abastecimento. A etapa de participação das famílias, por mais curta que seja, indica que têm sido comum a opção pelo parcelamento de lotes individuais. Na visita ao assentamento em 2013 verificou-se que há um movimento contrário ao que estava ocorrendo, ao menos no que diz respeito à produção. O lançamento dos programas de aquisição de alimentos, seja de âmbito nacional ou estadual, fez com que as famílias assentadas deixassem de resistir aos modos associativos, ao menos para produzir.

Em 2010, a inclusão do PDS como possibilidade de projeto a ser implantado em São 
Paulo da inicio a uma nova perspectiva no que toca a ausência do plano de desenvolvimento do assentamento (PDA). Ainda em minoria, este tipo de assentamento aponta uma alternativa para que entrada no lote seja mais organizada e estruturada diminuindo a evasão das famílias e a venda irregular de lote. As diretrizes de preservação do meio ambiente e de planejamento contida nas diretrizes de projeto implicam num detalhamento em relação às especificidades da área e do grupo minimizando os impactos da entrada no lote sem planejamento, como ocorre na maioria dos casos. Nessa linha entendemos como Marques (2000) que a construção do assentamento implica a construção do assentado, por isso a importância na elaboração de um projeto de assentamento.

O ponto de contato entre a política e a ação em campo - a materialização - é fator diferencial para o alcance das metas e dos resultados que expressem a viabilidade de sustentação e fixação das famílias nos assentamentos rurais. Enquanto forma de ocupação, os assentamentos, representam a espacialização de um processo presente no desenvolvimento do país nos últimos quase trinta anos.

A experiência com a construção das casas no assentamento Zumbi dos Palmares tomada como referencial para este trabalho - exemplifica a problemática condição dos assentamentos desde a criação até a materialização do ambiente construído. Além disso, a pesquisa toca na questão da habitação indicando possíveis caminhos para outras pesquisas.

Nos assentamentos paulistas, a habitação aparece no âmbito das políticas públicas, em 2006, com a experiência do programa de moradia rural. Diferentemente de outras experiências no país, em São Paulo as diretrizes operacionais tiveram início um ano após as contratações. Em 2013, a maioria das casas contratadas ainda não havia sido concluída imprimindo uma imagem de abandono e precariedade com casas sem cobertura, sem portas 
ou janelas. Lançado em 2009 o Programa Minha Casa Minha Vida Rural teve algumas diretrizes revisadas e em 2013, é disponibilizado pelo Governo Federal ao público dos assentamentos.

Durante o levantamento realizado, não foi possível registrar as experiências com o programa, pois não havia ainda contratações. As famílias que contrataram o programa de moradia rural em 2006 não poderão acessar esses recursos, a não conclusão da obra e consequentemente do contrato implicam o cadastro das famílias como mutuários inadimplentes da Caixa Econômica Federal.

A leitura do processo de criação do assentamento Zumbi dos Palmares e a organização das informações do levantamento de campo permitiu a definição de critérios que organizou a análise em busca de compreender a forma de espacialização de forma que se justificasse o tipo de parcelamento.

A composição das figuras com os dados primários e secundários permitiu espacializar o levantamento realizado ilustrando o burocrático processo de criação do projeto de assentamento rural.

Foi possível reconhecer as relações entre a origem da terra e os efeitos da falta de controle fundiário. O impacto dessa ausência é refletido no moroso processo de obtenção da terra, o que gera as diferentes resultantes de parcelamento com a ocupação da área em etapas. A complexidade observada na transição entre o projeto e a materialização do assentamento, principalmente a inclusão de novos usos, reforçam a necessidade e indicam de se aprofundar mais a discussão acerca do projeto de parcelamento do assentamento rural de reforma agrária. 


\section{Referências Bibliográficas}

ARRUDA, A. F. O espaço concebido e o espaço vivido da morada rural: políticas públicas x modo de vida camponês. 2007. s/p. Dissertação (Mestrado em Arquitetura e Urbanismo) Faculdade de arquitetura e urbanismo da Universidade de São Paulo, São Paulo, 2007.

BRASIL. Constituição da República Federativa do Brasil de 1988. Brasília, DF, 5 de outubro de 1988. Disponível em: <http://www.planalto.gov.br/ccivil_03/constituicao/constituicaocompilado.htm> Acesso em: 16 abr. 2011.

Lei n. ${ }^{\circ}$ 4.504, de 30 de novembro de 1964. Dispõe sobre o Estatuto da Terra, e dá outras providências. Diário Oficial União, Brasília, DF, 31 nov. 1964. Disponível em: <http:/ / www. planalto.gov.br/ccivil/leis/L4504.htm>. Acesso em: 30 maio. 2010.

.Lei N ${ }^{0}$ 12.188, de 11 de Janeiro de 2010 -Institui a Política Nacional de Assistência Técnica e Extensão Rural para a Agricultura Familiar e Reforma Agrária - PNATER e o Programa Nacional de Assistência Técnica e Extensão Rural na Agricultura Familiar e na Reforma Agrária - PRONATER, altera a Lei no 8.666, de 21 de junho de 1993, e dá outras providências. Diário Oficial da União, 12 jan. 2010. Disponível em:<http:/ / www.planalto.gov.br/ccivil_03/_Ato2007-2010/2010/Lei/L12188.htm>Acesso em: 14 mar. 2012.

Lei n. ${ }^{\circ} 8.629$, de 25 de fevereiro de 1993. Dispõe sobre a regulamentação dos dispositivos constitucionais relativos à reforma agrária, previstos no Capítulo III, Título VII, da Constituição Federal. Diário Oficial da União, 26 fev. 1993. Disponível em: <http:/ / www.planalto. gov.br/ccivil_03/leis/18629.htm> Acesso em: 14 mar. 2012. 
.Decreto no 91.766, de 10 de outubro de 1985. Aprova o Plano Nacional de Reforma Agrária - PNRA, e dá outras providências. Diário Oficial da União, Seção 1, p.14903, 11 out.1985, Disponível em: <http://www2.camara.leg.br/legin/fed/decret/1980-1987/decreto-9176610-outubro-1985-441738-publicacaooriginal-1-pe.html>Acesso em: 24 jun. 2011.

.II Plano Nacional de Reforma Agrária. 2005. Disponível em: < http:/ / sistemas.mda. gov.br/arquivos/PNRA_2004.pdf>. Acesso em: 24 jun. 2011.

BARONE, Luís Antônio, BOTTA, Vera Lúcia S. Ferrante. A Reforma Agrária Que Temos: conflitos e resistências na política de assentamentos em São Paulo. In: CONGRESSO BRASILEIRO DE SOCIOLOGIA, 15, Curitiba/PR, 2011. Anais Eletrônicos. Curitiba, 2011.

CAMPOS, Ana Cristina. Madeireira poderão explorar mais de $1 \mathrm{mi}$ de hectares na Amazônia. UOL Notícias. 03/09/2012. Disponível em: <http://noticias.uol.com.br/meio-ambiente/ ultimas-noticias/redacao/2013/09/03/madeireiras-poderao-explorar-mais-de-1-milhao-dehectares-da-amazonia.htm> Acesso em: 30 set. 2013.

DOSSIÊ QUESTÃO AGRÁRIA. I Censo da Reforma Agrária. Estudos Av., São Paulo, v. 11, n. 31, dez. 1997. Disponível em:<http://www.scielo.br/scielo.php?script=sci_ arttext\&pid=S0103-40141997000300002\&lng=en\&nrm=iso> Acesso em: 28 mar. 2012.

FERREIRA, Brancolina. Estratégias de intervenção do Estado em Áreas de assentamento: as políticas de assentamento do governo federal. In: MEDEIROS, Leonildes. et al (Orgs). Assentamentos Rurais: uma visão multidisciplinar. São Paulo: Editora UNESP, 1994.

FIPE - Fundação Instituto de Pesquisas Econômicas. Relatório Final. Elaboração de indicadores para o monitoramento e avaliação do desenvolvimento dos assentamentos: 2011. São 
Paulo: FIPE, 2011.

GOLDFARB, Yamila. A luta pela terra entre o campo e a cidade: as comunas da terra do MST, sua gestação, principais atores e desafios. 2007. s/ p. Dissertação (Mestrado em Geografia Humana). Faculdade de Filosofia Ciências e Letras da Universidade de São Paulo, São Paulo, 2007.

HEINEN, M. I. O Plano Nacional De Reforma Agrária Do Governo Lula -Antecedentes. O Plano. Possibilidades e limites de sua execução. Disponível em <http://xa.yimg.com/kq/ groups/17929366/1990100000/name/O+plano+nacional+de+reforma+agr\% C3\% A1ria+do+ governo+lula.pdf >. Acesso em: 24/03/2013.

INCRA - Instituto de Colonização e Reforma Agrária. Norma de Execução No $\mathbf{N}^{\text {45. de }} 25$ DE AGOSTO DE 2005. Dispõe sobre procedimentos para seleção de candidatos ao Programa Nacional de Reforma Agrária. Diário Oficial da União, 166, seção 1, p. 122, de 29 ago 2005. Disponível em: <http:/ / www.incra.gov.br/index.php/institucionall/legislacao--/atos-internos/normas-de-execucao/file/323-norma-de-execucao-n-45-25082005?start=40> Acesso em: 15 jun. 2012.

Crédito Instalação (1985) 12 dez. 2011. Disponível em: <http:/ / www.incra.gov.br/index.php/reforma-agraria-2/ projetos-e-programas-do-incra/credito-instalacao>. Acesso em: 18 mai. 2012.

.Roteiro de Operacionalização de obra. Moradias Rurais no Estado de São Paulo, INCRA Regional (08). MDA, 2006.

Terras públicas do Núcleo Colonial Monção serão transferidas ao Incra/SP. 2011. 09 
mai. 2011. Disponível em: <http://www.incra.gov.br/index.php/noticias-sala-de-imprensa/ noticias/1266-terras-publicas-do-nucleo-colonial-moncao-serao-transferidas-ao-incrasp $>$. Acesso em: 18 mai. 2012.

Justiça bloqueia matrícula de fazenda ocupada pela Cutrale em São Paulo. 15 jul. 2013.Disponível em: <http://www.incra.gov.br/index.php/noticias-sala-de-imprensa/ noticias/13284-justica-bloqueia-matricula-de-fazenda-ocupada-pela-cutrale-em-sao-paulo> Acesso em 20 jul. 2013.

ITESP _ Instituto de Terras do Estado de São Paulo "José Gomes da Silva." Sítios e situantes: planejamento territorial e cálculo do módulo para assentamentos rurais. $2^{\mathrm{a}}$ ed. São Paulo: ITESP. Editora Gráfica. 2000. (Caderno 8).

LEITE, S. et al. Impactos regionais da Reforma Agrária no Brasil: Aspectos políticos, econômicos e sociais. In: SEMINÁRIO SOBRE REFORMA AGRÁRIA E DESENVOLVIMENTO SUSTENTÁVEL Fortaleza, CE, 1998. Anais... Fortaleza, 1998. Disponível em<http:/ /www.nead. gov.br/portal/nead/arquivos/view/textos-digitais/Artigo/arquivo_27.pdf > Acesso em: 20 set. 2012.

MARQUES, M.I.M. De sem-terra a posseiro. 2000, s/p. Tese (Doutorado em Geografia) Faculdade Filosofia Ciências e Letras, Universidade de São Paulo, São Paulo. 2000.

MARICATO, E. A terra é um nó na sociedade brasileira. Revista Cultura. Petrópolis: Ed. Vozes, v.. 93 n 6, p. 07 a 22, 1999.

Brasil, Cidades: alternativas para a crise urbana. Editora Vozes, Petrópolis. 2001.

. O nó da terra. São Paulo. Revista Brasileira de Direito Ambiental, [S.1], v. 15, p. 191- 
196, 2008.

MARTINS, J. S. Reforma agrária: o impossível diálogo. São Paulo: EDUSP. 2000.

MARTINS, Daniel C. M. Aplicação da Ferramenta da Qualidade Servqual para Detecção de Erros na Prestação de Serviços do Instituto Nacional de Colonização e Reforma Agrária - Incra - aos Assentados da Reforma Agrária da Região de Iaras. 2010, s/p. Trabalho de Conclusão de Curso (Especialização em Ciências Contábeis) Faculdade de Ciências Contábeis e Administrativas de Avaré - FACCAA, Avaré. 2010.

SOUZA, F. S. et. al. Impacto socioeconômico da reforma agrária no município de Iaras. Monografia (Bacharelado em Geografia) Faculdade Sudoeste Paulista, 2007.

MEDEIROS, L. et. al. Assentamentos Rurais uma visão multidisciplinar. São Paulo: Editora UNESP. 1995.

MEDEIROS, L.; LEITE, S. Assentamentos Rurais: Mudança social e dinâmica regional. Rio de Janeiro: MAUAD, 2004.

MITIDIERO JUNIOR, M. A. Reforma Agrária No Brasil: Algumas Contribuições Sobre A Materialização Dos Assentamentos Rurais. Agrária, São Paulo, n.14, p.4-22, 2011. Disponível em: <http://www.revistas.usp.br/agraria/article/view/55794/59203> Acesso em: 14 set. 2012.

NAVARRO, Zander. O projeto-piloto “Cédula da Terra” - comentário sobre as condições sociais e político-institucionais de seu desenvolvimento recente. Disponível em: <http://www. nead.gov.br/portal/nead/arquivos/view/textos-digitais/Artigo/arquivo_90.pdf>. Acesso em 25 abr.2013. 
NOGUEIRA, Renata F. A organização sócio-espacial do assentamento Olga Benário. 2007, 63 f. Monografia (Bacharelado em Geografia). Universidade Federal de Viçosa, Viçosa, MG, 2007. Disponível em: <http://www.geo.ufv.br/docs/ monografias/2007SegundoSemestre/renataNogueira.pdf>Acesso em: 13 jun.2012.

NORDER, Luiz A. C. Políticas de Assentamento e Localidade: os desafios da reconstituição do trabalho rural no Brasil. [S.l.], Wageningen Universiteit, 2004

OLIVEIRA, Francisco de. O Estado e Urbano no Brasil. Revista Espaço e Debates, [S.1.], n. 6, 1982.

Crítica à Razão Dualista - O ornitorrinco. São Paulo: Boitempo. 2003.

PERES, Renata B.. Habitação Rural: discussões e diretrizes para políticas públicas, planejamentos e programas habitacionais.2003. s/p. Dissertação (Mestrado em Arquitetura e Urbanismo) Escola de Engenharia São Carlos da Universidade de São Carlos, São Carlos, 2003.

ROCHA, Herivelto F. Análise e mapeamento da implantação de assentamentos rurais e da luta pela terras no Brasil entre 1985 - 2008. 2009. s/p. Monografia (Bacharelado em Geografia). Universidade Estadual de São Paulo - UNESP, Presidente Prudente. 2009.

RODRIGUES, Isis. Características Demográficas da População Rural Paulista nos anos 80 e 90. Textos NEPO, 43, Campinas, Núcleo de Estudos de População / UNICAMP, 2002.

ROMANO, Erik. F. O Desenvolvimento do Assentamento Zumbi dos Palmares em Iaras - SP. As infraestruturas e o Planejamento, 2009. In: ENCONTRO NACIONAL DE GEOGRAFIA AGRÁRIA, 19, São Paulo, 2009a. Anais... Disponível em: <http:/ /www.geo- 
grafia.fflch.usp.br/inferior/laboratorios/agraria/Anais\%20XIXENGA/artigos/Fernandes_ER.pdf>. Acesso em 24 abr. 2013.

ROMANO, Erik. F. A relação campo-cidade a precariedade de infraestrutura nos assentamentos e a modernização do campo - o caso do assentamento Zumbi dos Palmares em iaras - sp. 2009b. In: ENCONTRO NACIONAL DE GEOGRAFIA AGRÁRIA, 19, São Paulo, 2009. Anais... Disponível em: http:// www.geografia.fflch.usp.br/inferior/laboratorios/ agraria/Anais\%20XIXENGA/artigos/Fernandes_ER.pdf. >Acesso em 09 mar.2013.

ROMANO, Erik F.; LUEDEMANNS, Maria da. A Relação Campo-Cidade no Assentamento Zumbi Dos Palmares em Iaras - SP. <http:/ / prope.unesp.br/xxi_cic/27_22824595809. pdf>. Acesso em 09 fev.2013.

ROVER, O. J.; MUNARINI, P. R. A política de habitação rural e o desenvolvimento da agricultura familiar. Revista Katálysis, Florianópolis, v. 13, n² , 2010

SAMORA, P. R. Projeto de Habitação em Favelas: Especificidades e parâmetros de qualidade. 2010, s/ p. Tese (Doutorado em Arquitetura e Urbanismo). Faculdade de Arquitetura e Urbanismo da Universidade de São Paulo, São Paulo, 2010.

SÃO PAULO. Lei Estadual no. 4.925, de 19 de dezembro de 1985 a. Dispõe sobre a alienação de terras públicas estaduais a rurícolas que as ocupem e explorem, e dá outras providências <http://www.al.sp.gov.br/repositorio/legislacao/lei/1985/lei-4925-19.12.1985. html>Acesso em: 22 abr. 2012

Lei Estadual n. 4.957, de 30 de dezembro de 1985b. Dispõe sobre planos públicos de valorização e aproveitamento dos recursos fundiários. Disponível em: < http:/ / www.pge. 
sp.gov.br/centrodeestudos/bibliotecavirtual/dh/volume\%20i/prolei4957.htm>. Acesso em 22 abr. 2012.

SECRETARIA NACIONAL DO MST. MST Lutas e Conquistas. Reforma Agrária: Por justiça social e soberania popular. $2^{\mathrm{a}}$ ed. 2010. Disponível em:< http://www.mst.org.br/ sites/default/files/MST\%20Lutas\%20e\%20Conquistas\%20PDF.pdf>. Acesso em: 28 set. 2012.

SILVA, Ligia Teresa Paludetto. Uma visão ambiental da gênese dos assentamentos rurais no estado de São Paulo: de Sumaré ao Pontal do Paranapanema. 2006, s/p. Dissertação (Mestrado em Arquitetura e Urbanismo) Faculdade de Arquitetura e Urbanismo da Universidade de São Paulo, São Paulo, 2006.

ZUQUIM, M. L. Os caminhos do rural. Uma questão agrária e ambiental. São Paulo: Senac. 2007.

O Lugar do Rural nos Planos Diretores Municipais. In: CONGRESSO LUSO-BRASILEIRO PARA PLANEJAMENTO URBANO, REGIONAL, INTEGRADO E SUSTENTÁVEL, 3, São Carlos. 2008. Anais...PLURIS, São Carlos, 2008.

Sites visitados:

- Câmara Interministerial de Segurança Alimentar e Nutricional. Plano Nacional de Segurança Alimentar e Nutricional: 2012/2015. Brasília, DF: <2011.http://www.mds. gov.br/segurancaalimentar/arquivos/LIVRO_PLANO_NACIONAL_CAISAN_FINAL.pdf>. Acesso em fev. 2013.

- Fundação Instituto de Terras do Estado de São Paulo (ITESP): http:/ / www.itesp. 
sp.gov.br>. Acesso em fev. 2013.

- Fundação Sistema Estadual de Análise de Dados (Seade): http://www.seade.gov. br (acessado em março de 2013).

- Instituto Brasileiro de Geografia e Estatística (IBGE): http:/ / www.ibge.gov.br (acessado em novembro de 2013).

- Instituto de Colonização e Reforma Agrária (INCRA): <http:/ / www.incra.gov.br>. Acesso em 19 nov./2012

- Ministério do Desenvolvimento Agrário (MDA): http://www.mda.gov.br>. Acesso em novembro de 2013.

- Ministério das Cidades: <http://www.cidades.gov.br/images/stories/ArquivosSNH/ArquivosPDF/Portarias/Portaria_406_02.09.2011.pdf > Acesso em nov. 2012.

- Ministério do Desenvolvimento Social e Combate à fome: http://www.mds.gov.br Acesso em novembro de 2013.

- Movimento dos Trabalhadores rurais Sem Terra (MST): http://www.mst.org.br (acessado em setembro de 2012).

- Revista Estopim, agosto 2004: Disponível em: <http://estopim.net/y7/?p=2183>. Acesso em setembro de 2012. 